\title{
REESTRUTURAÇÃO DO SISTEMA DE PAGAMENTOS BRASILEIRO: O CASO DA CLEARING DE CÂMBIO DA BM\&F
}

DOUGLAS MIRANDA LIMA

\begin{abstract}
Dissertação apresentada à Escola Superior de Agricultura "Luiz de Queiroz", Universidade de São Paulo, para obtenção do título de Mestre em Ciências, Área de Concentração: Economia Aplicada.
\end{abstract}

PIRACICABA

Estado de São Paulo - Brasil

Novembro - 2002 


\title{
REESTRUTURAÇÃO DO SISTEMA DE PAGAMENTOS BRASILEIRO: O CASO DA CLEARING DE CÂMBIO DA BM\&F
}

\author{
DOUGLAS MIRANDA LIMA
}

Bacharel em Ciências Econômicas

Orientador: Prof. Dr. PEDRO CARVALHO DE MELLO

\author{
Dissertação apresentada à Escola Superior \\ de Agricultura "Luiz de Queiroz", \\ Universidade de São Paulo, para obtenção \\ do título de Mestre em Ciências, Área de \\ Concentração: Economia Aplicada.
}

PIRACICABA

Estado de São Paulo - Brasil

Novembro - 2002 
Dados Internacionais de Catalogação na Publicação (CIP)

DIVISÃO DE BIBLIOTECA E DOCUMENTAÇÃO - ESALQ/USP

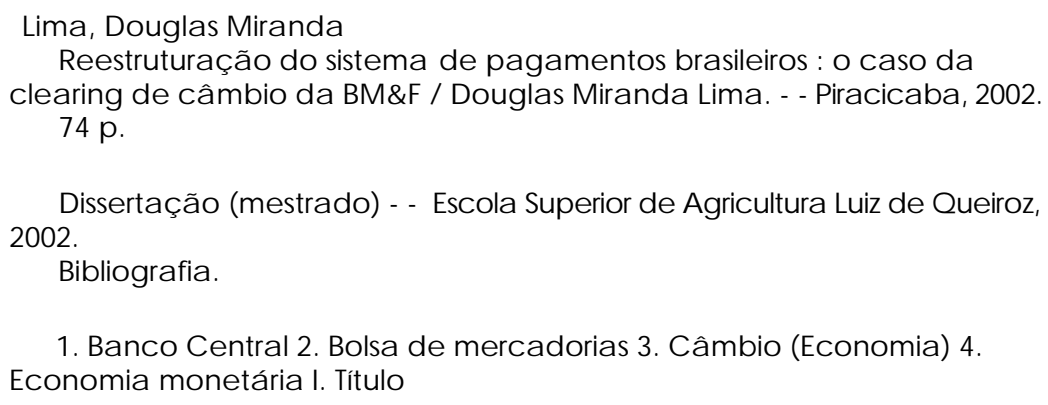

CDD 332.4

\section{"Permitida a cópia total ou parcial deste documento, desde que citada a fonte - 0 autor"}


Aos meus pais,

Rafael de Souza Lima e Maria Assunção Lima DEDICO

Aos meus irmãos,

Denner, Débora e ao

meu sobrinho Gabriel

OFEREÇO

A DEUS,

AGRADEÇO por mais esta oportunidade. 


\section{AGRADECIMENTOS}

Ao Prof. Dr. Pedro Carvalho de Mello pela amizade, orientação e principalmente pela confiança em mim depositada.

Aos Profs. Alexandre Mendonça de Barros, Pedro Valentim Marques e Sílvia Helena Galvão de Miranda pela atenção, interesse e dedicação dispensados durante a elaboração deste trabalho.

Ao Dr. Isney Manoel Rodrigues, Diretor da Clearing de Câmbio da BM\&F, e toda a sua equipe, por disponibilizarem dados e informações indispensáveis a este estudo.

Ao Dr. Luiz Fernando Figueiredo, Diretor de Política Monetária do Banco Central do Brasil, por não medir esforços na implantação do Novo Sistema de Pagamentos Brasileiro, o grande motivador dessa pesquisa.

À Prof ${ }^{a}$. e grande amiga Zilda Paes de Barros Matos, por toda tranquilidade que me passou durante a monitoria e nos momentos difíceis do curso.

Aos demais profs. do Departamento de Economia, Administração e Sociologia da ESALQ, por todo o ensinamento compartilhado.

Aos funcionários do Departamento de Economia, Administração e Sociologia da ESALQ, em especial àMaielli, por toda a ajuda e atenção.

A todos os amigos que encontrei nesse mestrado e, em especial, aos amigos da república “Deus Quis” pela ótima convivência no decorrer do curso.

A todos vocês, meu MUITO OBRIGADO. 


\section{SUMÁRIO}

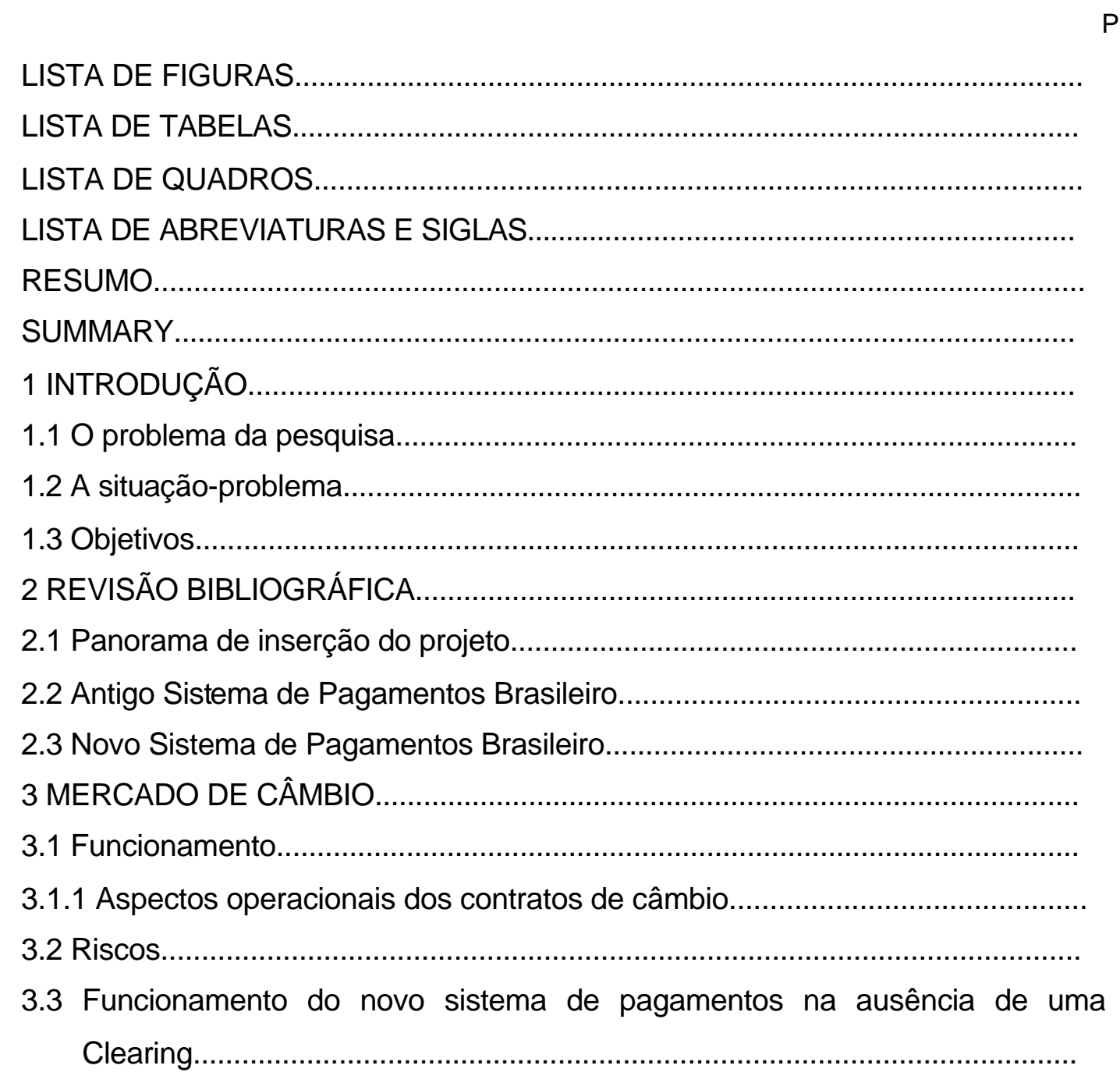

Página

vii

ix

$\mathrm{X}$

xi

xiii

XV

3.4 Comparação dos modelos de Clearing de câmbio existentes.

3.4.1 $1^{\circ}$ Modelo: Fluxo.

3.4.2 2 Modelo: Com chamadas de garantias, mas com repartição de perdas entre participantes. 
3.4.3 30 Modelo: Com chamadas de garantias, mas com repartição de perdas entre os participantes que operaram com inadimplentes.............................. 38

3.5 Projeto de Clearing de câmbio da BM\&F..................................................... 39

4 METODOLOGIA.............................................................................. 42

4.1 Análise qualitativa................................................................................ 44

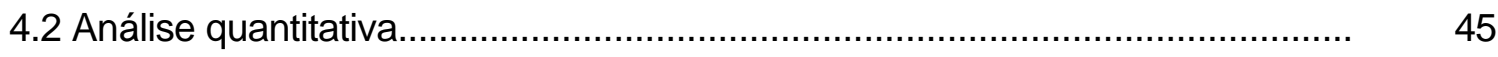

4.3 Dados........................................................................................ 46

5 RESULTADOS E DISCUSSÃO................................................................ 47

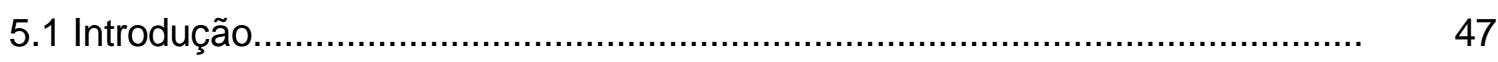

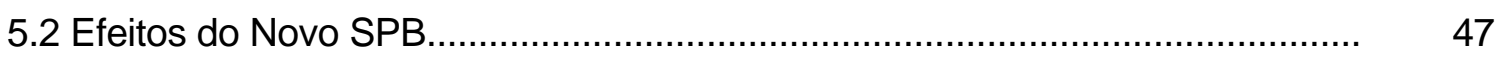

5.3 Clearing de Câmbio: Seu papel no novo SPB............................................... 51

5.4 Banco Central e Clearing de Câmbio............................................................ 55

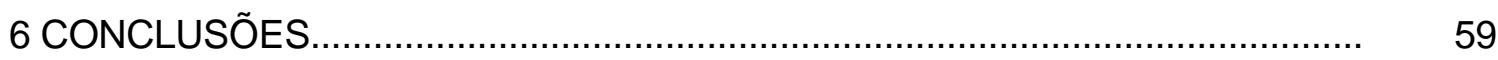

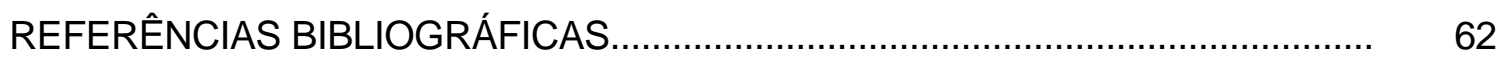

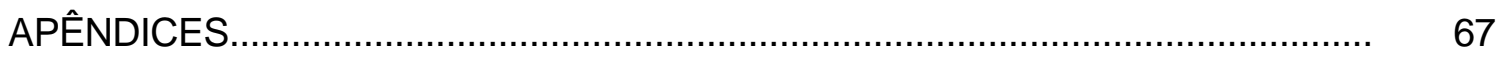




\section{LISTA DE FIGURAS}

Página

1 Total de garantias depositadas na Clearing de Câmbio em 30/09/2002.......... 10

2 Total de Fundo de Participação formado pela Clearing de Câmbio em

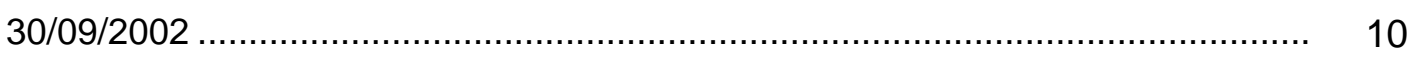

3 Liquidação no antigo Sistema de Pagamentos Brasileiro.................................. 13

4 Liquidação no novo Sistema de Pagamentos Brasileiro.................................. 16

5 Mercado de Câmbio Brasileiro....................................................................... 29

6 Contratação e Registro no Sisbacen............................................................ 30

7 Liquidação da moeda nacional e estrangeira................................................. 32

8 Evolução do Mercado de Câmbio Primário Comercial no período de jan/2001 a jul/2002

9 Evolução do Mercado de Câmbio Primário Financeiro no período de jan/2001 a jul/2002 …….................................................................. 49

10 Evolução do Mercado Interbancário de Câmbio no período de jan/2001 a

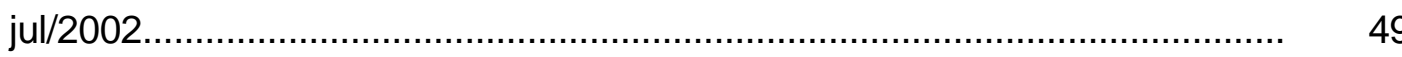

11 Total de giro, pagamentos e transferências via TED realizadas pelo STR entre 22/04/2002 e 30/09/2002 .............................................................. 50

12 Volume total do giro e dos pagamentos realizados pelo STR entre 22/04/2002 e 30/09/2002.

13 Volume contratado pela BM\&F para liquidação em $D+1$ no período de 22/04/2002 e 30/09/2002. 
14 Volume contratado pela BM\&F para liquidação em $D+2$ no período de 22/04/2002 e 30/09/2002

15 Volume financeiro mensal liquidado pela Clearing de câmbio entre maio e setembro de 2002.

16 Volume total do mercado interbancário de câmbio negociado no Sisbacen e na BM\&F para liquidação em D+1 no período de 22/04/2002 a $30 / 09 / 2002$

17 Volume total do mercado interbancário de câmbio negociado no Sisbacen e na BM\&F para liquidação em D+2 no período de 22/04/2002 a 30/09/2002.

18 Participação da Clearing no mercado interbancário de câmbio no período de 26/04/2002 a 30/09/2002. 


\section{LISTA DE TABELAS}

Página

1 Quantidade de documentos trocados no sistema financeiro brasileiro (em milhões de unidades).

2 Valor dos documentos trocados no sistema financeiro brasileiro (em $\mathrm{R} \$$ bilhões).

3 Características do antigo Sistema de Pagamentos Brasileiro.

4 Valores das tarifas bancárias cobradas por vários bancos para as operações de DOC e TED realizadas pelas pessoas físicas............................

5 Valores das tarifas bancárias cobradas por vários bancos para as operações de DOC e TED realizadas pelas pessoas jurídicas.

6 Mudanças para as pessoas jurídicas com o novo SPB 


\section{LISTA DE QUADROS}

Página

1 STR: Aspectos Operacionais das Transferências de Reservas..................... 18

2 Diferenças entre os sistemas de liquidação interbancárias............................ 20

3 Média de cheques e DOC entre fevereiro e agosto de 2001 .......................... 21

4 Mudanças para as pessoas físicas com o novo SPB..................................... 22 


\section{LISTA DE ABREVIATURAS E SIGLAS}

\begin{tabular}{ll} 
BACEN & Banco Central do Brasil \\
BIS & Bank for International Settlements \\
BM\&F & Bolsa de Mercadorias e Futuros \\
CBLC & Câmara Brasileira de Liquidação e Custódia \\
CETIP & Central de Custódia e de Liquidação Financeira de Títulos \\
CHIPS & Clearing House Interbank Payment System \\
CIP & Câmara Interbancária de Pagamentos \\
DEBAN & Departamento de Operações bancárias \\
DNS & Designated-time net settlement \\
DOC & Documento de Crédito \\
DVP & Delivery versus payment \\
FEBRABAN & Federação Brasileira dos Bancos \\
FEDWIRE & Federal Reserve Wire Transfer Service \\
FMI & Fundo Monetário Internacional \\
IF & Instituição Financeira \\
LBTR & Liquidação bruta em tempo real \\
LDL & Liquidação diferida líquida \\
PCP & Pagamento contra pagamento \\
PROER & Programa de Estímulo à Reestruturação e Fortalecimento do Sistema \\
& Financeiro Nacional \\
PROES & Programa de Incentivo à Redução do Setor Público Estadual na \\
PVP & Atividade bancária \\
RTGS & Payment versus payment \\
SELIC & Real-time gross settlement \\
& Sistema Especial de Liquidação e Custódia \\
& \\
\hline
\end{tabular}


SFN Sistema Financeiro Nacional

SISBACEN Sistema de Informações do Banco Central

SLC Superintendência de Liquidação e Custódia

SPB Sistema de Pagamentos Brasileiro

STR Sistema de Transferência de Reservas

SWIFT Society for Worldwide Interbank Financial Telecommunication

TED Transferência Eletrônica Disponível 


\title{
REESTRUTURAÇÃO DO SISTEMA DE PAGAMENTOS BRASILEIRO: O CASO DA CLEARING DE CÂMBIO DA BM\&F
}

\author{
Autor: DOUGLAS MIRANDA LIMA \\ Orientador: Prof. Dr. PEDRO CARVALHO DE MELLO
}

\section{RESUMO}

Este estudo teve como finalidade mostrar a importância da Clearing de Câmbio dentro do novo projeto de reestruturação do Sistema de Pagamentos Brasileiro. Para tanto foi observado como funcionava o antigo sistema, com os riscos assumidos pelo Banco Central, principalmente no que se refere àpossibilidade do risco sistêmico. No novo projeto, as Clearings são fundamentais para se evitar esse tipo de risco. Os dados utilizados permitiram que fossem feitas simulações com a presença ou não da Clearing. Para contextualizar o cenário em que se encontrava a economia antes da implantação do novo sistema fez-se uma breve análise do cenário de instabilidade pelo qual o sistema bancário atravessava e a forma como o governo conseguiu controlá-lo. Para garantir uma maior segurança em todo o sistema de pagamentos criou-se o Sistema de Transferência de Reservas adotando o processo de liquidação bruta em tempo real, conseguindo eliminar a possibilidade de risco de crédito. A Clearing de Câmbio possui um papel fundamental no novo SPB pois trabalha adotando o princípio da liquidação líquida, reduzindo a necessidade de capital para a realização das transações financeiras. $O$ objetivo do trabalho foi mostrar os efeitos causados no mercado de câmbio e o papel da clearing nesse novo sistema. Notou-se que o 
mercado interbancário de câmbio tem apresentado um grande equilíbrio não só entre o número de contratos de compra e venda de moeda, mas também entre o valor desses contratos. Os dados obtidos mostraram uma tendência de aumento no total de giro e de pagamentos realizados via STR. A Clearing tem mostrado cada vez mais uma grande importância no novo SPB, com um volume de contratos crescente tanto para liquidação em $\mathrm{D}+1$ quanto em $\mathrm{D}+2$. Verifica-se que nos primeiros cinco meses de existência apenas $15 \%$ de toda moeda negociada foi efetivamente transferida entre as instituições, reduzindo de forma considerável o montante de moeda necessária nas negociações e em conseqüência a possibilidade do risco sistêmico. Apesar da diminuição do tempo necessário para as transferências e da certeza de liquidação financeira, um dos principais problemas que ainda dificultam o aumento nas negociações através da Clearing de Câmbio são os altos custos para se operar nesse sistema. Para consolidar ainda mais a Clearing como instituição, estuda-se o lançamento de novos produtos que venham atender àdemanda do mercado financeiro, como por exemplo a possibilidade de liquidação financeira intradia e a negociação com outras moedas. A Clearing de Câmbio da BM\&F é a primeira do mundo a negociar moeda e o seu sucesso pode fazer com que instituições do mesmo gênero sejam criadas pelos Bancos Centrais dos outros países. 


\title{
BRAZILIAN PAYMENT SYSTEM RESTRUCTURING: THE CASE OF THE BM\&F FOREIGN EXCHANGE CLEARINGHOUSE
}

\author{
Author: DOUGLAS MIRANDA LIMA \\ Adviser: Prof. Dr. PEDRO CARVALHO DE MELLO
}

\section{SUMMARY}

This study had the goal to clarify the importance of the Foreign Exchange Clearinghouse related with the new project of restructuring the Brazilian System of Payments (BSP). With this purpose it was observed how the old payment system operated, with the risks assumed by the Central Bank, mainly those associated with the systemic risk. In the new project, the Clearinghouses have a fundamental role to avoid the systemic risk. The data used in the research allowed to simulate and compare the effects on the foreign exchange market, in the presence or in the absence of the Clearinghouse. To understand how the economy was before the implantation of the new project, it was done a brief analysis about the instability which the bank system was affected and the way that the government tried to control it. To guarantee more security in the whole payment system, it was created the Reserve Transfer System (RTS) that adopt a process of Real-Time Gross Settlement, achieving the goal of eliminating the possibility of credit risk. The Foreign Exchange Clearinghouse has a fundamental role in the new BSP because works adopting the principle of the net settlement, reducing the capital necessity to do financial transactions. A qualitative analysis had a purpose to show the effects due in the foreign exchange market and the 
Clearinghouse function in this new system. It was observed that the interbank foreign exchange market has been showed a great equilibrium in the number of contracts bought and sold, but also in their values. The data obtained presented a trend of raising in the total negotiated and in the payments done via RTS. The Clearinghouse has been showed that its importance is increasing in the new BSP, with the volume of contracts raising in both settlement $\mathrm{D}+1$ and $\mathrm{D}+2$. It is noted that in the first five months of existence, only $15 \%$ of whole currency negotiated was effectively transfered within institutions, reducing in a considerable manner the total of currency required and, in consequence, reducing the possibility of systemic risk. Although the diminishing of the time for transferences and of the certainty about the financial settlement, one of the main problems are the high costs to operate in this system. To consolidate the Clearinghouse importance as an institution, it has been done studies to launch new products to take care of the demand like, as example, the possibility of financial settlement intraday and the negotiation with other currencies. The BM\&F Exchange Clearinghouse is the first one in the world that transacts currency and its success may influence other countries that can adopt the same system. 


\section{INTRODUÇÃO}

De acordo com Banco Central do Brasil - BACEN (2001a), por sistema de pagamentos entende-se o conjunto de procedimentos, regras, instrumentos e sistemas operacionais integrados utilizados para a transferência de fundos do comprador para o vendedor, encerrando, assim, uma obrigação. Toda economia de mercado depende desses sistemas para movimentar os fundos decorrentes da atividade econômica (financeira, comercial e produtiva), tanto em moeda local quanto em moeda estrangeira.

Os sistemas de pagamentos são responsáveis por interligar, por meio de uma cadeia não coordenada de ordens de pagamentos, os agentes não-bancários, os bancos ${ }^{1}$ e o BACEN. O montante das transferências diárias dessas ordens (exceto as transações com papel-moeda), realizadas por meio de cheques, cartões de crédito, transferência eletrônica de fundos, documento de crédito, transforma-se em poucas transferências interbancárias de fundos de elevado valor nas contas reservas bancárias mantidas pelos bancos no BACEN. A conseqüência dessas transferências é o desequilíbrio do fluxo de caixa dos bancos nas reservas bancárias, criando a condição para o funcionamento do mercado interbancário de reservas, cujas transações também são realizadas via sistema de pagamentos.

Com o objetivo de aumentar a eficiência e melhorar a gerência de risco são feitas mudanças nos sistemas de pagamentos. Quanto ao aumento da eficiência busca-se um melhor fornecimento de serviços de pagamentos adequados às necessidades dos agentes, à minimização da flutuação (float) gerada pela defasagem entre a contratação e a liquidação dos pagamentos e à busca da redução de custos.

\footnotetext{
${ }^{1}$ Consideram-se bancos as instituições financeiras que mantêm conta Reservas Bancárias no BACEN. Por reservas bancárias entendem-se os depósitos em espécie que os bancos mantêm no BACEN tanto para fins de cumprimento de recolhimento compulsório, quanto para efetuar pagamentos interbancários.
} 
Como resultado espera-se um melhor desempenho das atividades econômicas suportadas por tais sistemas.

Para melhorar a gerência de riscos são criados mecanismos que reduzem a possibilidade de perdas enquanto o pagamento ainda não finalizou, ou seja, antes da transferência efetiva de fundos entre as contas reservas bancárias dos bancos envolvidos e a transferência do bem, serviço ou ativo negociado. A estabilidade dos mercados financeiros depende fortemente desse ponto, pois a rede na qual o sistema de pagamentos opera é um meio potencial de transmissão de distúrbios.

A relação entre os bancos é muito grande, de forma que o pagamento de um banco representa a liquidez de outro, de modo que qualquer distúrbio na transferência de fundos, independente do motivo, pode levar àinadimplência de outros agentes, que deles dependiam para equilibrar seus caixas. Assim, mesmo as instituições financeiras que não estão diretamente envolvidas com o banco inadimplente podem ser afetadas. Esses distúrbios na cadeia de pagamentos (sem a existência de mecanismo de proteção), abalam a confiança e a discricionariedade de todo o sistema financeiro, afetando a concessão de crédito, especialmente o interbancário. Se essa inadimplência local não for contida, todo o sistema financeiro é desestabilizado.

Todo o sistema de pagamentos é elaborado para poder suportar a quebra de um ou mais participantes. Caso não existam mecanismos adequados para o controle do risco, o BACEN se torna refém do risco sistêmico, pois ele acaba sendo o órgão que assume os riscos produzidos pelos demais participantes ${ }^{2}$.

O BACEN, para amenizar esses riscos, se defronta com a seguinte questão: devolver os lançamentos a descoberto na conta reservas bancárias, aceitando as possíveis conseqüências, ar fornecer liquidez mesmo que a saque a descoberto, dando curso àcadeia de pagamentos. Qualquer que seja a decisão tomada, problemas surgirão.

\footnotetext{
${ }^{2}$ As razões para se explicar a falha da contraparte podem ser de natureza técnica ou temporária. Ou seja, o evento pode ser caracterizado como "transação insuficiente", em vez de "falta de pagamento". Muitas vezes, na data de liquidação, os fatores que podem vir a levar àfalha de uma das partes nem sempre são bem identificados. Em conseqüência, pode-se abalar a confiança das instituições em seus parceiros de negócios. Essa ruptura das condições de perfeita liquidação de qualquer uma das partes pode provocar uma reação em cadeia, que poderá impactar a saúde financeira de outras instituições, afetando a confiança na solvência do sistema, com sérias conseqüências sobre os mecanismos de financiamento à produção. Segundo Bank for International Settlements - BIS (2002c) a combinação dos efeitos dessas categorias pode levar ao chamado risco sistêmico. Uma definição precisa desse tipo de risco é dada por BACEN (2000b): "a probabilidade de falhas de crédito e/ou de liquidez que venham a deflagrar uma reação em cadeia envolvendo os participantes de um sistema".
} 
Adotando a primeira solução, o BACEN apenas transferirá os problemas de inadimplência de um participante para o outro. Se adotar a segunda solução evitam-se problemas sistêmicos no curto prazo; no entanto, num segundo momento, elimina-se $o$ incentivo dos bancos de se introduzir controles próprios de proteção contra a falta de pagamentos tornando-se mais agressivos e assumindo maiores riscos em seu negócio. Segundo BACEN (2001a), o Banco Central do Brasil se defronta com esse dilema e para tentar amenizá-lo propôs o projeto de reestruturação do sistema de pagamentos brasileiro.

\subsection{O problema da pesquisa}

Dentro do novo sistema de pagamentos proposto pelo BACEN um dos objetivos é repassar o controle do mercado de câmbio para uma Câmara de Compensação. Criou-se então a Câmara de Registro, Compensação e Liquidação de Operações de Câmbio BM\&F (Clearing de câmbio) para deixar as operações no mercado interbancário de câmbio mais seguras. Essa clearing se responsabiliza pelo cumprimento dos contratos interbancários de câmbio evitando que a inadimplência de alguma instituição financeira venha a gerar problemas para o BACEN e para o mercado financeiro, assumindo parte dos riscos causados por essa inadimplência.

A proposta desta dissertação é avaliar quais os efeitos causados no mercado de câmbio com a implantação do novo Sistema de Pagamentos Brasileiro (SPB). Particularmente pretende-se verificar qual o papel da Clearing de Câmbio da Bolsa de Mercadorias e Futuros (BM\&F) dentro desse novo sistema, analisando a participação dessa Clearing junto ao BACEN.

\subsection{A situação-problema}

O antigo sistema de pagamentos brasileiro foi desenvolvido, ao longo das últimas décadas, em meio a um ambiente de forte desequilíbrio macroeconômico e com o objetivo principal de aumentar a eficiência. Houve uma redução do tempo de compensação de cheques e outros papéis e o desenvolvimento de diversos sistemas operacionais para liquidação e custódia eletrônica de títulos. Na época em que esse 
sistema foi instalado as prioridades associadas àestruturação destes sistemas eram a agilidade e a segurança das operações.

Entretanto, a partir da segunda metade dos anos 90, com o Brasil já inserido no processo de globalização, ocorreu um fato decisivo que marcou profundamente a transformação na economia brasileira: o processo de estabilização (a partir do Plano Real). Como conseqüência, houve uma reestruturação do setor financeiro (PROER e PROES) despertando o debate para a importância da redução do risco individual e sistêmico.

Sob a ótica da experiência internacional três grandes questões vêm norteando as discussões sobre 0 desenho dos modelos voltados para este objetivo, principalmente após as crises financeiras que abalaram o mundo: supervisão bancária, regulamentação prudencial ${ }^{3}$ e sistema de pagamentos. No caso brasileiro, o BACEN coordenou diversos avanços em termos de regulamentação prudencial e lançou, em 1999, as bases para o debate a respeito do assunto.

O projeto anunciado estabeleceu as diretrizes para o funcionamento de um novo sistema de pagamentos no Brasil. Segundo elas, esse novo sistema funciona baseado em três formas diferentes de liquidação dos pagamentos interbancários, que convivem juntas e se diferenciam pelo montante liquidado e pelo sistema de liquidação utilizado. Essas três formas são: o Sistema de Transferência de Reservas (STR) - que liquida grandes valores), as Clearings (baseadas no princípio de liquidação pelo total líquido de operações ao final do dia) e a compensação tradicional (que não modificou o seu funcionamento e ainda pode ser utilizado para liquidação).

De acordo com BACEN (2000a) a implantação do novo Sistema de Pagamentos Brasileiro ocorreu em 22 de abril de 2002. A partir desse dia, o mercado passou a contar com mecanismos que evitam que o mesmo fique travado em razão do aumento excessivo da demanda por reservas bancárias, que eventualmente possa ocorrer.

Uma das bases para o sucesso desse novo sistema é a presença das Clearings. Elas foram elaboradas para garantir o fiel cumprimento de todos os negócios realizados nas bolsas e de acordo com Bolsa de Mercadorias \& Futuros -

\footnotetext{
${ }^{3}$ Por regulamentação prudencial entende-se todas as normas e regulamentos estabelecidos pelo BACEN que visem estabelecer uma normalidade no sistema financeiro evitando distúrbios.
} 
BM\&F (1996), esse sistema pode ser tanto um departamento interno como uma organização independente, controlada ou não pela bolsa.

Para o BIS (2002a) essa distinção depende de quem possui e opera o sistema e não da identidade do agente de liquidação. Sendo assim, existem sistemas do BACEN, pertencentes a este banco e operados por ele (ou por suas entidades afiliadas) nos quais o BACEN também se encarrega da liquidação; e sistemas do setor privado, pertencentes a um grupo privado e operados por ele (seja uma associação bancária ou uma câmara de compensação) onde o papel operacional principal do BACEN é o de agente de liquidação.

$\mathrm{Na}$ Bolsa de Mercadorias e Futuros - BM\&F - os serviços de Clearing são prestados por um departamento interno, a Superintendência de Liquidação e Custódia (SLC), responsável pelo registro das operações e controle de posições, compensação de ajustes diários, liquidação financeira e física dos negócios e administração de garantias.

De acordo com BM\&F (2001a), as câmaras de compensação existentes no Brasil não possuíam instrumentos para o controle de riscos, ficando para o BACEN o papel de banco inadimplente (dentro da cadeia de pagamentos), assumindo todo 0 risco existente nos contratos. O BACEN concedia crédito sem limite (via saque a descoberto em reservas bancárias), sem garantias e sem contrato para que os bancos pudessem saldar suas dívidas e ao mesmo tempo evitassem o risco sistêmico.

Dentro do novo sistema de pagamentos proposto, as Clearings (divididas em Clearings de pagamentos, de ativos, de derivativos e de câmbio) mostram-se fundamentais para evitar esse risco sistêmico.

Dentre todas essas Clearings, este trabalho analisará a de câmbio pois esta contempla um dos mais importantes mercados, tomado como referência para se analisar a economia de qualquer país. O mercado de câmbio possui enorme importância pois nele são movimentados os fluxos cambiais originários do sistema financeiro e comercial. Além disso ele envolve o setor produtivo e o mercado financeiro, ligando o mercado doméstico e o externo.

Até o início do ano de 2002, as operações de câmbio eram realizadas através do Sistema de Informação do Banco Central (Sisbacen) e o pagamento/recebimento dos reais correspondentes à contratação de determinada operação era feito mediante débito/crédito nas contas de reservas bancárias. A liquidação geralmente acontecia 
após decorridos dois dias úteis ( $\mathrm{D}+2)$ pelo valor bruto (uma a uma). Neste antigo modelo não estavam envolvidos os depósitos de garantias e não existia sincronia entre a efetivação dos pagamentos, de forma que as instituições compradoras ou vendedoras corriam riscos nas respectivas operações.

O volume movimentado no mercado de câmbio brasileiro gira em torno de US $\$ 2$ bilhões por dia (PROPOSTA, 2000b) e a existência de uma Clearing que o regulamente e o controle ajuda a diminuir o risco sistêmico, fortalecendo, em consequência, o sistema financeiro nacional.

\subsection{Objetivos}

O objetivo desta dissertação é avaliar, do ponto de vista qualitativo, quais os efeitos causados no mercado de câmbio com a implantação do novo Sistema de Pagamentos Brasileiro (SPB). Particularmente pretende-se verificar qual o papel da Clearing de Câmbio da BM\&F dentro desse novo sistema, analisando a participação dessa Clearing junto ao BACEN e sua eficiência na redução do risco sistêmico da economia brasileira.

As variáveis observadas e medidas ao longo do trabalho procuram mostrar não só a evolução do novo SPB mas também a importância da Clearing de Câmbio nesse novo sistema. A participação dos agentes (comercial, financeiro e o BACEN) no SPB, a evolução do Sistema de Transferência de Reservas (STR), os volumes contratados pela BM\&F para liquidação em D+1 e D+2 e os volumes liquidados pela Clearing de Câmbio são algumas dessas variáveis.

Além desta introdução, o presente trabalho conta com mais 5 capítulos. Uma breve caracterização do atual sistema de pagamentos, da evolução do setor bancário e da nova proposta do BACEN é feita no capítulo 2. O terceiro capítulo descreve o funcionamento do mercado de câmbio, mostrando os seus riscos e a atuação da Clearing de câmbio da BM\&F.

O quarto capítulo descreve a metodologia a ser utilizada para se alcançar os objetivos propostos. No capítulo 5 são apresentados e discutidos os resultados e por último, no capítulo 6 são apresentadas as conclusões e as recomendações finais. 


\section{REVISÃO BIBLIOGRÁFICA}

\subsection{Panorama de inserção do projeto}

Há cerca de vinte anos, o Brasil terminou um ciclo de crescimento econômico que se iniciou nas primeiras décadas do século e que foi caracterizado pela implantação de uma base industrial, ampla e diversificada, para produzir bens que antes eram importados. O papel desempenhado pelo Estado foi muito importante, atuando como empresário, por meio das empresas estatais, criando os mecanismos e incentivos para atrair o capital estrangeiro e transferindo renda para financiar o capital doméstico, privado e estatal.

Com o fim do modelo de substituição de importações o Estado entrou numa grande crise fiscal, com o esgotamento de sua capacidade de poupar, em virtude das pressões de diferentes grupos da sociedade pelo controle de fatias do bolo das despesas governamentais, que excediam aquilo que o Estado era capaz de obter através da receita tributária tradicional e de sua capacidade normal de endividamento.

Essas pressões foram aumentando e o Brasil entrou na década de 90 com uma das mais instáveis economias até então já vistas, com uma inflação que chegou a 2.708\% no ano de 1993 (Instituto Brasileiro de Geografia e Estatística - IBGE, 2001).

O cenário de instabilidade se altera após 1994, com a implantação do Plano Real. A proposta deste plano era conseguir uma estabilidade financeira por meio do combate àinflação, a qual foi alcançada, pois em 1995 a inflação atingiu 14,8\% (IBGE, 2001). Com essa queda na inflação e consequente estabilização da moeda foram retirados os ganhos inflacionários (floating) das instituições financeiras, enfraquecendo diversas dessas instituições. Ocorreu um crescimento das insolvências bancárias e a necessidade de se reformular todo o sistema financeiro passou a ser urgente, pois 
algumas instituições bancárias (como o Banco Econômico, o Banco Meridional e o Banco Nacional) começaram a passar por problemas.

Esses problemas foram solucionados com o emprego de recursos do PROER (Programa de Estímulo à Reestruturação e Fortalecimento do Sistema Financeiro Nacional) e do PROES (Programa de Incentivo à Redução do Setor Público Estadual na Atividade Bancária).

O PROER consumiu, em valores da época, cerca de $R \$ 17$ bilhões (BACEN, 2002a) e de acordo com Fortuna (1999) seu objetivo era assegurar a liquidez e a solvência do sistema, possibilitando ao governo administrar as instituições com problemas até que elas pudessem ser saneadas e repassadas a outros grupos. Ainda em 1995 o governo dificultou a constituição de novas instituições financeiras e criou incentivos para a fusão, incorporação e transferência de controle acionário.

O PROES foi criado em moldes semelhantes ao PROER e oferecia três alternativas à instituições bancárias: privatização com incentivos financeiros do governo, transformação em banco de fomento com ajuda do governo ou continuar na mesma situação. A estimativa de gastos para esse programa foi bem maior que o do PROER, de acordo com Fortuna (1999), algo em torno de $R \$ 54$ bilhões em valores da época.

Tanto o PROER quanto o PROES tinham como papel garantir a calma e a estabilidade do sistema financeiro nacional, assegurando os baixos índices inflacionários, que poderiam ser revertidos caso o dinheiro depositado nas instituições fosse jogado no sistema. Esses depósitos apresentam um valor bem maior do que aquele efetivamente depositado nas instituições devido ao mecanismo do multiplicador bancário que os bancos possuem.

Em tese, somente o BACEN pode emitir moeda, mas os bancos também tem esse poder. A moeda produzida pelos bancos recebe o nome de moeda escritural e ao seu processo de criação dá-se o nome de multiplicador bancário. O mecanismo de funcionamento deste sistema está descrito de modo simplificado a seguir.

Do ponto de vista do banqueiro, os diversos depósitos realizados pelas pessoas e empresas nos bancos geram empréstimos; mas do ponto de vista do sistema bancário como um todo os empréstimos que o banco concede às pessoas e empresas geram depósitos. O segredo, segundo Simonsen \& Cysne (1995) está em que o banco não empresta realmente o dinheiro que tem em caixa, mas sim, faz um promessa de 
que este papel-moeda estará disponível para o cliente se ele achar necessário, o que, como todos sabem (inclusive o banco) raramente acontece. Após o depósito e o redepósito, o banco está novamente apto a reiniciar o processo.

O dinheiro que o banco emprestou permanece no seu caixa, pronto para ser utilizado. No entanto, o montante que o banco pode novamente emprestar é menor que o inicial. O motivo e o percentual desta redução depende da primeira transação realizada. Parte do dinheiro que o primeiro cliente solicitou pode ter sido usado para pequenas despesas (aquelas feitas sem a utilização de cheques), resgatando uma fração do empréstimo. Para satisfazer essa demanda, os bancos precisam manter em caixa um percentual dos depósitos que aceita, ao qual dá-se o nome de reserva voluntária. O BACEN, por sua vez, considerando esse percentual insuficiente para garantir a segurança do sistema decide impor um coeficiente adicional de reservas, ao qual dá-se o nome de reservas compulsórias (servem para cobrir as retiradas naqueles dias em que estas excederem o coeficiente normal, para o qual o banco está preparado voluntariamente).

O mecanismo de funcionamento das clearings é semelhante ao do sistema bancário, ou seja, elas fazem com que o valor movimentado pelos bancos seja bem maior que o montante realmente depositado em seus caixas. Segundo BM\&F (2002a) os mecanismos de salvaguardas financeiras (dispositivos de segurança que garantem a liquidação das operações aceitas pelas clearings) são formados pelas garantias (feitas pelos bancos), pelos fundos (feitos pela clearing) e pelo patrimônio especial (feito pela bolsa). A figura 1 mostra a diversificação dos títulos aceitos como garantias pela clearing de câmbio da BM\&F. O montante total dessas garantias no dia 30/09/2002 era $R \$ 953.591 .947,59$ (BM\&F, 2002b), enquanto o montante dos fundos de participação dessa clearing, para esta mesma data, valia $R \$$ 94.751.319. Observando a figura 2 verifica-se os diversos títulos que formam as garantias. Os principais são as Notas do Banco Central (NBCE), seguido pelas Notas do Tesouro Nacional (NTN) e pelas Letras Financeiras do Tesouro (LFT). Juntos, esses três títulos são responsáveis por aproximadamente $85 \%$ de todas as garantias depositadas na Clearing de Câmbio. 


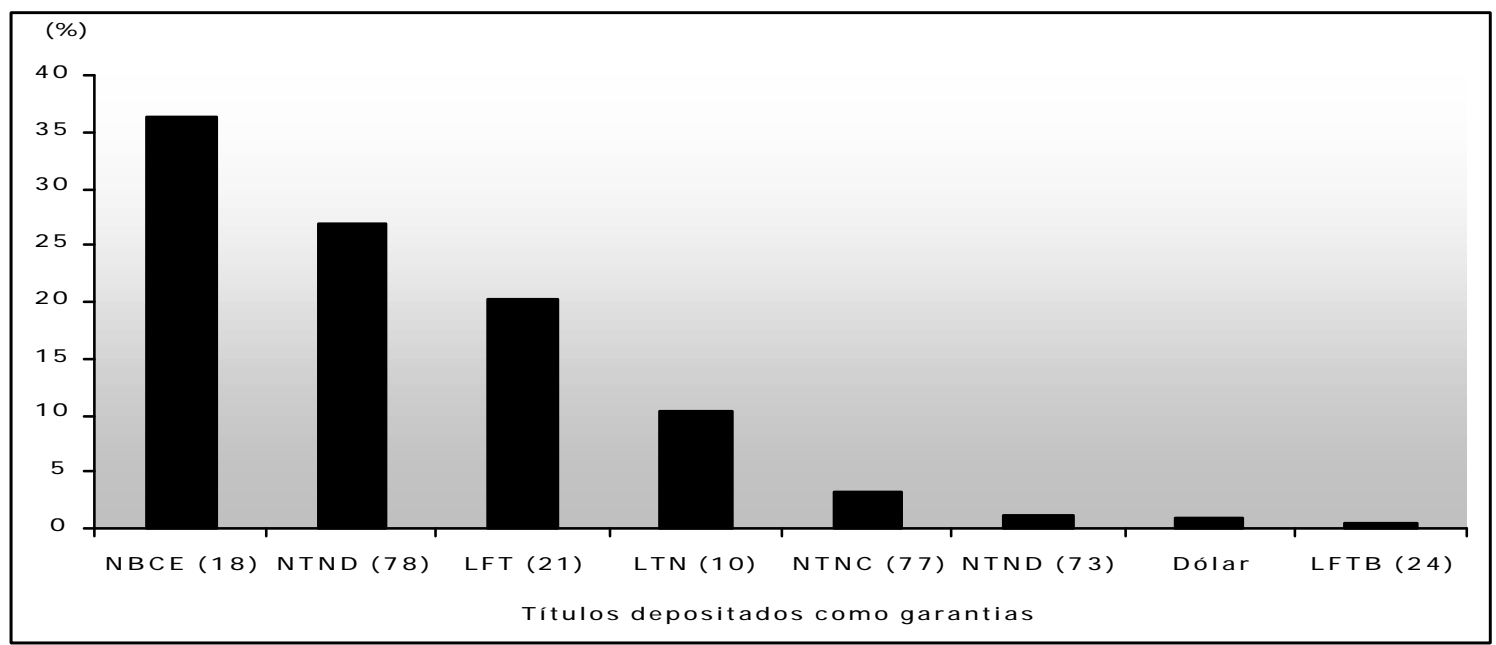

Figura 1 - Total de garantias depositadas na Clearing de Câmbio em 30/09/2002.

Fonte: BM\&F (2002b)

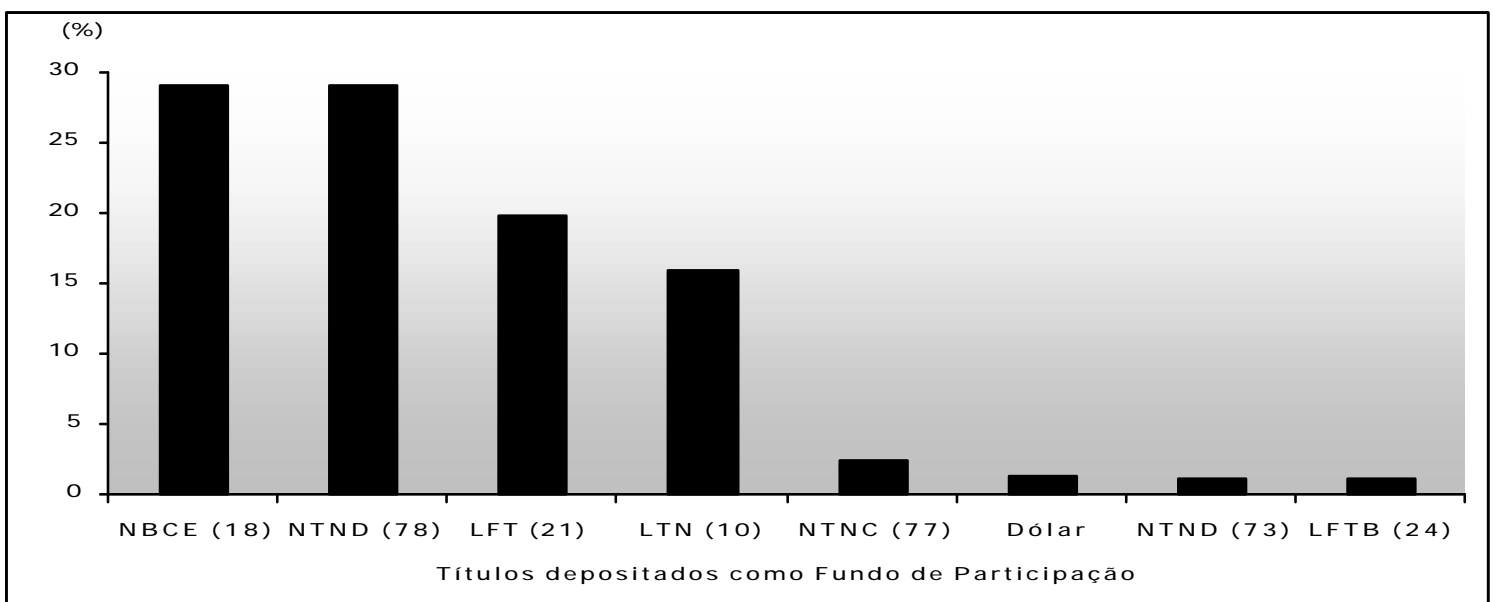

Figura 2 - Total de Fundo de Participação formado pela Clearing de Câmbio em 30/09/2002.

Fonte: BM\&F (2002b)

Junto com a consolidação do sistema bancário ocorreu um crescimento da quantidade de cheques, Documentos de Crédito (DOCs) e cobranças que circulam no mercado e são utilizados para a aquisição diária de bens de consumo e serviços. Esse consumo diário é representado pelas compras que as pessoas fazem, pelos pagamentos realizados e pelas transferências de dinheiro entre as contas. Nos últimos anos a quantidade de documentos trocados e o volume de moeda transacionado têm 
aumentado, exigindo maior controle de todo o sistema financeiro, com treinamento de funcionários e modernização da infra-estrutura bancária, evitando-se com isso que o sistema venha a entrar em colapso.

De acordo com a tabela 1, nos últimos 5 anos foram trocados no Brasil uma média anual de 2,7 bilhões de cheques, 580 milhões de bloquetos de cobrança e mais de 60 milhões de Documentos de Crédito (DOCs).

Essas trocas, segundo o tabela 2, chegaram a corresponder a um volume anual superior a $R \$ 4$ trilhões, sendo mais de $R \$ 1,82$ trilhões em cheques, $R \$ 450$ bilhões em bloquetos de cobrança e $R \$ 1,76$ trilhões em DOCs.

Tabela 1. Quantidade de documentos trocados no sistema financeiro brasileiro (em milhões de unidades).

\begin{tabular}{lccccccc}
\hline \multicolumn{7}{c}{ Composição da troca } \\
\hline \multirow{2}{*}{ Período } & \multicolumn{3}{c}{ Documento } & & Total & \multicolumn{3}{c}{ Participação \% no Total } \\
\cline { 2 - 3 } & Cheque (A) & $\begin{array}{c}\text { Bloqueto de } \\
\text { Cobrança (B) }\end{array}$ & DOC (C) & (A+B+C) & Cheque & $\begin{array}{c}\text { Bloqueto de } \\
\text { Cobrança }\end{array}$ & DOC \\
\hline 1997 & $2.943,9$ & 512,6 & 44,2 & $3.500,6$ & 84,1 & 14,6 & 1,3 \\
1998 & $2.751,5$ & 545,7 & 49,8 & $3.347,0$ & 82,2 & 16,3 & 1,5 \\
1999 & $2.612,1$ & 565,6 & 58,6 & $3.236,3$ & 80,7 & 17,5 & 1,8 \\
2000 & $2.637,5$ & 624,4 & 70,1 & $3.332,0$ & 79,2 & 18,7 & 2,1 \\
2001 & 2.600 .3 & 681,5 & 82,2 & $3.364,1$ & 77,3 & 20,3 & 2,4 \\
\hline
\end{tabular}

Fonte: BACEN (2002a)

Tabela 2. Valor dos documentos trocados no sistema financeiro brasileiro (em R $\$$ bilhões).

\begin{tabular}{llcccccc}
\hline \multicolumn{7}{c}{ Composição da troca } \\
\hline \multirow{2}{*}{ Período } & \multicolumn{3}{c}{ Documento } & \multirow{3}{c}{ Total } & \multicolumn{3}{c}{ Participação \% no Total } \\
\cline { 2 - 3 } & Cheque (A) & $\begin{array}{c}\text { Bloqueto de } \\
\text { Cobrança (B) }\end{array}$ & DOC (C) & (A+B+C) & Cheque & $\begin{array}{c}\text { Bloqueto de } \\
\text { Cobrança }\end{array}$ & DOC \\
\hline 1997 & $1.860,4$ & 351,7 & $1.676,1$ & $3.888,3$ & 47,8 & 9,0 & 43,1 \\
1998 & $1.797,4$ & 367,3 & $2.031,7$ & $4.196,4$ & 42,8 & 8,8 & 48,4 \\
1999 & $1.741,0$ & 421,3 & $1.859,0$ & $4.021,3$ & 43,3 & 10,5 & 46,2 \\
2000 & $1.805,8$ & 514,6 & $1.390,5$ & $3.710,8$ & 48,7 & 13,9 & 37,5 \\
2001 & $1.884,9$ & 595,4 & $1.849,7$ & $4.330,1$ & 43,5 & 13,8 & 42,7 \\
\hline
\end{tabular}

Fonte: BACEN (2002a) 
Um novo sistema de pagamentos que trouxesse mais segurança para todo esse fluxo de ativos (dinheiro, cheques, DOCs, fundos, etc.) se tornou urgente no Brasil, para reduzir os riscos e aumentar a confiança no sistema financeiro.

\subsection{Antigo Sistema de Pagamentos Brasileiro}

Segundo Andrezo \& Lima (1999), o antigo Sistema de Pagamentos Brasileiro era composto por quatro câmaras de compensação: Selic, Cetip, Compe e Câmbio que liquidavam as operações diretamente nas reservas bancárias do BACEN. Algumas características dessas Clearings são dadas a seguir.

O Selic (Sistema Especial de Liquidação e Custódia) era o sistema responsável pelas transações, primárias e secundárias, com títulos públicos federais, sendo esses títulos desmaterializados (isto é, escriturais e custodiados em nome de seus possuidores). A Cetip (Central de Custódia e de Liquidação Financeira de Títulos) destinava-se a negociar os títulos privados e alguns títulos públicos. Nesse antigo sistema, tanto o Selic quanto a Cetip liquidavam suas operações através do saldo líquido multilateral ao final do período ( $\mathrm{D}+0$ para o Selic e $\mathrm{D}+1$ para a Cetip). $\mathrm{A}$ transferência era feita operação a operação, enquanto a liquidação financeira era realizada pelo valor líquido por instituição.

A Compe é o sistema responsável pela compensação de cheques e outros papéis, enquanto o sistema de câmbio é aquele no qual são realizadas as transações interbancárias com moeda estrangeira.

Em nenhuma dessas Clearings existia um mecanismo que gerenciasse os riscos e que fosse capaz de absorver a insolvência de um de seus participantes. As mensagens de liquidação financeira que elas enviavam ao BACEN não eram criticadas quanto a saldo, o que permitia a manutenção de saques a descoberto na conta Reservas Bancárias ao longo do dia, sem garantias e sem contrato, como mostrado na figura 3.

Os principais tipos de risco assumidos pelo BACEN nesse sistema eram o risco de crédito e o risco de liquidez. O risco de crédito, definido como o grau de incerteza de uma das partes de uma operação sobre o integral cumprimento da obrigação contratual por sua contraparte, efetivava-se caso o banco não regularizasse seu caixa até o final do dia, e em geral, estava associado àinsolvência da contraparte. Já o risco 
de liquidez define-se como o grau de incerteza de uma das partes de uma operação sobre o tempestivo cumprimento da obrigação contratual por sua contraparte e decorre da impossibilidade momentânea de cumprimento de uma obrigação financeira.

Dependendo da intensidade com que esses riscos afetam o mercado, pode ocorrer o risco sistêmico. Esse risco é definido como a probabilidade de falhas de crédito ou de liquidez que venham a deflagrar uma reação em cadeia envolvendo os participantes de um sistema. Nesse caso, devido àinterligação e interdependência de direitos e obrigações, a inadimplência de uma instituição ocasiona uma sucessão de inadimplências em outras instituições, que pode levar, em casos extremos, ao comprometimento da estabilidade dos mercados e até à ruptura do sistema como um todo. A importância do risco sistêmico, portanto, é maior nos sistemas de pagamentos interbancários ${ }^{7}$, nos quais a maior parte dos pagamentos é de grandes valores.

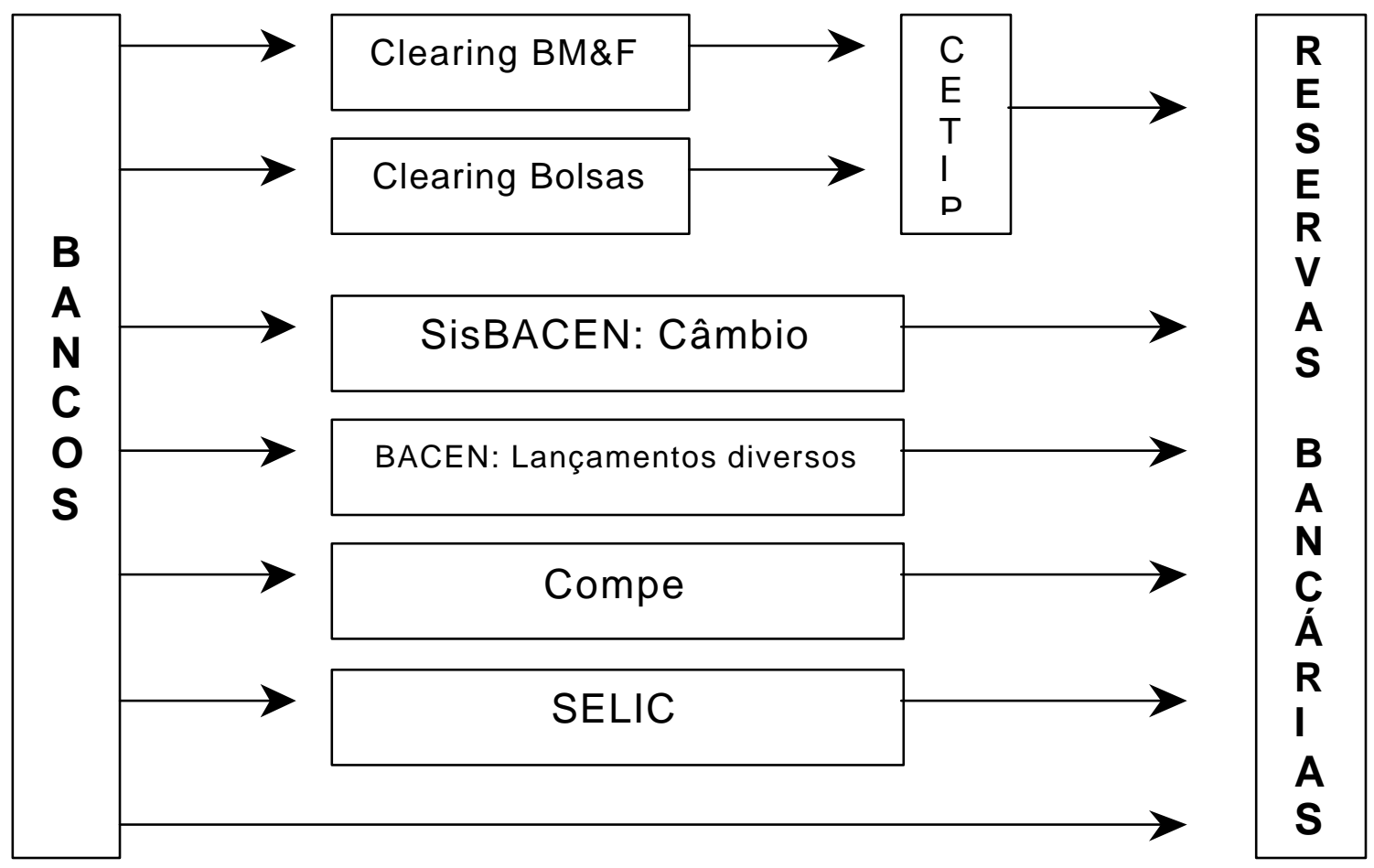

Figura 3 - Liquidação no antigo Sistema de Pagamentos Brasileiro.

Fonte: Elaboração do autor

\footnotetext{
${ }^{7}$ Os fluxos financeiros na economia podem ser intrabancários (quando o pagador e o recebedor possuem relação de conta corrente no mesmo banco) ou interbancários (quando os agentes têm conta em bancos diferentes).
} 
De acordo com Chakravorti (1996) esse antigo sistema de pagamentos colocava o BACEN em uma posição complicada. Como as câmaras de compensação não dispunham de mecanismos para administrar riscos, o BACEN evitava devolver as ordens de liquidação em reservas bancárias dos participantes com saldo insuficiente. Por outro lado, essa suposição de certeza de liquidação sob a qual operava o sistema financeiro, garantida pelo aumento de risco de crédito do BACEN, criava sérios problemas, tornando os bancos mais relaxados em suas avaliações dos riscos envolvidos nos sistemas e contrapartes com que eles operavam.

No entanto, como se pode ver na tabela 3, esse antigo sistema de pagamentos possuía alguns aspectos positivos. Existia uma ampla automação dos processos (o que reduzia o tempo de processamento), os títulos negociados eram todos desmaterializados (permitindo um sistema de custódia eletrônica ágil e de menor custo), a base tecnológica de telecomunicações atendia plenamente às necessidades e as câmaras de compensação já existiam e operacionalmente funcionavam de modo adequado.

Tabela 3. Características do antigo Sistema de Pagamentos Brasileiro.

\begin{tabular}{|c|c|c|}
\hline \multicolumn{3}{|c|}{ POSITIVAS } \\
\hline $1-$ & $\begin{array}{l}\text { Ampla automação dos processos, } 1- \\
\text { reduzindo o tempo de processamento. }\end{array}$ & $\begin{array}{l}\text { O BACEN assumia os riscos produzidos pelos } \\
\text { demais participantes, elevando o potencial de } \\
\text { risco sistêmico. }\end{array}$ \\
\hline $2-$ & $\begin{array}{l}\text { Os títulos negociados eram todos } 2- \\
\text { desmaterializados, permitindo um sistema } \\
\text { de custódia eletrônica mais ágil e de } \\
\text { menor custo. }\end{array}$ & $\begin{array}{l}\text { Como as regras de absorção de risco pelo } \\
\text { BACEN não estavam escritas, não era } \\
\text { possível mensurar claramente, na ótica do } \\
\text { investidor externo, os riscos envolvido nas } \\
\text { aplicações financeiras no Brasil. }\end{array}$ \\
\hline $3-$ & $\begin{array}{l}\text { A base tecnológica de telecomunicações } 3- \\
\text { atendia plenamente às necessidades do } \\
\text { sistema. }\end{array}$ & $\begin{array}{l}\text { As câmaras de compensação não possuíam } \\
\text { mecanismos de proteção que assegurassem a } \\
\text { liquidação de todas as operações, na hipótese } \\
\text { de quebra de um participante. }\end{array}$ \\
\hline $4-$ & $\begin{array}{l}\text { As câmaras de compensação já existiam } 4 \text { - } \\
\text { e operacionalmente funcionavam de } \\
\text { modo adequado. }\end{array}$ & $\begin{array}{l}\text { Existia um elevado intervalo de tempo para a } \\
\text { liquidação nas Bolsas, reduzindo sua } \\
\text { competitividade internacional na atração de } \\
\text { investidores externos. }\end{array}$ \\
\hline
\end{tabular}

Fonte: Elaboração do autor 
No entanto, essa antiga configuração também possuía sérios problemas. O principal ocorria quando o BACEN assumia os riscos produzidos pelos demais participantes, induzindo à suposição de liquidação financeira certa (isso elevava o potencial de risco sistêmico). Existiam também reflexos sobre os investidores externos, pois como as regras de absorção de risco pelo BACEN não estavam escritas, não era possível mensurar claramente, na ótica do investidor externo, o risco envolvido nas aplicações financeiras no Brasil.

Um outro problema presente era o fato das câmaras de compensação não possuírem mecanismos de proteção capazes de assegurar o cumprimento de todas as operações na hipótese de quebra de um participante. Para que isso não ocorresse havia a necessidade de melhorias na base legal para reconhecimento da compensação multilateral, abrindo espaço para processos de novação ${ }^{8}$ assim como as garantias constituídas pelos participantes na Clearing que, para tornar efetivos os mecanismos de proteção, deveriam ser passíveis de execução sem qualquer impedimento, na hipótese de inadimplência de um participante. Por último, tinha-se um elevado intervalo de tempo para a liquidação nas Bolsas, reduzindo sua competitividade internacional na atração de investidores externos.

Todos esses problemas foram fortes motivadores para a reestruturação do Sistema de Pagamentos Brasileiro, e juntamente com o mercado, o BACEN tentou resolvê-los, contribuindo para maior estabilidade e segurança do sistema financeiro do Brasil.

\subsection{Novo Sistema de Pagamentos Brasileiro}

O BACEN aprovou, na Reunião da Diretoria de 30 de julho de 1999, o "Projeto de Reestruturação do Sistema de Pagamentos Brasileiro ", expondo e detalhando as diretrizes adotadas. O objetivo geral desse novo sistema é diminuir os riscos do sistema financeiro (risco sistêmico) assumidos pelo BACEN.

A implementação desse novo sistema gerou três mudanças fundamentais para a movimentação de recursos no setor financeiro: a criação, pelo BACEN, de um mecanismo de transferência de fluxos interfinanceiros de grandes valores; a adaptação

\footnotetext{
${ }^{8}$ Novação é o mecanismo contratual por intermédio do qual as Clearings podem se interpor como responsáveis por assegurar a finalização de uma transação entre duas partes.(Sandroni, 1994)
} 
de outros sistemas que envolvam movimentação de recursos e, consequentemente, adequação das Clearings (nas quais são registradas e liquidadas as negociações com papéis e outros ativos financeiros) e a constituição de uma base legal sólida para dar sustentação ao funcionamento dessas entidades.

Para que o objetivo de redução do risco sistêmico fosse alcançado, várias medidas passaram a ser adotadas. Entre elas tem-se: os sistemas de liquidação financeira e negociação passaram a ser concretizados em tempo real, com liquidação bruta de operação por operação, via Sistema de Transferência de Reservas (STR), ou com liquidação líquida pelo total de operações ao final do dia, via Clearing ou ainda pelo sistema de compensação tradicional; monitoramento rigoroso, em tempo real, do saldo da conta Reservas Bancárias (não sendo mais permitido saldo negativo); estabelecimento de linhas de redesconto intradia e overnight, mediante operações compromissadas com títulos federais e garantia de integração dos diversos sistemas (internos e externos ao BACEN) que têm liquidação final na conta Reservas Bancárias.

Nesse novo modelo para o SPB, o fluxo de lançamento nas reservas bancárias ocorre como mostrado na figura 4. Todas as transações originárias dos bancos são liquidadas através do Sistema de Transferências de Reservas (STR), ou seja, antes de ser efetivada a transação na conta reservas bancárias das instituições as transações devem primeiro ter o aval do STR.
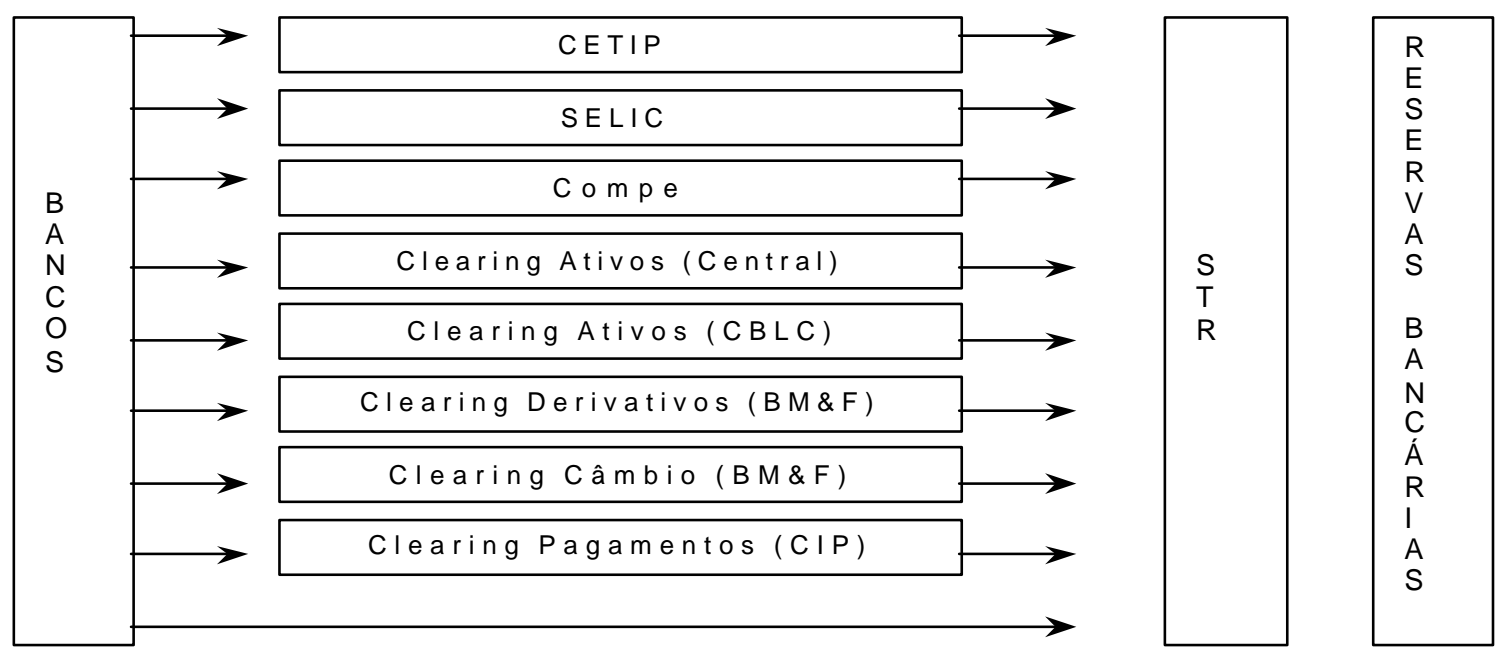

Figura 4 - Liquidação no novo Sistema de Pagamentos Brasileiro.

Fonte: Elaboração do autor 
Os pagamentos ordenados pelos bancos devem contar obrigatoriamente com respaldo de reservas, isto é, eles não podem apresentar saldo negativo, o que implica no cancelamento da operação. Saldos negativos temporários são financiados pelo BACEN a custo zero, por meio do redesconto intradia (no mesmo dia), lastreado em títulos públicos federais. Isso significa que um banco pode utilizar papéis em carteira para comercializá-los junto ao BACEN, com o compromisso de recomprá-los até o final do dia, enquanto negocia os recursos necessários no mercado interbancário.

O Sistema de Pagamentos Brasileiro exige, portanto, monitoramento em tempo real do saldo da conta reservas bancárias de cada banco e a definição de horários a serem observados nos lançamentos dos resultados financeiros provenientes das Clearings.

Para que esse novo SPB funcione deve atuar com base em três formas diferentes de liquidação dos pagamentos interbancários: O Sistema de Transferência de Reservas (STR) para grandes valores, que funciona com base no Real Time Gross Settlement (RTGS - que é o modelo onde a liquidação ocorre pelos valores brutos e em tempo real, operação a operação); as Clearings que funcionam baseadas no Delayed Netting System (DNS - que é o modelo de liquidação no qual as operações ocorrem ao final do dia pelo valor líquido, ou seja, é o netting_resultante da diferença entre as compras e as vendas no decorrer de um certo período de tempo) e existe ainda o modelo de compensação tradicional.

Somente os bancos detentores de contas Reservas Bancárias participam do STR. Para evitar que esse sistema apresente travas decorrentes da interdependência das operações ou situações momentâneas de iliquidez, que não estejam justificadas pela indisponibilidade de recursos de participantes, o BACEN adotou algumas facilidades (de acordo com a tabela 4) para a sua atuação.

De acordo com BIS (2001) a opção pela estruturação de sistemas de grandes valores que liquidam fluxos financeiros dos participantes com base em valores brutos $\mathrm{e}$ em tempo real (RTGS) tem sido a mais utilizada pelos bancos centrais do G10, provavelmente por ser a que mais se adapta aos objetivos de minimização de riscos sistêmicos. Duas importantes fontes de riscos são eliminadas com a adoção de mecanismos do tipo RTGS: não há lapso de tempo entre o envio da ordem de débito ou de crédito e a liquidação financeira propriamente dita (já que as operações se dão em tempo real) e nem nisco de participantes efetivarem as operações sem a devida 
contrapartida financeira (já que esta ocorre, operação a operação, com base nos valores brutos transferidos).

\begin{tabular}{|c|c|}
\hline & $\begin{array}{l}\text { - Podem ser realizadas em favor de contas de liquidação das câmaras de compensação } \\
\text { e de liquidação, do tesouro Nacional, do BACEN e de outras instituições detentoras de } \\
\text { Reservas Bancárias. } \\
\text { - Podem corresponder a pagamento de cliente da instituição debitada em favor de } \\
\text { cliente da instituição favorecida. } \\
\text { - Quando envolverem clientes, serão aceitas ou mantidas em pendência até } \\
\text { determinado horário limite prévio aos demais, quando, se não liquidadas, serão } \\
\text { rejeitadas. }\end{array}$ \\
\hline & $\begin{array}{l}\text { • Somente poderão ser comandados, direta ou indiretamente, pelos detentores das } \\
\text { respectivas contas. } \\
\text { • Serão realizados conforme a ordem cronológica de entrada, enquanto houver saldo } \\
\text { que os suporte. } \\
\text { • Em caso de saldo (ou limite, até 01/01/02) insuficiente, ficarão pendentes, sendo } \\
\text { ordenados segundo os seguintes níveis de prioridade (e, dentro destes, ordem } \\
\text { cronológica): } \\
\text { A = saques de numerário e transferência a crédito de câmara LDL; } \\
\text { B e C = conforme estabelecido pela instituição, nos lançamentos que comandar. } \\
\text { - As operações oriundas do Selic não ficarão pendentes e, em caso de saldo (ou limite, } \\
\text { até 01/01/02) insuficiente, serão rejeitadas e devolvidas ao Selic. } \\
\text { - Lançamentos pendentes no horário limite do STR serão rejeitados pelo sistema. }\end{array}$ \\
\hline $\begin{array}{l}\text { Mecanismo } \\
\text { de } \\
\text { Otimização }\end{array}$ & $\begin{array}{l}\text { - Poderá ser processado pelo BACEN, a seu exclusivo critério, sem horário ou data } \\
\text { preestabelecidos. } \\
\text { - Consiste na simulação do resultado líquido multilateral de todos os lançamentos } \\
\text { pendentes, buscando dar curso ao maior número de lançamentos possível. } \\
\text { - Manterá estrita observância da ordem de pendência dos lançamentos e, caso possam } \\
\text { ser processados, serão efetivados um a um, simultaneamente. }\end{array}$ \\
\hline Câmaras LDL & $\begin{array}{l}\text { - Serão abertas contas de liquidação específicas para câmaras LDL (que utilizam o } \\
\text { conceito de liquidação diferida com base no resultado líquido das operações). } \\
\text { - No caso de câmaras consideradas sistematicamente importantes (segundo critérios a } \\
\text { serem definidos pelo BACEN): a abertura destas contas será obrigatória; a liquidação } \\
\text { financeira de suas operações deverá ser feita diretamente no STR. }\end{array}$ \\
\hline $\mathrm{O}$ & $\begin{array}{l}\text { - Não serão mais admitidos lançamentos com data-valor (realizados em uma data, mas } \\
\text { com efeitos retroativos). }\end{array}$ \\
\hline
\end{tabular}

Quadro 1 - STR: Aspectos Operacionais das Transferências de Reservas.

Fonte: BACEN (2000b) 
A desvantagem desse sistema é que o risco de liquidez ainda existe quando, na liquidação do contrato, o banco remetente não dispuser de fundos; além disso, como os pagamentos são de grandes valores e liquidados pelo valor bruto, a liquidação pelo RTGS exige maior demanda por reservas bancárias, o que, indiretamente, causa a concentração do mercado em poucos bancos (só participando do mercado as maiores instituições).

No projeto do novo SPB as diversas câmaras de compensação estabeleceram um conjunto de regras, definindo os limites de atuação dos bancos em cada um dos ativos. Com isso, espera-se que o mercado exercite com mais intensidade o princípio da auto-regulação, de acordo com a visibilidade sobre as posições e riscos de todas as instituições, passando esses riscos a serem assumidos pelo próprio mercado.

As câmaras de compensação utilizam-se do RTGS e as câmaras de liquidação são autorizadas a processar operações através do conceito de DNS.

De acordo com BIS (2002b), no sistema DNS a liquidação das operações ocorre ao final do período com a transferência do valor líquido multilateral das operações. Esse sistema é mais adequado para se administrar os riscos das operações de câmbio e entre as suas principais vantagens tem-se a exigência de uma baixa demanda por reservas bancárias (a compensação multilateral dos valores entre os participantes reduz o volume de recursos a serem transferidos, beneficiando os bancos que reduzem os custos de oportunidade de se manter encaixes ociosos) e a eliminação do risco de principal através da utilização do princípio de pagamento versus pagamento (PVP). Em termos operacionais ocorre a simplificação de forma substancial do processo de liquidação pois se trabalha com valores líquidos compensados, evitando a movimentação de valores brutos operação por operação. A desvantagem desse sistema se refere à defasagem de tempo na liquidação, a qual cria uma concessão "implícita" de crédito do banco recebedor para o banco comprador, expondo os participantes ao risco de crédito. Essas vantagens e desvantagens do RTGS e do DNS são melhor visualizadas na tabela 5 .

Um exemplo ajuda a entender a diferença entre os sistemas RTGS e DNS. Suponha um banco que compre US $\$ 100$ milhões em 10 operações de US $\$ 10$ milhões e venda US $\$ 90$ milhões em 9 operações de US $\$ 10$ milhões. Pelo sistema RTGS esse banco receberá 10 créditos de US $\$ 10$ milhões e emitirá 9 ordens de pagamento também de US\$10 milhões, sendo cada uma com os respectivos pagamentos e 
recebimentos em moeda nacional. Se essa transação ocorresse pelo sistema DNS, o banco vendedor teria emitido uma única ordem de pagamento de US\$10 milhões, correspondendo ao saldo líquido compensado.

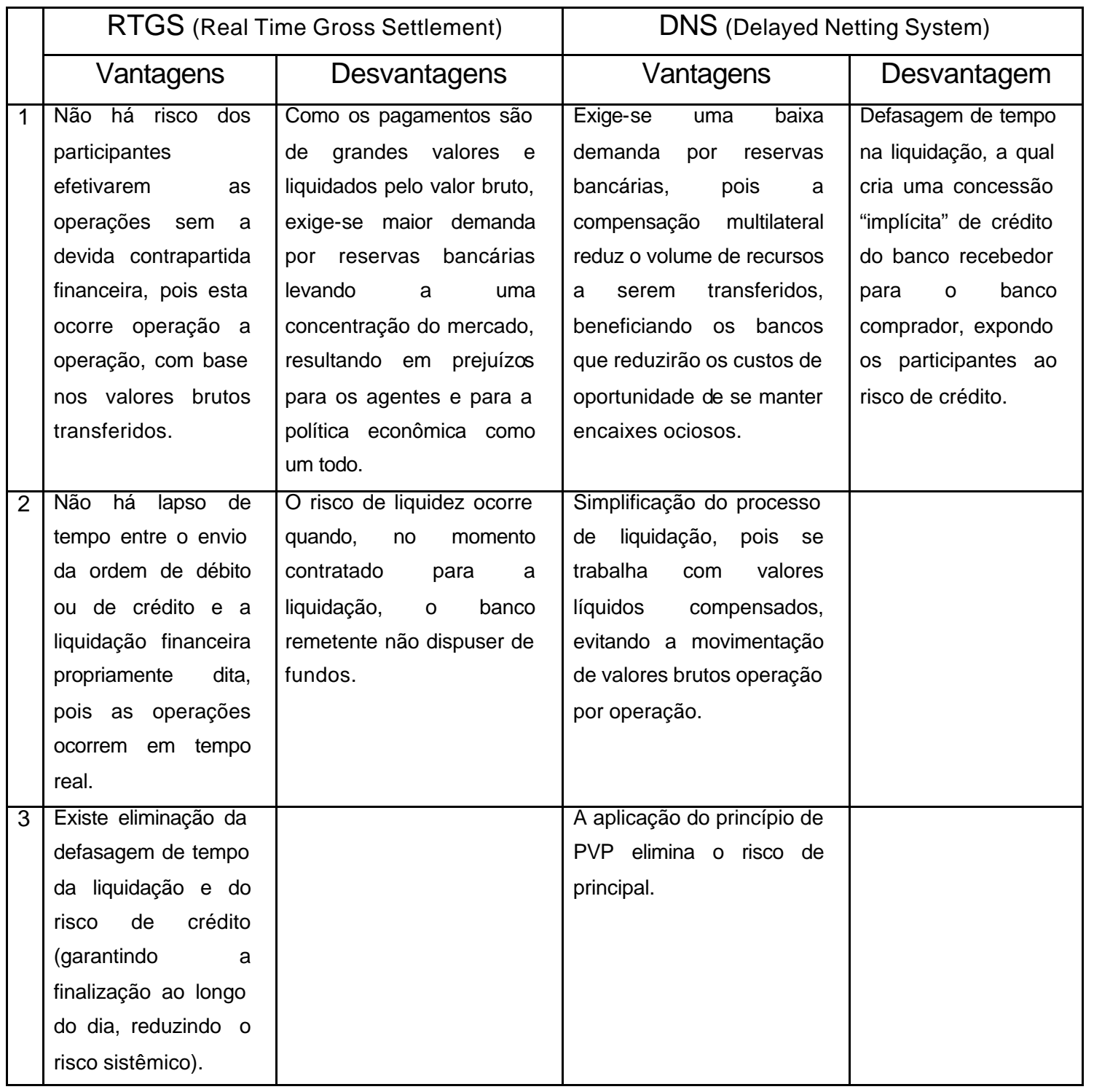

Quadro 2 - Diferenças entre os sistemas de liquidação interbancárias.

Fonte: Elaboração do autor

Para fazer a transferência de valores em tempo real foi criada a TED (Transferência Eletrônica Disponível). Esse mecanismo de liquidação financeira é semelhante ao DOC, diferenciando deste apenas na velocidade com que a 
transferência se efetiva. Quando um DOC é emitido, o dinheiro sai da conta na mesma hora, mas ele só vai ficar disponível na conta do recebedor em $\mathrm{D}+1$, ou seja, no dia seguinte. A liquidação via TED ocorre no mesmo dia da transferência, ou seja, o valor creditado na conta do favorecido está disponível para uso assim que o banco do favorecido recebe a mensagem de transferência. Desse modo, o favorecido passa a ter acesso àinformação do crédito no mesmo instante do recebimento.

$O$ limite para as transações via TED é de $R \$ 5$ mil. Esse valor surgiu de simulações realizadas pelo BACEN, que demonstraram que as operações financeiras liquidadas por meio de cheques e de DOC acima desse valor trazem um grande risco de gerar prejuízos para a sociedade, como conseqüência de um eventual problema financeiro de um banco qualquer. Ao se reduzir os cheques e DOC de valor igual ou superior a $\mathrm{R} \$ 5$ mil, o risco sistêmico consequentemente se reduz.

Verifica-se no quadro 3 que a quantidade de cheques acima de $\mathrm{R} \$ 5$ mil é pouco mais de $1 \%$ do total, mas equivalente a um montante de $70 \%$ do total transacionado. Já a quantidade de DOC acima de $\mathrm{R} \$ 5$ mil representa menos de $15 \%$ do total, mas equivalente a $97 \%$ do montante total.

\begin{tabular}{|c|c|c|c|c|c|c|}
\hline \multirow{2}{*}{} & \multicolumn{2}{|c|}{ Até $\mathrm{R} \$ 5$ mil } & \multicolumn{2}{c|}{ Mais de $\mathrm{R} \$ 5$ mil } & \multicolumn{2}{c|}{ TOTAL } \\
\cline { 2 - 7 } & Quantidade & $\%$ & Quantidade & $\%$ & Quantidade & $\%$ \\
\hline Cheques & 9.704 .000 & 98,7 & 124.000 & 1,3 & 9.828 .000 & 100 \\
DOC & 287.200 & 85,2 & 49.900 & 14,8 & 337.100 & 100 \\
\cline { 2 - 7 } & Montante & $\%$ & Montante & $\%$ & Montante & $\%$ \\
\hline Cheques & $\mathrm{R} \$ 1,8$ bilhão & 30 & $\mathrm{R} \$ 4,2$ bilhões & 70 & $\mathrm{R} \$ 6,0$ bilhões & 100 \\
DOC & $\mathrm{R} \$ 0,2$ bilhão & 3 & $\mathrm{R} \$ 6,0$ bilhões & 97 & $\mathrm{R} \$ 6,2$ bilhões & 100 \\
\hline
\end{tabular}

Quadro 3 - Média de cheques e DOC entre fevereiro e agosto de 2001.

Fonte: BACEN (2001b)

Assim, ao estabelecer um mecanismo que evite a emissão de cheques e DOC acima de $\mathrm{R} \$ 5$ mil, reduz-se o risco sistêmico. $O$ risco médio total entre fevereiro e agosto de 2001 (representado pelo volume transacionado nesse período), na compensação de cheques e DOC, é de $\mathrm{R} \$ 12,2$ bilhões e o montante desse risco a partir de $R \$ 5$ mil é de $R \$ 10,2$ bilhões, ou seja $85 \%$ do total. Assim, ao impor o limite no valor das transações, o risco de compensação se reduz a cerca de $15 \%$ do montante total transacionado, eqüivalente a cerca de $R \$ 2$ bilhões. 
É interessante destacar algumas mudanças e os novos produtos que surgiram juntamente com o novo SPB. A principal foi a Implantação do Sistema de Transferências de grandes valores em tempo real (no qual os pagamentos são acelerados). Também merece destaque o surgimento de Câmaras de Compensação privadas (assumindo o setor privado o seu próprio risco), a introdução do Depósito Prévio da Compe (esse mecanismo gera a redução do volume financeiro diário da Câmara de Compensação), a reestruturação da infra-estrutura tecnológica e dos sistemas de processamento de dados (com isso, atendendo os requisitos de ajuste ao novo SPB) e por fim a redução no volume de cheques repassados pelos bancos (aumentando a importância de produtos como os cartões de débito e de crédito).

Essas modificações ocorrem de maneira distinta de acordo com o setor analisado. As novidades para as pessoas físicas estão mostradas na tabela 7 .

\begin{tabular}{|c|l|}
\hline \multicolumn{2}{|c|}{ PESSOA FISICA } \\
\hline 1 & $\begin{array}{l}\text { Utilização do STR (em tempo real de forma definitiva e segura, via TED) ou a CIP (com garantia de liquidação) } \\
\text { como opção para pagamentos e transferências de recursos, além dos tradicionais cheques, DOCs e cartões em } \\
\text { geral. }\end{array}$ \\
\hline 2 & Necessidade de saldo disponível sempre que forem utilizados o STR e a CIP \\
\hline 3 & Crédito instantâneo de qualquer soma enviada ou transferida eletronicamente pelo novo sistema (STR ou CIP) \\
\hline 4 & Desestímulo àemissão de cheques ou DOCs com valores a partir de R\$5 mil \\
\hline 5 & $\begin{array}{l}\text { As aplicações financeiras (exceto poupança) só são efetivadas mediante a existência de saldo disponível em } \\
\text { conta }\end{array}$ \\
\hline 6 & $\begin{array}{l}\text { Foi alterada a sistemática de emissão e resgate de quotas de fundos e investimentos. Para rendimento no } \\
\text { mesmo dia, os Fundos de Investimento devem emitir uma TED, caso contrário só passarão a render no dia } \\
\text { seguinte. }\end{array}$ \\
\hline 7 & Estímulo ao agendamento de operações (TED programada); \\
\hline 8 & $\begin{array}{l}\text { Intensificação do uso de canais alternativos (Internet Banking e Centrais Telefônicas dos bancos) para a } \\
\text { realização de transferências; }\end{array}$ \\
\hline 9 & $\begin{array}{l}\text { Os bancos podem negociar taxas diferenciadas para a realização de aplicações em função da condição do saldo } \\
\text { verificado na conta corrente no momento da transação - disponível ou bloqueado; }\end{array}$ \\
\hline 10 & \begin{tabular}{l} 
Tarifas diferenciadas de acordo com o meio pelo qual são realizadas as transferências (Compe, CIP ou STR). \\
\hline
\end{tabular}
\end{tabular}

Quadro 4 - Mudanças para as pessoas físicas com o novo SPB.

Fonte: Federação Brasileira dos Bancos - FEBRABAN (2002)

Para a grande maioria das operações feitas no dia-a-dia, o novo sistema não foi percebido, pois são inferiores a $R \$ 5$ mil. As mudanças são melhor observadas quando 
ocorrem transferências a partir deste valor. Além disso, a necessidade de saldo disponível demanda um controle maior do correntista sobre as entradas e saídas de recursos, uma vez que não é mais permitida a emissão de ordens de pagamento em tempo real sobre valores ainda não disponíveis.

Vale ressaltar os custos da emissão de uma Transferência Eletrônica Disponível (TED). Esses custos são bem menores que aqueles para os Documentos de Crédito (DOCs), como pode ser visto pela tabela 8. A migração para esse novo sistema de transferência tende a aumentar àmedida em que se popularizar e ganhar a confiança do mercado.

Várias mudanças também ocorreram para as pessoas jurídicas. As empresas são afetadas de forma mais direta com as mudanças do novo SPB, pois sua tesouraria movimenta diariamente volumes financeiros maiores que os de um correntista comum. O grande problema para os tesoureiros das empresas é ater-se ao risco de descasamento de fluxos financeiros, principalmente na hora de acertar prazos de pagamentos ou de recebimentos e a modalidade de realização da transferência.

A implantação do novo SPB não só afeta os procedimentos tradicionais de processamento de transações financeiras, mas principalmente representa uma nova cultura que deve ser disseminada na sociedade, uma vez que produz mudanças em práticas comerciais consagradas pelo mercado, como o uso do cheque como instrumento de crédito. As tarifas das TED para as pessoas jurídicas também são bem menores do que aquelas cobradas para a realização de DOC. Essas tarifas e as principais mudanças para as empresas estão representadas nas tabelas 9 e 10 , respectivamente.

As empresas comerciais também procuram incentivar a utilização dos cartões de crédito e de débito. Segundo Rabello (in Nunes, 2002) a estimativa de crescimento do uso desses cartões é de $53 \%$ em 2002, alcançando um faturamento de $R \$ 10$ bilhões. A utilização desses cartões tende a agilizar o pagamento das compras realizadas pelas pessoas, reduzindo a inadimplência e o atraso nos pagamentos. 
Tabela 4. Valores das tarifas bancárias cobradas por vários bancos para as operações de DOC e TED realizadas pelas pessoas físicas.

\begin{tabular}{|c|c|c|c|c|c|}
\hline \multicolumn{2}{|r|}{ INSTITUIÇÃO FINANCEIRA } & \multicolumn{2}{|c|}{ DOC } & \multicolumn{2}{|c|}{ TED } \\
\hline & & "C" & “D” & Na agência & Term. Eletrôn. \\
\hline 1 & Banco Triângulo S. A. & 30,00 & 30,00 & 10,00 & 2,00 \\
\hline 2 & Banco do Estado de Sergipe S.A. & 30,00 & 30,00 & 5,00 & 1,00 \\
\hline 3 & Banco Industrial do Brasil S. A. & 20,00 & 15,01 & 10,00 & 3,00 \\
\hline 4 & Banco do Est. do Maranhão S.A. & 15,00 & 15,00 & 5,00 & 1,00 \\
\hline 5 & Banco do Brasil S.A. & 15,00 & 15,00 & $n / d$ & 1,00 \\
\hline 6 & Banco Cacique S.A. & 13,00 & 13,00 & 13,00 & 3,00 \\
\hline 7 & Banco de Pernambuco S.A. & 13,00 & 13,00 & 11,00 & 1,80 \\
\hline 8 & Banco Rural S.A. & 12,00 & 12,00 & 12,00 & 1,00 \\
\hline 9 & Banco Citibank S.A. & 12,00 & 12,00 & 10,00 & 1,20 \\
\hline 10 & Banco Paulista S.A. & 12,00 & 10,00 & 9,00 & 1,50 \\
\hline 11 & Banco Cooperativo do Brasil S.A. & 12,00 & 8,50 & 5,00 & 1,00 \\
\hline 12 & Banco ABN AMRO Real S.A. & 11,00 & 11,00 & 11,00 & 1,50 \\
\hline 13 & Banco Bilbao Vizcaya Arg. Brasil S.A. & 11,00 & 11,00 & 9,90 & 1,00 \\
\hline 14 & Banco BCN S.A. & 10,80 & 10,80 & 10,80 & 1,20 \\
\hline 15 & HSBC Bank Brasil S.A. - Banco Múltiplo & 10,80 & 10,80 & $n / d$ & 1,30 \\
\hline 16 & Banco Mercantil de São Paulo S.A. & 10,60 & 10,60 & 10,60 & 1,00 \\
\hline 17 & Banco Santander Brasil S.A. & 10,50 & 9,50 & $n / d$ & 2,74 \\
\hline 18 & Banco Santos S.A. & 10,00 & 15,00 & 10,00 & 1,00 \\
\hline 19 & Banco Inter American Express S.A. & 10,00 & 10,00 & 10,00 & 2,00 \\
\hline 20 & Banco Industrial e Comercial S.A. & 10,00 & 10,00 & 10,00 & 1,35 \\
\hline 21 & BankBoston, N.A. & 10,00 & 10,00 & 10,00 & 1,00 \\
\hline 22 & BankBoston Banco Múltiplo S.A. & 10,00 & 10,00 & 10,00 & 1,00 \\
\hline 23 & Banco Sudameris Brasil S.A. & 10,00 & 10,00 & 10,00 & 1,00 \\
\hline 24 & Banco do Nordeste do Brasil S.A. & 10,00 & 10,00 & 8,00 & 1,50 \\
\hline 25 & Banco do Estado do Pará S.A. & 10,00 & 10,00 & 7,00 & 1,50 \\
\hline 26 & Unibanco - União de Bcos Brasileiros S.A. & 10,00 & 10,00 & $n / d$ & 1,50 \\
\hline 27 & Banco BonSucesso S.A. & 10,00 & 10,00 & $n / d$ & 1,50 \\
\hline 28 & Banco Com. E de Inv. Sudameris S.A. & 10,00 & 10,00 & $n / d$ & 1,00 \\
\hline 29 & Banco Itaú S.A. & 10,00 & 10,00 & $n / d$ & 0,90 \\
\hline 30 & Banco Bradesco S.A. & 9,80 & 9,80 & 9,80 & 1,30 \\
\hline 31 & Banco Mercantil do Brasil S.A. & 9,00 & 10,00 & $n / d$ & 1,50 \\
\hline 32 & Banestes S.A. & 9,00 & 9,00 & 9,00 & 1,50 \\
\hline 33 & Banco do Estado de São Paulo - Banespa & 9,00 & 9,00 & $n / d$ & 1,30 \\
\hline 34 & Banco Banestado S.A. & 8,90 & 8,90 & $n / d$ & 2,20 \\
\hline 35 & Banco do Est. do Rio Grande do Sul S.A. & 8,50 & 8,50 & 6,50 & 1,50 \\
\hline 36 & Banco do Est. do Piauí - BEP & 8,50 & 5,00 & $n / d$ & 1,00 \\
\hline 37 & Banco de Brasília S.A. - BRB & 8,00 & 8,00 & 8,00 & 5,00 \\
\hline 38 & Banco do Est. de Santa Catarina S.A. & 6,00 & 6,00 & 10,00 & 1,20 \\
\hline 39 & Banco Cooper. SICREDI S.A. & 6,00 & 6,00 & 6,00 & 0,70 \\
\hline 40 & Banco Lloyds TSB S.A. & 5,00 & 5,00 & $n / d$ & 3,00 \\
\hline
\end{tabular}

Fonte: BACEN (2002b)

Nota: Valores em $\mathrm{R} \$ /$ evento do dia 13/08/2002. 
Tabela 5. Valores das tarifas bancárias cobradas por vários bancos para as operações de DOC e TED realizadas pelas pessoas jurídicas.

\begin{tabular}{|c|c|c|c|c|c|}
\hline \multicolumn{2}{|r|}{ INSTITUIÇÃO FINANCEIRA } & \multicolumn{2}{|c|}{ DOC } & \multicolumn{2}{|c|}{ TED } \\
\hline & & "C" & “D” & $\mathrm{Na}$ agência & Term. Eletrôn. \\
\hline 1 & Banco BCN S.A. & 50,00 & 50,00 & 50,00 & 4,20 \\
\hline 2 & Banco Triângulo S. A. & 30,00 & 30,00 & 10,00 & 2,00 \\
\hline 3 & Banco do Estado de Sergipe S.A. & 30,00 & 30,00 & 5,00 & 1,00 \\
\hline 4 & Banco Industrial do Brasil S. A. & 20,00 & 15,01 & 10,00 & 3,00 \\
\hline 5 & Banco do Est. do Maranhão S.A. & 15,00 & 15,00 & 5,00 & 1,00 \\
\hline 6 & Banco do Brasil S.A. & 15,00 & 15,00 & $n / d$ & 1,50 \\
\hline 7 & Banco Cacique S.A. & 13,00 & 13,00 & 13,00 & 3,00 \\
\hline 8 & Banco de Pernambuco S.A. & 13,00 & 13,00 & 11,00 & 1,80 \\
\hline 9 & Banco Rural S.A. & 12,00 & 12,00 & 12,00 & 1,00 \\
\hline 10 & Banco Citibank S.A. & 12,00 & 12,00 & 10,00 & 1,20 \\
\hline 11 & Banco Paulista S.A. & 12,00 & 10,00 & 9,00 & 1,50 \\
\hline 12 & Banco Cooperativo do Brasil S.A. & 12,00 & 8,50 & 5,00 & 1,00 \\
\hline 13 & Banco ABN AMRO Real S.A. & 11,00 & 11,00 & 11,00 & 1,50 \\
\hline 14 & Banco Bilbao Vizcaya Arg. Brasil S.A. & 11,00 & 11,00 & 9,90 & 1,00 \\
\hline 15 & HSBC Bank Brasil S.A. - Banco Múltiplo & 10,80 & 10,80 & $n / d$ & 1,20 \\
\hline 16 & Banco Mercantil de São Paulo S.A. & 10,60 & 10,60 & 10,60 & $n / d$ \\
\hline 17 & Banco Santander Brasil S.A. & 10,50 & 9,50 & $n / d$ & 2,74 \\
\hline 18 & Banco Santos S.A. & 10,00 & 15,00 & 10,00 & 1,00 \\
\hline 19 & Banco Inter American Express S.A. & 10,00 & 10,00 & 10,00 & 2,00 \\
\hline 20 & Banco Industrial e Comercial S.A. & 10,00 & 10,00 & 10,00 & 1,35 \\
\hline 21 & BankBoston, N.A. & 10,00 & 10,00 & 10,00 & 1,00 \\
\hline 22 & BankBoston Banco Múltiplo S.A. & 10,00 & 10,00 & 10,00 & 1,00 \\
\hline 23 & Banco Sudameris Brasil S.A. & 10,00 & 10,00 & 10,00 & 1,00 \\
\hline 24 & Banco do Nordeste do Brasil S.A. & 10,00 & 10,00 & 8,00 & 2,00 \\
\hline 25 & Banco do Estado do Pará S.A. & 10,00 & 10,00 & 7,00 & 1,50 \\
\hline 26 & Unibanco - União de Bcos Brasileiros S.A. & 10,00 & 10,00 & $n / d$ & 1,50 \\
\hline 27 & Banco BonSucesso S.A. & 10,00 & 10,00 & $n / d$ & 1,50 \\
\hline 28 & Banco Com. e de Inv. Sudameris S.A. & 10,00 & 10,00 & $n / d$ & 1,00 \\
\hline 29 & Banco Itaú S.A. & 10,00 & 10,00 & $n / d$ & 0,90 \\
\hline 30 & Banco Bradesco S.A. & 9,80 & 9,80 & 9,80 & 1,30 \\
\hline 31 & Banco Mercantil do Brasil S.A. & 9,00 & 10,00 & $n / d$ & 1,50 \\
\hline 32 & Banestes S.A. & 9,00 & 9,00 & 9,00 & 1,50 \\
\hline 33 & Banco do Estado de São Paulo - Banespa & 9,00 & 9,00 & $n / d$ & 1,30 \\
\hline 34 & Banco Banestado S.A. & 8,90 & 8,90 & $n / d$ & 2,20 \\
\hline 35 & Banco do Est. do Rio Grande do Sul S.A. & 8,50 & 8,50 & 6,50 & 1,50 \\
\hline 36 & Banco do Est. do Piauí - BEP & 8,50 & 5,00 & $n / d$ & 1,00 \\
\hline 37 & Banco de Brasília S.A. - BRB & 8,00 & 8,00 & 8,00 & 5,00 \\
\hline 38 & Banco do Est. de Santa Catarina S.A. & 6,00 & 6,00 & 10,00 & 1,20 \\
\hline 39 & Banco Cooper. SICREDI S.A. & 6,00 & 6,00 & 6,00 & 0,70 \\
\hline 40 & Banco Lloyds TSB S.A. & 5,00 & 5,00 & $n / d$ & 3,00 \\
\hline
\end{tabular}

Fonte: BACEN (2002b)

Nota: Valores em $\mathrm{R} \$ /$ evento do dia 13/08/2002. 
Tabela 6. Mudanças para as pessoas jurídicas com o novo SPB.

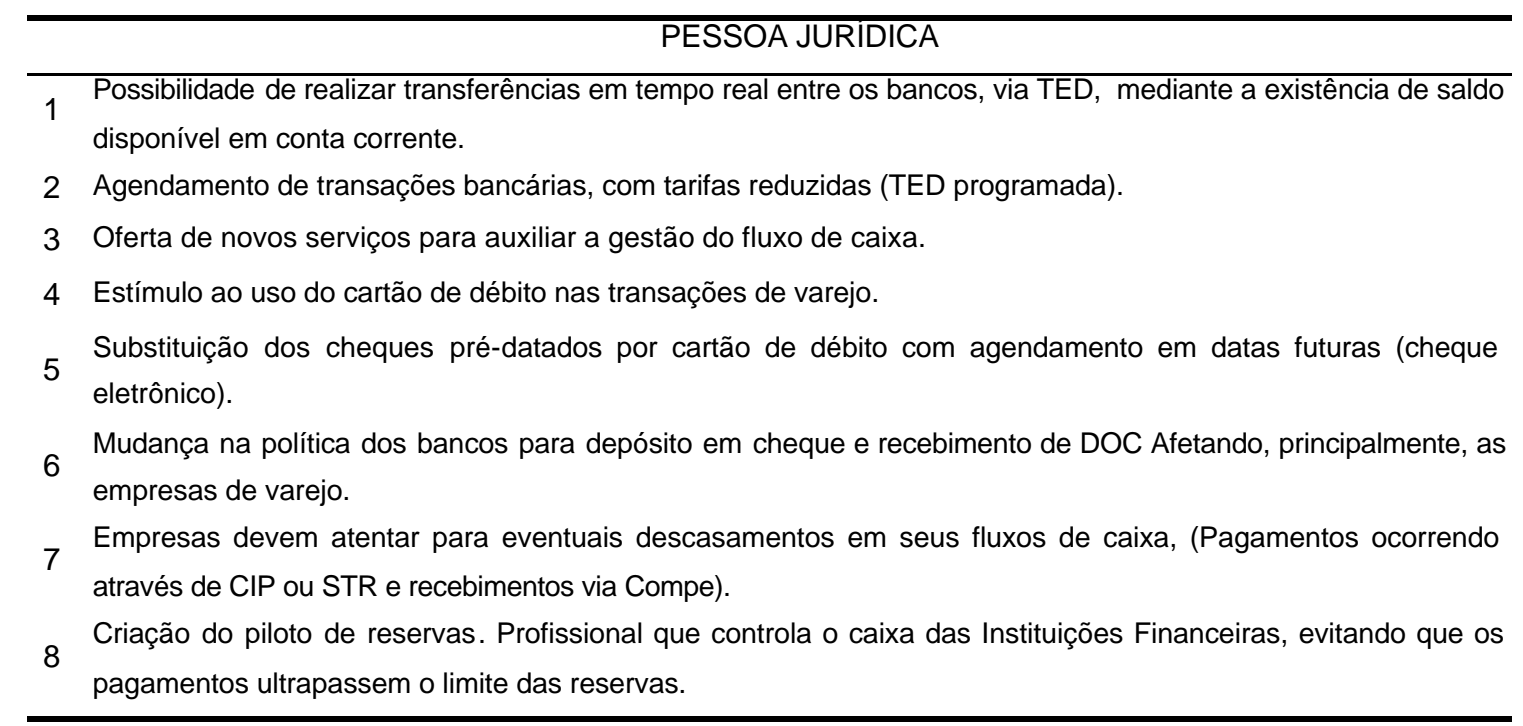

Fonte: FEBRABAN (2002)

O terceiro setor a sofrer modificações com o novo SPB é a Administração Pública. Os gestores das finanças públicas tanto estaduais, quanto municipais, também são afetados pois administram um fluxo de caixa que movimenta diariamente transações de valores a partir de $R \$ 5$ mil.

Algumas transações financeiras entretanto não se modificaram. Como por exemplo os pagamentos de contas diversas e de concessionárias de serviços públicos (agências bancárias, casas lotéricas e terminais eletrônicos), transações através do uso de cartões de crédito e débito, emissão de cheques e DOC abaixo de $\mathrm{R} \$ 5$ mil, prazos de bloqueio e compensação para cheques e depósitos em cheques até $\mathrm{R} \$ 5$ mil em poupança. Também não houve alteração para os produtos de Capitalização, Seguros e Previdência Privada.

Todas as instituições financeiras (incluindo os bancos) sofreram alterações no seu grau de alavancagem. De acordo com Carvalho et al (2000), por grau de alavancagem entende-se a relação entre o volume de depósitos e de reservas que cada instituição possui. Esse conceito é compatível com a análise dos riscos de intermediação financeira, isto é, com o estado de expectativa dos bancos, refletido pela sua preferência pela liquidez. Assim, quanto mais alavancada uma instituição trabalha, mais riscos ela assume. 
Os bancos são vulneráveis a resgates acentuados dos seus depósitos, dependendo da relação reservas/depósitos. Dado o estoque de reservas dos bancos comerciais, a criação de depósitos representa uma redução da relação reservas e ativos de alta liquidez sobre os depósitos à vista. Reduzindo os depósitos à vista aumenta-se a vulnerabilidade financeira dos bancos. Essa vulnerabilidade é tanto maior quanto menor for o tamanho e a profundidade dos mercados interbancários.

Carvalho et al (2000) também mostram que dada a estrutura dos mercados financeiros e o acesso dos bancos a fontes de liquidez, a vulnerabilidade aceita pelos bancos associa-se diretamente à percepção dos riscos adicionais (de default, de liquidez e de juros) na medida em que se ampliam os depósitos.

Ao ampliar a percepção dos riscos totais, os bancos tendem a se tornar mais conservadores para um dado estado de expectativas, tornando-se mais seletivos em relação aos créditos, buscando aumentar os requisitos em termos de garantias e o spread de juros em suas operações. Assim, uma demanda crescente de crédito para um dado estado de expectativas dos bancos tende a ser racionada ao longo do processo de crescimento. Para uma economia em crescimento, como a brasileira, em que o financiamento se baseia em crédito bancário, o racionamento de crédito se dá não apenas porque há uma assimetria de informações, mas também por outros motivos, entre eles o nível de alavancagem bancária, na medida em que este nível alcança limites máximos aceitos pelos bancos (dadas as suas expectativas) acomodando as demandas crescentes por crédito.

Assim, no contexto de crescimento, o racionamento de crédito mais relevante se deve a uma seleção mais criteriosa dos crescentes riscos percebidos de crédito de empréstimos. 


\section{MERCADO DE CÂMBIO}

\subsection{Funcionamento}

As transações interbancárias entre moedas estrangeiras envolvem três tipos de agentes: o comercial, o financeiro e o BACEN. Esses três agentes se relacionam com o setor interbancário, realizando com este transações responsáveis pelo aumento ou pela redução de moedas estrangeiras no país.

Por agente comercial entende-se aquele responsável diretamente pela comercialização de bens e serviços no país, tais como as indústrias, as lojas comerciais, a agricultura, entre outros. Por agente financeiro entende-se aquele responsável pelo investimento no país, tais como os bancos e as empresas multinacionais. A esses dois agentes chamamos "agentes primários" (Garófalo Filho, 2000). O BACEN é o responsável pela política cambial, interferindo no mercado de câmbio comprando e vendendo moeda estrangeira visando manter em equilíbrio o setor interbancário.

Através da exportação e da importação de bens e serviços, o agente comercial interfere no mercado de câmbio. Quando há uma exportação de bens e serviços por parte dos produtores brasileiros ocorre uma importação em algum outro país. Desse modo, existe uma transferência de moeda estrangeira para o setor bancário e ao mesmo tempo transferência de reais para o exportador. Quando há uma importação de bens e serviços por parte do agente comercial brasileiro existe uma transferência de reais para o setor interbancário e a transferência de moeda estrangeira para o importador.

O agente financeiro interfere no setor bancário através do envio e recebimento de investimentos. Para ingressar no Brasil, o investidor estrangeiro transfere sua moeda ao setor bancário e este transfere reais para o Brasil. Já quando o agente 
financeiro remete moeda para o exterior, tem-se o seguinte processo: o investidor brasileiro transfere reais para o setor interbancário e este transfere moeda estrangeira para o Brasil.

O BACEN procura intervir no setor interbancário sempre que este se encontra em desequilíbrio, realizando políticas cambiais que o leve ànormalidade. Uma situação possível para essas intervenções é o setor interbancário estar saturado de moeda estrangeira e com poucos reais em caixa. Nesse caso, para que o equilíbrio se processe, o BACEN compra moeda estrangeira, reduzindo o montante dessa moeda em excesso e transferindo reais para o mercado. Uma última situação possível é a existência de um desequilíbrio no setor interbancário, dado pelo excesso de reais neste setor. Nessa situação o BACEN novamente intervêm buscando equilibrar este setor. Esta intervenção ocorre através da venda de moeda estrangeira, com isso reais são transferidos do setor interbancário para o BACEN e moeda estrangeira se transfere para o setor interbancário.

Essas são as formas como os agentes se relacionam com o setor interbancário e estão ilustradas na figura 5 .

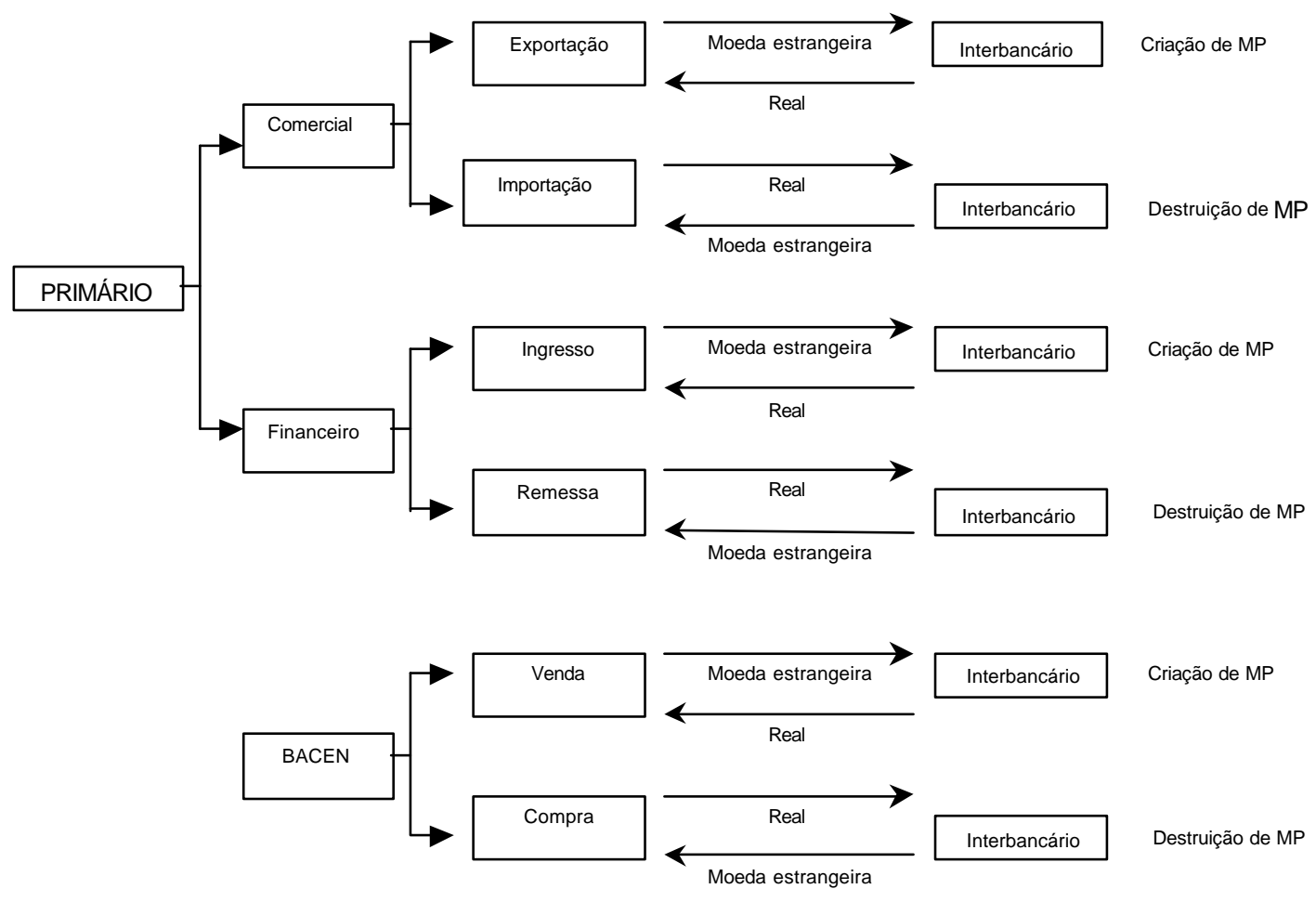

Figura 5 - Mercado de Câmbio Brasileiro.

Fonte: Elaboração do autor 
Nessas relações ocorre criação e destruição de moeda nacional, afetando os meios de pagamentos (MP). Tem-se criação de MP quando aumenta o volume de reais em poder da público não-bancário e destruição quando esse volume diminui.

\subsubsection{Aspectos operacionais dos contratos de câmbio}

A antiga estrutura de operações de câmbio vigente no mercado cambial brasileiro podia ser dividida em três etapas: contratação, registro e liquidação, que estão descritas a seguir.

Contratação da Operação: Ocorria em D+0 e nela os operadores, geralmente por contato telefônico, convencionavam entre si as condições das operações, como por exemplo: taxa de câmbio, montante, data para liquidação, forma de pagamento da moeda estrangeira, etc.

Registro da Operação: Ocorria em D+0 e nesse caso, os registros das operações eram feitos nos computadores do BACEN no mesmo dia da contratação. Esses registros tinham força de contrato de câmbio entre as partes, conforme legislação em vigor. A Contratação e o Registro das operações estão mostradas na figura 6. Nela verifica-se que o BACEN é o responsável pela confirmação das operações

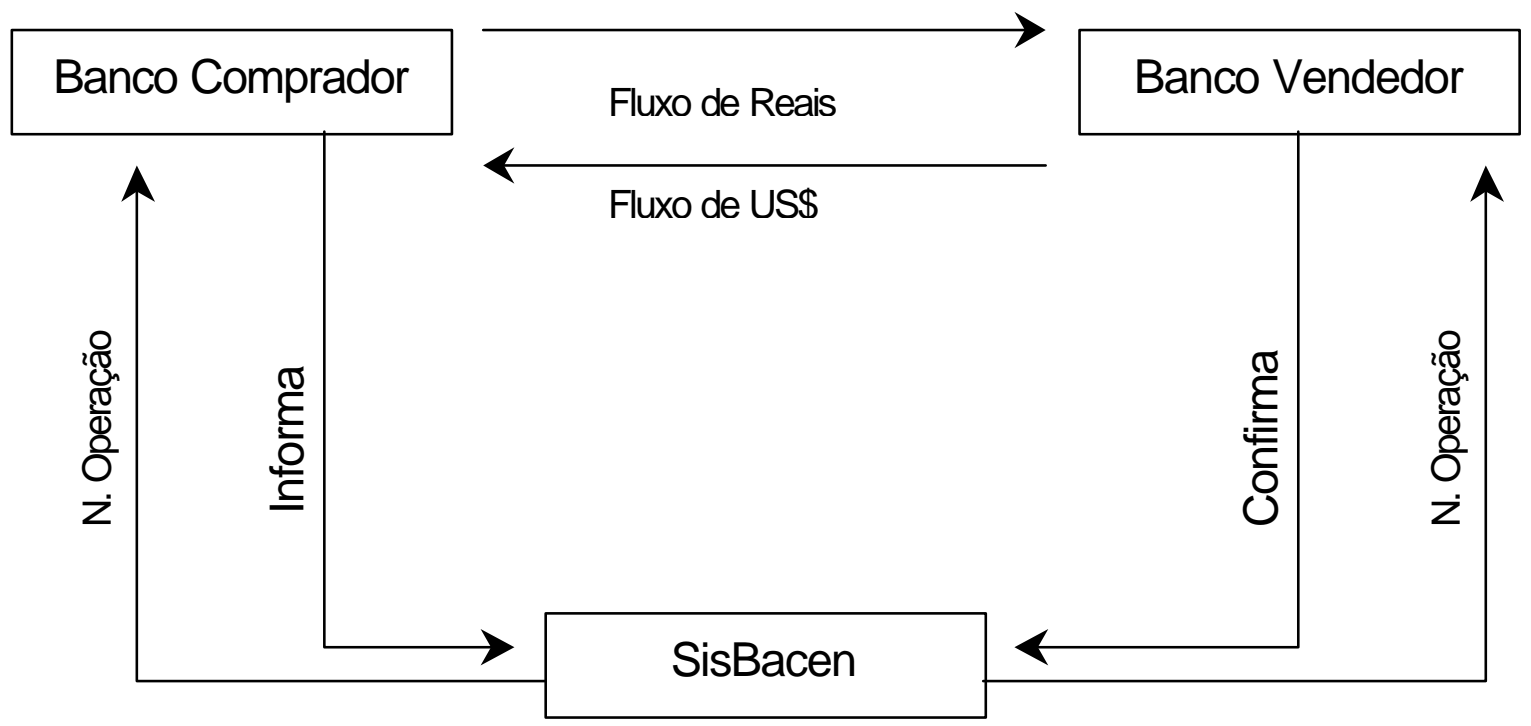

Figura 6 - Contratação e Registro no Sisbacen.

Fonte: Garófalo Filho (2000) 
Liquidação da Operação: Ocorria em D+N (essa data era acertada no ato da contratação da operação), sendo a liquidação da moeda nacional feita automaticamente por débitos e créditos na "Conta Reservas Bancárias" dos participantes compradores e vendedores com o BACEN, independente da existência de saldo. Quando havia saldo disponível por parte do banco comprador, o sistema fluía normalmente, mas quando esse saldo não existia ocorria um saque a descoberto e surgia o risco do BACEN.

O BACEN assumia esse risco por duas razões: uma de ordem operacional, pois naquele modelo de funcionamento da "Conta Reservas Bancárias", somente no dia seguinte ao lançamento era possível fazer a verificação da existência ou não de saldo necessário; a outra, de ordem sistêmica, pois o sistema de pagamentos brasileiro não dispunha de mecanismos para conter a propagação desse risco.

Caso o BACEN se recusasse a realizar um débito, podia acontecer de um participante do mercado perder a moeda nacional e a estrangeira ao mesmo tempo, além de colocá-lo em situação de inadimplência em outros mercados (como Selic, Cetip, Bolsas, etc.) ou até mesmo com clientes no mercado primário (como exportadores, importadores e investidores).

Já a liquidação da moeda estrangeira estava fora do âmbito do BACEN pois era realizada, operação por operação, junto aos bancos correspondentes dos operadores no exterior?.

Antigamente um operador que comprasse US $\$ 10$ milhões em dez operações de US\$ 1 milhão e vendesse os mesmos US\$10 milhões em dez operações de US\$ 1 milhão era obrigado a emitir dez ordens de pagamento para liquidar suas vendas, recebendo também em dez parcelas, independente de ter comprado de um único banco ou de bancos diferentes. Em muitas situações o operador era obrigado a recorrer a linhas de crédito no exterior para pagar o mesmo valor que iria receber, em função da não-simultaneidade dos pagamentos.

Detalhadamente a operação ocorria da seguinte forma: se o banco vendedor, ao emitir a ordem de pagamento, possuísse saldo no banco estrangeiro

\footnotetext{
${ }^{9}$ Em geral, os pagamentos da moeda estrangeira eram feitos por intermédio de Clearings, como CHIPS (Clearing House Interbank Payment System), em Nova lorque; de sistema de transferência de grandes valores em tempo real, como FEDWIRE, do centralizador norte-americano, Federal Reserve Bank; ou de lançamentos internos ou booktransfers, quando se trata de correspondente no exterior comum a dois ou mais bancos brasileiros.
} 
correspondente, haveria a emissão de um aviso de crédito por parte do banco estrangeiro para o banco comprador. Se não existisse saldo no banco estrangeiro, este devolveria a ordem de pagamento para o banco vendedor, surgindo o risco para o banco comprador.

Assim, um banco pode vender câmbio para honrar um compromisso com operações de Selic, Cetip ou Bolsas, ou comprar câmbio para liquidar um contrato de importação ou de remessa para um investidor. Caso ocorra inadimplência no mercado de câmbio, pode se iniciar uma reação em cadeia dentro do mercado financeiro. Nesse caso surge a necessidade de criação de uma instituição de mecanismos que gerencie os riscos desse mercado. Cria-se então uma Clearing e adota-se o princípio de pagamento contra pagamento (recomendado internacionalmente para as operações de espécie). Para as instituições essa consequência é muito benéfica, pois reduz o custo de oportunidade de se manter reservas ociosas.

Toda a operação de liquidação da moeda nacional e estrangeira está representada na figura 7 .

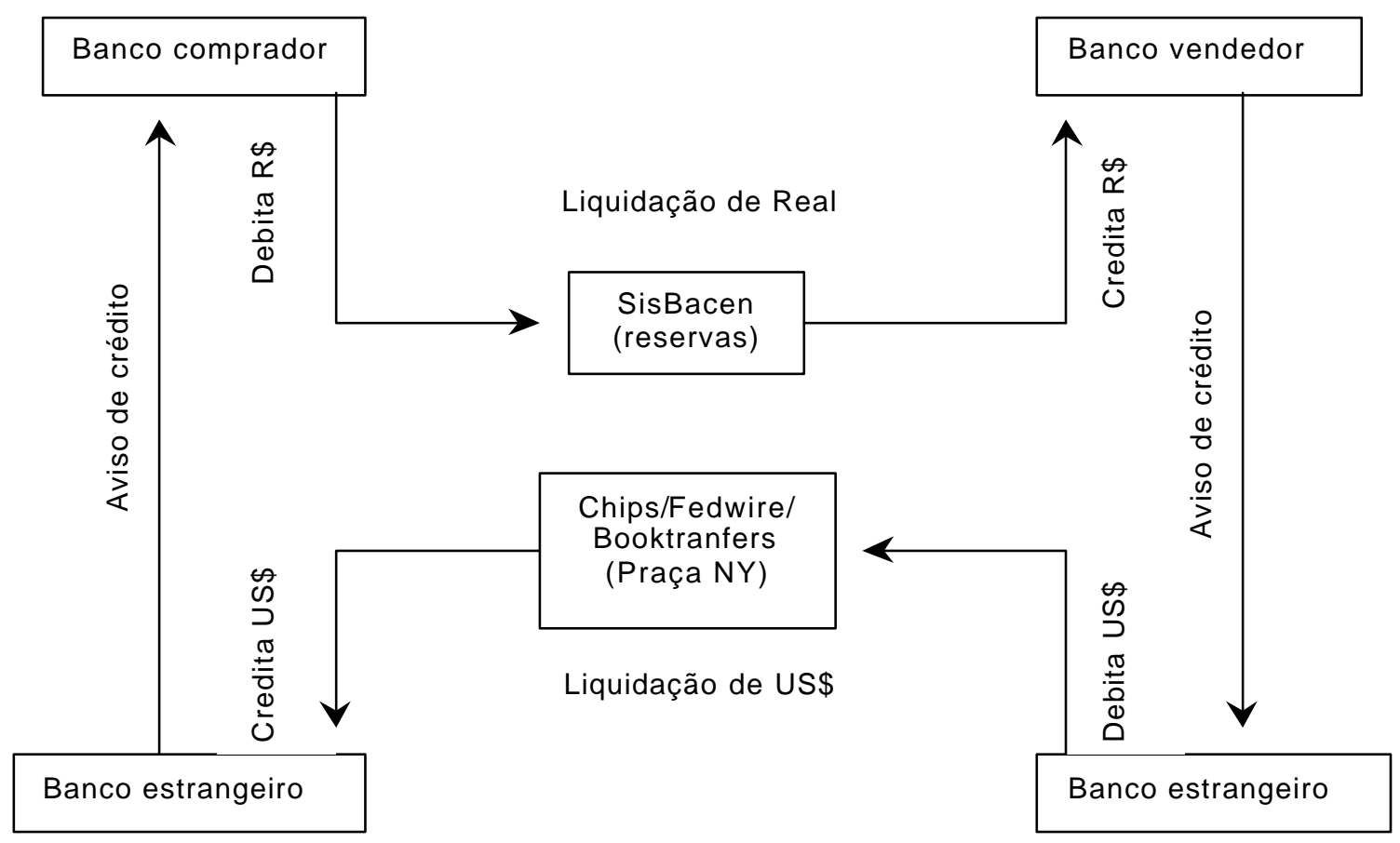

Figura 7 - Liquidação da moeda nacional e estrangeira.

Fonte: Garófalo filho (2000) 


\subsection{Riscos}

Segundo BACEN (2000b), risco é a "probabilidade de ocorrência de fatores adversos æ̀ expectativas esperadas". Aplicando esse conceito aos atos, fatos e ações econômicas pode-se definir o risco como o "grau de incerteza quanto àdisponibilidade de um valor no futuro". Nas transações cambiais as categorias e fontes de riscos mais importantes foram analisadas nos Relatórios Angell e Lamfalussy (BIS, 2002d) e segundo Fujiki et al (1999) os mais importantes são:

Risco de crédito: É o grau de incerteza de uma das partes de uma operação sobre o integral cumprimento da obrigação contratual por sua contraparte, ou seja, o risco de a contraparte não liquidar uma obrigação por seu valor total no vencimento. Esse tipo de risco refere-se a empréstimos, transferências financeiras, cumprimento de garantias, aceites e investimentos. De modo geral esse risco está associado à insolvência da contraparte. $\mathrm{O}$ risco de crédito pode ser decomposto em duas partes: risco de custo de reposição, que é função da volatilidade e risco de principal, que é o risco de perda da moeda entregue ou do valor relativo ao pagamento feito em função do contrato de câmbio, antes de se detectar a situação de falta de pagamento.

Risco de liquidez: Existe quando há uma impossibilidade momentânea de se cumprir uma obrigação financeira e pode ser definido como o grau de incerteza de uma das partes de uma operação sobre o cumprimento da obrigação contratual por sua contraparte. Esse risco se associa à probabilidade de ocorrência de um atraso no recebimento de um certo valor econômico, em relação a uma data contratada, recebendo-o em qualquer data posterior.

Risco Operacional: Refere-se à probabilidade de ocorrências adversas na disponibilidade de valores, devido a falhas no desempenho das funções dos sistemas de suporte e de prestação de serviços ao mercado considerado. Segundo Duarte Júnior (2002) as ocorrências mais importantes que envolvem tal risco dizem respeito a falhas nos controles internos e na estrutura de gestão das instituições diretamente envolvidas. Essas falhas podem vir a causar perdas financeiras decorrentes de erros, fraudes ou mau desempenho, seja por abuso de autoridade, seja devido à condução incorreta dos negócios.

Risco Legal: É a probabilidade de que falhas, omissões ou incerteza na estrutura legal venham causar riscos de crédito ou de liquidez. Esse risco inclui 
também a probabilidade de que um aconselhamento de natureza legal inadequado ou fundamentado em documentação incorreta venha a ocasionar uma redução no valor de ativos ou um aumento nas exigibilidades.

Risco de Mercado: Está relacionado com a probabilidade de perdas financeiras originadas de um movimento conjugado de variáveis econômicas, tais como juros, taxas de conversão de moedas e cotação de ativos ou derivativos objeto de negociação ou de prestação de garantias. Um tipo específico e comum desse risco existente na atividade bancária é o cambial, decorrente da postura de market marker, cotando taxas de conversão para seus clientes contra a tomada de posição no mercado de moeda. Se ele não for tratado, pode levar aos chamados second round effect (efeito dominó - ocorre se a inadimplência de um participante resultar na inadimplência de suas contrapartes) e ao replacement loss ( custo de reposição ocorre quando um participante tem que substituir, a preços de mercado, um contrato não honrado por uma contraparte inadimplente).

Registra-se no cenário internacional vários casos de bancos inadimplentes que geraram perdas aos participantes com os quais foram realizadas transações. Os mais conhecidos são citados em BIS (2002b) e entre eles temos o caso do Bankhaus Herstatt (pequeno banco alemão, ativo no mercado de câmbio) que, em 26/06/1974 teve sua licença caçada pela autoridade financeira local. Essa autoridade financeira ordenou a liquidação durante o horário bancário, após o fechamento do sistema de pagamentos interbancários alemão. As contrapartes com as quais ele havia fechado negócio durante aquele dia já tinham efetuado pagamentos irreversíveis em marco alemão. Como a maioria das operações eram day trade, seriam liquidadas no mesmo dia, em mercados diferentes e com fuso horário diferente. Quando a notícia da liquidação do banco chegou em Nova lorque foram suspensos os pagamentos em dólares que sairiam da conta do banco. Consequentemente, aqueles bancos que já haviam feito os pagamentos em marco alemão ficaram 100\% a descoberto e os bancos que fecharam contratos a termo com o Herstatt para vencimentos futuros obtiveram prejuízos ao recolocar o contrato no mercado, também incorrendo em perdas os bancos que possuíam depósitos junto àquele banco.

Outro caso de destaque ocorreu com o Bank of Credit and Commerce International em 05/06/1991, data em que esse banco foi fechado pelos agentes reguladores de sete países diferentes após serem descobertas fraudes causadas por 
alguns dos seus mais importantes executivos. Segundo "The Many facades" (1991), entre essas fraudes existiam operações triangulares com as filiais de Luxemburgo e Ilhas Cayman, paraísos fiscais onde empréstimos de origem duvidosa eram resgatados com depósitos fictícios.

Um tipo de problema que pode ser motivado pelo receio do risco de principal é o gridlock, caso da corretora norte-americana Drexel Burnham Lambert (DBL). Em fevereiro de 1990 ela decretou falência em decorrência de problemas de liquidez. O Banco da Inglaterra se viu obrigado a intervir como mediador das negociações, em função dos problemas gerados pela Drexel Burnham Lambert Trading (uma de suas subsidiárias em Londres). O Banco da Inglaterra passou a exigir da DBL evidência de sua solvência, só creditando a conta da DBLT após a confirmação do crédito à contraparte dos negócios firmados por ela.

\subsection{Funcionamento do novo sistema de pagamentos na ausência de uma Clearing}

Para ressaltar a importância de uma Clearing é interessante verificar como funcionaria o atual mercado sem a sua existência (considerando-se a reformulação na administração da reserva bancária pelo BACEN).

Contratação da Operação: Ocorreria em D+0.

Registro de Operação: Também ocorreria em D+0 e seria feita operação por operação pelos computadores do BACEN, com o banco comprador informando ao BACEN a intenção de compra e o banco vendedor confirmando ou não a venda de moeda.

Liquidação da Operação: A liquidação da operação ocorreria em D+N. A liquidação da moeda nacional se basearia no Sistema de Transferência de Reservas (STR). O banco comprador autoriza o débito no BACEN, mas se este banco não possuir saldo, a transação não se efetiva e entra em uma "fila de espera". Novo teste verificando a existência de saldo é feito e, se novamente não possuir saldo, o BACEN devolve a ordem ao banco comprador ficando o risco com o banco vendedor, que não recebeu o montante de moeda nacional a que tinha direito. Já a liquidação da moeda estrangeira ocorre ao longo do dia, com o banco vendedor emitindo uma ordem de pagamento (SWIFT) ao banco correspondente no exterior. Se o banco vendedor não 
possuir saldo, as Clearings (Chips, Fedwire, Booktransfers) devolvem a ordem de pagamento ao banco de origem, ficando o risco da operação com o banco comprador, que já pode ter efetuado o pagamento em moeda nacional e no entanto não recebeu a moeda estrangeira comprada.

Pelas novas regras do SPB, o BACEN não aceita débitos a descoberto nas contas de reserva e a ausência de uma Clearing só aumentaria o risco dos participantes no mercado interbancário. Nesse sistema, um banco, ao vender moeda estrangeira a outro, só se sente confortável em efetuar a transferência dessa moeda após ter recebido os reais correspondentes pelo STR. Da mesma forma, o banco comprador da moeda estrangeira somente transfere os reais correspondentes após receber a moeda comprada.

A inexistência de uma Clearing no novo SPB causa vários outros impactos sobre o mercado de câmbio. Todos eles gerando uma concentração do mercado interbancário, geralmente nos bancos mais fortes, devido ao aumento do risco de crédito das operações. Soluções de mercado para se lidar com os riscos sempre existirão, mas a um custo que pode ser inviável tanto para o mercado, quanto para a sociedade ${ }^{5}$.

\subsection{Comparação dos modelos de Clearings de câmbio existentes}

Aqui estão apresentados três modelos de Clearings de câmbio e as principais diferenças entre eles.

\subsection{1 $1^{\circ}$ Modelo: Fluxo}

Baseado no fluxo de caixa das operações realizadas, esse sistema efetua o netting de todas as operações dos participantes. Esse netting é o montante que cada banco deve pagar e receber nas moedas passíveis de liquidação por intermédio da câmara. No dia de liquidação, ocorrendo insolvência, o sistema não leva em conta as operações dos bancos insolventes e calcula novamente a posição líquida de cada

\footnotetext{
${ }^{5}$ Essas informações foram extraídas de conversas com dirigentes e funcionários do Banco Central do Brasil e da Bolsa de Mercadorias e Futuros.
} 
participante. Esse modelo pertence à classe dos sistemas de pagamento inseguros sendo considerado extremamente arriscado.

Um exemplo ilustra o potencial de risco embutido nesse tipo de sistema. Suponha-se que 0 banco $X$ tenha efetuado duas operações com diferentes contrapartes. Esse banco compra US\$10MM do banco A e vende US\$10MM ao banco B para a mesma data de liquidação. No dia de liquidação, verifica-se que o banco A não entregou o montante de dólares que devia e ficou insolvente. O sistema recalcula as novas posições dos bancos adimplentes. O banco $\mathrm{X}$, que estava zerado, agora precisa entregar à Clearing US\$10MM, sob o risco de ele mesmo ser considerado inadimplente, caso não pague. Essa situação poderia gerar uma cadeia de inadimplências e problemas de liquidez que contaminariam não só os bancosmembros da câmara, como também o resto do mercado.

Assim, este é um modelo que expõe ao risco os próprios membros da Clearing e as instituições financeiras fora de seu sistema de liquidação.

\subsection{2 $2^{0}$ Modelo: Com chamadas de garantias, mas com repartição de perdas entre participantes}

Por "chamadas de garantias" entende-se o uso dos ativos entregues à Clearing para cobrir eventuais inadimplências, também chamado de loss sharing/survivors pay principle. Nesse modelo, caso haja inadimplência de um ou mais participantes, as eventuais perdas produzidas serão divididas entre todos os bancos "sobreviventes". Por bancos "sobreviventes" entendam-se todos os adimplentes do sistema. É importante ressaltar que a repartição de perdas não se dá apenas entre os bancos adimplentes que operaram com inadimplentes, mas sim entre todos os sobreviventes do sistema.

Esse tipo de mecanismo leva a riscos de moral hazard (risco moral) e de free rider (carona), aumentando o risco global da câmara. O risco de moral hazard ocorre quando os participantes diminuem o nível de monitoramento do risco de crédito de suas contrapartes, posto que qualquer perda financeira decorrente de default será dividida entre todos os participantes. $O$ risco de free rider origina-se do incentivo que cada participante tem de elevar a própria alavancagem (através do aumento do número de contratos) pelo receio de que outros participantes estejam fazendo $o$ 
mesmo, haja vista que tanto participantes agressivos quanto participantes conservadores dividem a conta em caso de um default. Por isso, esse modelo funciona bem apenas em condomínios pequenos e constituídos de participantes homogêneos.

Um exemplo desse modelo é o projeto da Multinet, do qual fazem parte 20 bancos internacionais de grande porte, com a mesma capacidade de pagamento e compondo um grupo homogêneo. Outro exemplo, fracassado, desse modelo foi verificado no mercado de câmbio alemão. O banco central da Alemanha propôs esse modelo aos bancos alemães, mas a proposta foi rejeitada, devido aos problemas citados anteriormente. Os bancos alemães não concordaram em assumir prejuízos e problemas provenientes de riscos assumidos por outras instituições.

\subsection{3 $3^{0}$ Modelo: Com chamadas de garantias, mas com repartição de perdas entre os participantes que operaram com inadimplentes}

Semelhante ao anterior, este modelo apresenta chamadas de garantias para cobrir eventuais variações da taxa de câmbio, além de chamadas de garantias adicionais. Ocorre também a fixação de limites de compra e venda por participante. A principal diferença entre este modelo e o anterior é que, em caso de eventuais prejuízos, estes serão repartidos apenas entre os participantes que operaram com o participante inadimplente.

Essa divisão respeita critérios de volume operado e de resultado ${ }^{6}$. Dessa forma, há a eliminação do risco de moral hazard e do risco de free rider, uma vez que cada participante corre risco apenas com suas próprias contrapartes e não com as contrapartes de outros participantes. Assim, cada participante é estimulado a monitorar cuidadosamente suas posições. Ademais, como no modelo anterior, não há propagação de riscos para fora do sistema.

\footnotetext{
${ }^{6}$ Por critério de resultado, entenda-se que apenas as operações "perdedoras", isto é, operações que, quando marcadas a mercado, resultam em custo de reposição, contribuem para cobrir o prejuízo causado pelo inadimplente.
} 


\subsection{Projeto de Clearing de câmbio da BM\&F}

Aproveitando toda a sua estrutura e experiência, a BM\&F propôs ao BACEN um projeto de desenvolvimento, implantação e administração de uma câmara específica para a compensação e liquidação de operações de câmbio no mercado interbancário brasileiro, no contexto do novo SPB.

Um ponto de extrema importância no projeto da Clearing de câmbio é a adaptação de modelos internacionais à realidade brasileira. A Clearing apresenta sistemas de operação distintos, que possibilitam a participação de todas as instituições do mercado interbancário, sendo desenvolvida de modo que pudesse oferecer vários serviços em termos de garantia (de principal, de volatilidade e de liquidação total da operação). Todos esses serviços exigem certos limites operacionais, garantias, limites de crédito e disponibilidade de linhas de crédito junto à Clearing para que se possa liquidar qualquer operação.

Segundo BM\&F (2002c) a Clearing também apresenta poder de auto-regulação e fiscalização das operações, podendo rejeitar as operações que não se enquadrem nos padrões de normalidade do mercado. Ela pode adotar as medidas necessárias para a pronta liquidação das operações, inclusive na ocorrência de inadimplência de participantes, não permitindo que estas ocorrências venham a prejudicar o bom andamento do mercado.

Dada a heterogeneidade dos bancos que operam no mercado de câmbio interbancário brasileiro, esse projeto prevê a existência de diferentes sistemas de liquidação quanto ao depósito de garantias. De acordo com a proposta da BM\&F, ao se habilitar junto à câmara, cada instituição participante tem um limite operacional, definido de acordo com a sua capacidade de honrar os pagamentos e seu perfil no mercado de câmbio.

De acordo com BM\&F (2002d) a Clearing de câmbio trata diferentemente as instituições bancárias de acordo com a saúde financeira de cada uma. Aos bancos com excelentes condições operacionais e de liquidez para honrar seus compromissos (independente do pagamento de uma ou mais de suas contrapartes) a Clearing intervêm reduzindo o custo operacional, pois opera com a liquidação única de todas as suas operações, eliminando assim o risco de crédito com relação ao principal (não correndo o risco de pagar sem receber). Alguns bancos conseguem suportar o risco de 
volatilidade da moeda comprada (caso ocorra a inadimplência da contraparte da operação), mas que não dispõem de uma linha de crédito imediata na moeda comprada para cumprir seus compromissos. Para eles, a Clearing atua centralizando a liquidação de suas operações, garantindo aos mesmos que não correrão o risco de pagar sem receber e com a certeza de que, caso ocorra a inadimplência da contraparte, haverá a devolução do dinheiro pago na moeda comprada.

Quanto aos bancos menores (aqueles que não dispõem de limites de crédito junto aos bancos médios e grandes), a Clearing atua garantindo integralmente as suas operações para que eles possam participar do mercado. Essa garantia deve se dar em relação ao principal, àvolatilidade e ao âmbito de liquidação na moeda transacionada.

Assim, o projeto desenvolvido, proposto e implantado pela BM\&F permite aos operadores participar das definições dos riscos e dos custos que estão dispostos a correr quando contratam uma operação. Nesse projeto, várias medidas foram adotadas para reduzir os riscos.

Quanto ao risco legal, a principal medida adotada para reduzi-lo foi a organização de todo o projeto da Clearing de acordo com uma legislação específica para o novo SPB. Algumas dessa normas são: Lei n 10.214 (ver anexo 2), de 27/03/2001 (dispõe sobre o SPB), Resolução do Conselho Monetário Nacional n ${ }^{0} 2.882$ de 30/08/2001 (dispõe sobre as câmaras de compensação e liquidação), Circular do BACEN n 3.057 de 31/08/2001 (dispõe sobre câmaras de compensação e liquidação), Lei $n^{0} 4.595$ de 31/03/1964 (dispõe sobre o mercado de câmbio brasileiro), Resolução $n^{0} 1.690$, de 18/03/1990, do Conselho Monetário Nacional (permite a contratação de operações de câmbio a taxas livremente pactuadas, dentre outras providências) e a Circular n 1.815 , de 17/09/1990, do BACEN (dispõe sobre os procedimentos para a celebração de operações interbancárias de câmbio via Sisbacen).

Essa leis, resoluções e normas dão um arcabouço legal à Clearing de câmbio para que a mesma consiga funcionar adequadamente, dando liberdade para que medidas de controle da liquidação dos contratos sejam tomadas de forma correta e sem maiores empecilhos.

No que se refere aos custos, os bancos habilitados a negociar através da Clearing de câmbio repassam um percentual fixo do volume total do contrato negociado. Esses custos dividem-se em básicos (custos de utilização dos sistemas de processamento convencionais da Clearing, como registro, compensação e liquidação) 
e extras (custos de serviços extraordinários solicitados pelos participantes, como registro de operações por outros meios de comunicação que não os convencionais e emissão de extratos adicionais ou em padrões diferentes daqueles definidos pela Clearing).

Os custos das operações registradas diretamente pelos bancos (comprador e vendedor) são determinados com base no percentual de 0,0009\% (nove décimos de milésimo por cento), sobre o somatório dos valores, em moeda nacional, de todas as operações registradas nos sistemas da Clearing por participante. Com isso, para cada US\$ 1 milhão negociado o investidor deve repassar à Clearing de Câmbio US\$ 9,00 referentes a custo das operações. As sociedades corretoras autorizadas a intermediar operações de câmbio possuem um custo de 0,0006\% (seis décimos de milésimo por cento) sobre o valor em moeda nacional da operação registrada, para cada uma das partes envolvidas (banco comprador, banco vendedor e sociedade corretora).

Esse modelo de clearing adotado pela BM\&F não é o único existente, outros modelos similares nas bolsas também existem, apesar de alguns detalhes particulares de cada um. Um exemplo a ser destacado são os das bolsas americanas. Nelas o controle das operações é feito em cada corretora, de modo que a bolsa não toma conhecimento e não garante as posições do cliente com a corretora.

Segundo Silva Neto (1999), grande parte das margens que são depositadas pelos agentes detentores de posição fica nas mãos da corretora e não com a bolsa. A lei americana intervém pedindo que estes recursos fiquem segregados dos da corretora. Na Chicago Board of Trade, a maior bolsa do mundo em número de contratos negociados, a câmara de compensação, diferente da câmara da BM\&F, é uma instituição independente da bolsa.

Fortuna (1999) expõe as duas principais câmaras de compensação da Europa, a Cedel (sediada em Luxemburgo desde 1970) e a Euroclear (sediada em Bruxelas desde 1968). Elas são concorrentes entre si e foram fundadas para suprir a necessidade do mercado europeu de se eliminar os riscos na liquidação das operações com Eurobonds. Estes riscos eram causados pela distância entre os países e pela diferença de uso horário e língua. Nessas câmaras de compensação a entrega dos títulos ocorre somente contra o recebimento da moeda, em um processo simultâneo. 


\section{METODOLOGIA}

O método de estudo de caso é uma poderosa ferramenta para os pesquisadores (Yin, 1989). Para Maximiano (2000), essa metodologia é, ao mesmo tempo uma forma de pesquisa (isto é, uma estratégia de formação de conhecimento), uma forma de transmitir esse conhecimento (ou seja, um recurso educacional), além de uma forma de elaboração de princípios gerais. Ele conclui que a metodologia de estudo de caso é um recurso para a produção teórica.

Segundo Yin (1989), o estudo de caso é uma análise empírica na qual se utilizam múltiplas fontes de dados e que essencialmente busca:

$\Rightarrow$ investigar um fenômeno contemporâneo dentro de um contexto da vida real;

$\Rightarrow$ realizar uma análise quando as fronteiras entre o fenômeno e esse contexto não são evidentes.

Várias críticas são feitas sobre esse método de pesquisa, como por exemplo: falta de rigor, influência do investigador (falsas evidências, visões viesadas), fornecimento de pouquíssima base para generalizações e trabalhos extensos que demandam muito tempo para serem concluídos.

Yin (1989) responde a essas críticas, dizendo que há diversas maneiras de se evidenciar a validade e a confiabilidade do estudo realizado. Para ele, um estudo de caso procura generalizar proposições teóricas (modelos) e não proposições sobre populações (nesse sentido os estudos de casos múltiplos e as reaplicações de um mesmo trabalho com outras amostras procuram indicar o grau de generalização das proposições) e por fim, nem sempre se faz necessária a utilização de técnicas de coleta de dados que consumam muito tempo.

Ainda segundo esse mesmo autor, a essência principal de um estudo de caso é tentar esclarecer uma decisão ou um conjunto de decisões, respondendo questões 
como; por que elas foram tomadas? Como foram implementadas? e quais os resultados alcançados?

Dentre as diversas aplicações de um estudo de caso, tem-se:

$\Rightarrow$ Explicar ligações causais em situações da vida real que são muito complexas para tratamento através de estratégias experimentais ou de levantamento de dados;

$\Rightarrow$ Descrever um contexto de vida real no qual uma intervenção ocorreu;

$\Rightarrow$ Avaliar uma intervenção em curso e modificá-la com base em um Estudo de Caso ilustrativo;

$\Rightarrow$ Explorar aquelas situações nas quais a intervenção não tem clareza no conjunto de resultados.

Quanto às fontes de "dados" (evidências) para se conduzir uma pesquisa de estudo de caso, podem ser adotados documentos (cartas, memorandos, comunicados, propostas, relatórios, cronogramas, jornais, etc), entrevistas (relato verbal sujeito a problemas de viés, recuperação de informações e articulação imprecisa) além de uma observação direta do fenômeno em estudo. A utilização de várias dessas fontes permite o desenvolvimento da investigação em diversos aspectos em relação ao mesmo fenômeno, tornando as conclusões mais convincentes e apuradas.

Este trabalho enquadra-se nesta definição, pois estuda a observação e o relato de um fenômeno contemporâneo (a implantação da Clearing de Câmbio da BM\&F) dentro de um contexto no qual está inserido (a reestruturação do Sistema de Pagamentos Brasileiro).

Neste capítulo são evidenciados os aspectos metodológicos propostos para a análise do problema. Para se alcançar os objetivos serão necessárias a utilização de duas metodologias distintas: uma pesquisa exploratória (análise qualitativa) e uma pesquisa quantitativa.

A escolha da Clearing de Câmbio da BM\&F como o caso a ser estudado baseou-se no fato desta ter passado por um longo período de testes e por ser de extrema importância dentro do contexto do novo Sistema de Pagamentos Brasileiro. 


\subsection{Análise qualitativa}

Segundo Van Maanen (1983) a metodologia da análise qualitativa é constituída por um conjunto de técnicas interpretativas (e também positivistas, quando se trata de estudos de caso) que têm por objetivo retraçar, decodificar ou traduzir fenômenos sociais naturais, visando-se obter elementos relevantes para a descrição ou explicação destes fenômenos.

De acordo com Lee (1989), o mais importante na análise qualitativa é que o pesquisador, a partir dos dados obtidos, possua um conjunto de informações que lhe permitam dar um sentido àquilo que está sendo proposto como estudo, convencendo o leitor da pertinência e veracidade de sua análise, através da organização de cadeias de evidência.

A análise de dados em pesquisas qualitativas normalmente compreende três etapas: a codificação dos dados, a sua apresentação de forma mais estruturada e a análise propriamente dita (Silverman, 2001). A codificação e a análise são complexas porque baseiam-se, em geral, em palavras e rão em números. Por sua natureza, palavras são mais densas que números, possuindo vários sentidos e dando mais margem de interpretação, além de serem obtidas em grandes quantidades. Para extrair o máximo dos dados qualitativos, Van Maanen (1983) recomenda uma codificação das anotações e das observações, na qual os códigos significam categorias representativas da questão de pesquisa e dos temas e conceitos importantes.

A análise dos dados propriamente dita consiste na etapa mais difícil e exigente da pesquisa qualitativa, pois as estratégias e técnicas utilizadas podem apresentar uma enorme diversidade. Yin (1989) propõe duas estratégias gerais de análise, o uso de bases teóricas e o desenvolvimento de uma descrição do caso. Ele também propõe três modos de análise, a procura de padrões que adequam-se ao modelo de pesquisa (pattern-matching), a construção de uma explicação (explanation building) e a análise dos dados quantitativos obtidos (normalmente a título de complementação).

Embora exista uma clara distinção entre a obtenção de dados e a sua análise, esta distinção é problemática para muitos pesquisadores de métodos qualitativos. Os pressupostos do pesquisador afetam a coleta de dados e dependendo da forma como estes foram obtidos, os resultados serão alterados. Enfim, os dados afetam a análise de uma forma significativa, assim como a análise afeta os dados. Existem diferentes 
abordagens para se obter, analisar e interpretar os dados qualitativos. A linha comum é que todos os modos qualitativos de análise relacionem-se, primeiramente, com análise textual, seja verbal ou escrita (Myers, 1997).

\subsection{Pesquisa quantitativa}

Estudos realizados por Kotler \& Fox (1994) mostram que após definido o problema a ser pesquisado e realizada a análise qualitativa, o pesquisador deve proceder a uma análise quantitativa, com o objetivo de mensurar as magnitudes das suas hipóteses.

Seguindo esse princípio foram obtidos os dados referentes ao mercado interbancário de câmbio mostrando as mudanças que ocorreram com a implantação da Clearing. O período analisado compreende os meses de Janeiro de 2001 a Julho de 2002, incorporando inclusive os 4 primeiros meses de existência do novo Sistema de Pagamentos Brasileiro. Estudou-se a evolução do mercado de câmbio durante o referido período, buscando-se estabelecer uma relação que colocasse em evidência a implantação do novo sistema de pagamentos.

Junto à BM\&F foram obtidos os dados sobre a evolução das operações cursadas pela Clearing de câmbio durante o período de 22/04/2002 à 30/09/2002. Esses dados compreendem o volume contratado e a quantidade de operações liquidadas tanto para $\mathrm{D}+1$ quanto para $\mathrm{D}+2$. De posse desses dados foi mostrado como tem sido o papel da clearing dentro do novo SPB.

Finalmente, foi comparado o total das operações e o volume negociado tanto pelo BACEN (através do Sisbacen) quanto pela BM\&F (através da Clearing de Câmbio). Nesse ponto também foi destacada a participação da Clearing no mercado interbancário. Uma simulação, com a ausência da clearing entre os meses de abril e setembro de 2002 foi realizada, mostrando como o mercado teria desembolsado um maior volume de recursos e em consequência aumentado os riscos sistêmicos, caso a clearing de câmbio não existisse nesse período. 


\subsection{Dados}

O principal período analisado é aquele que vai de 22/04/2002 a 30/09/2002 englobando os primeiros meses da implantação do novo SPB e da Clearing de Câmbio.

Para alcançar os objetivos propostos, as variáveis observadas e analisadas são:

$\Rightarrow$ participação dos agentes (comercial, financeiro e BACEN) no mercado de câmbio,

$\Rightarrow$ Evolução do STR,

$\Rightarrow$ Volume contratado pela BM\&F para liquidação em $D+1$ e $D+2$,

$\Rightarrow$ Volume financeiro liquidado pela Clearing de Câmbio,

$\Rightarrow$ Volume total do mercado interbancário de câmbio negociado no Sisbacen e na BM\&F para liquidação em $D+1$ e $D+2$ e

$\Rightarrow$ Participação da Clearing de Câmbio no mercado interbancário de Câmbio.

Esses dados foram obtidos junto ao Banco Central do Brasil e junto à Clearing de Câmbio da Bolsa de Mercadorias e Futuros. 


\section{RESULTADOS E DISCUSSÃO}

\subsection{Introdução}

Neste capítulo mostram-se quais os impactos da implantação do novo SPB no mercado de câmbio brasileiro e quais os principais efeitos da Clearing de Câmbio no mercado interbancário, procurando evidenciar a sua eficiência como instituição de compensação e liquidação de moeda.

\subsection{Efeitos do Novo SPB}

Como dito anteriormente, o mercado de moedas estrangeiras envolve três agentes: o comercial, o financeiro e o BACEN. A figura 8 mostra como foi a participação do agente comercial durante o ano de 2001 e os primeiros sete meses do ano de 2002. Verifica-se que o número de contratos de exportação de moeda é inferior ao número de contratos de importação; entretanto, o valor das exportações de moeda sempre foram superiores ao valor das importações sugerindo contratos de exportação com valores bem maiores. Esse quadro não se modifica com a implantação no novo SPB, como se pode ver na mesma figura.

Na figura 9 tem-se a evolução do mercado primário financeiro; nele também se verifica um número bem maior de contratos enviados do que recebidos do exterior. $O$ valor desses contratos apresenta uma variação muito grande ao longo do período estudado, inclusive após o mês de abril de 2002, no qual o novo SPB já estava implantado. Não há, portanto, mudanças significativas nesse setor.

O mercado interbancário mostra-se como sendo o que apresenta um maior equilíbrio ao longo do tempo. Verifica-se pela figura 10 que o número de contratos de 
compra de moeda sempre foi muito parecido com o número de contratos de venda, sendo o valor desses contratos também muito equilibrados. Um ponto a ser destacado nesta figura é a comparação do período de abril a julho para os anos de 2001 e 2002. Observa-se no primeiro período cerca de aproximadamente 150 mil contratos negociados (compra e venda) enquanto em 2002 essa quantidade se reduz para aproximadamente 108 mil contratos.

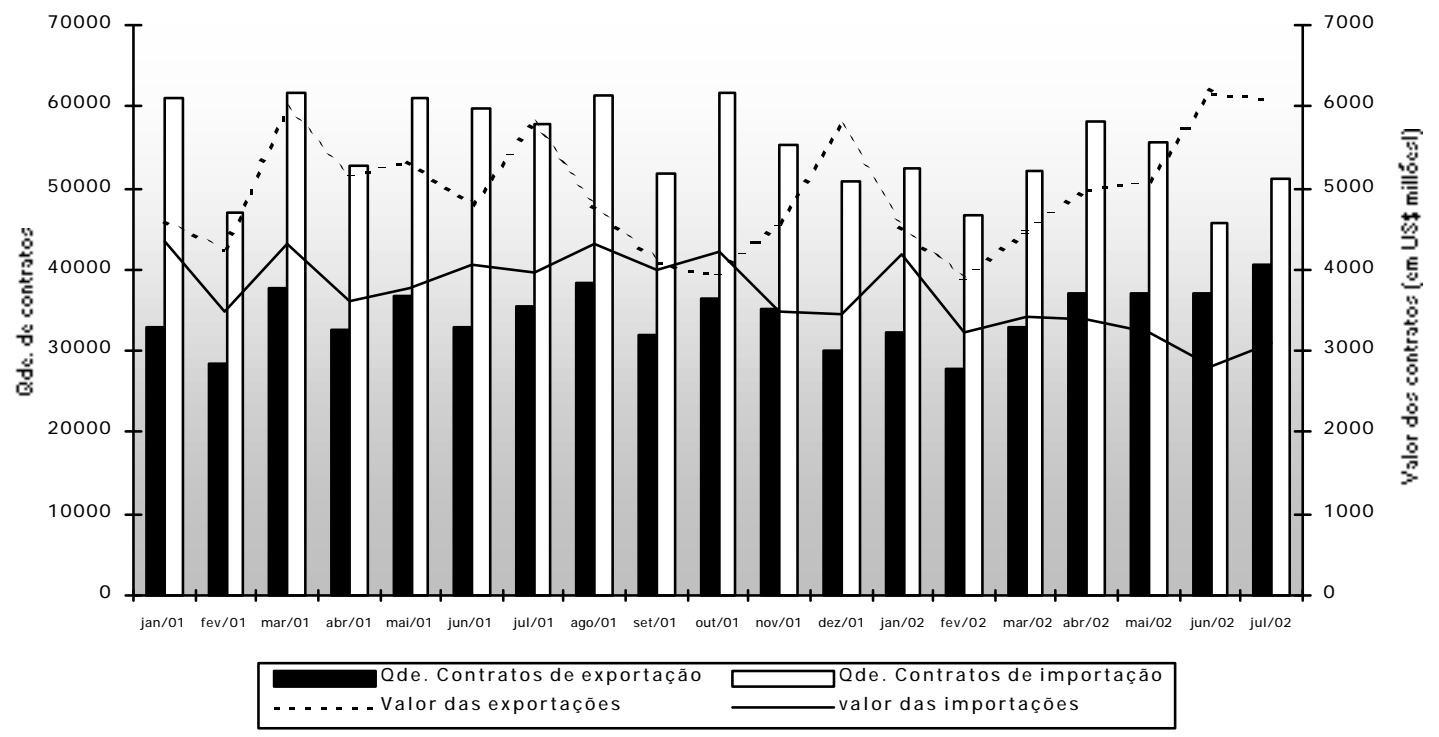

Figura 8 - Evolução do Mercado de Câmbio Primário Comercial no período de jan/2001 a jul/2002.

Fonte: BACEN (2002c)

Também é evidente a diferença no valor desses contratos. Enquanto entre os meses de abril e julho de 2001 foram negociados cerca de US\$ 448 bilhões, no mesmo período em 2002 (no qual a Clearing já estava operando) esse valor se reduziu para aproximadamente US\$264 bilhões. Na média, o valor de cada um desses contratos que era de US\$ 3 milhões passa a ser de US\$ 2,5 milhões após a implantação da Clearing. 


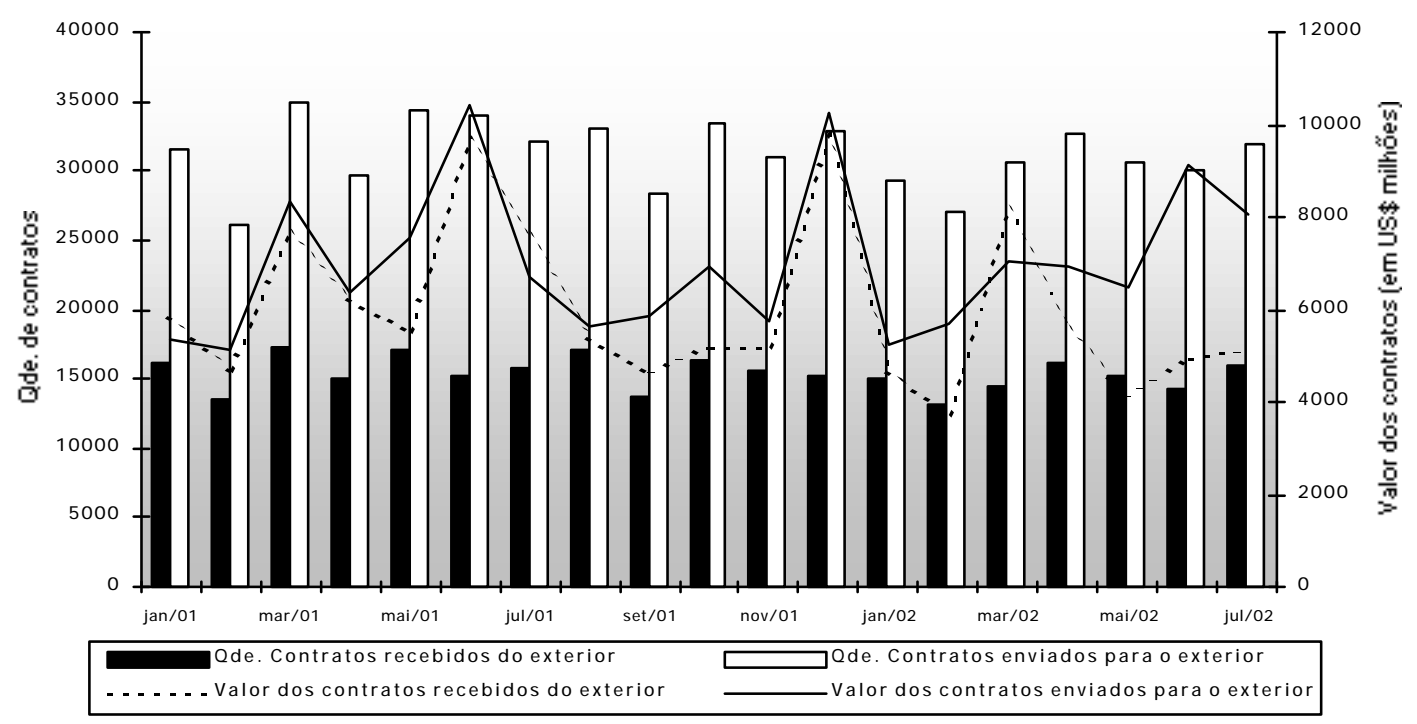

Figura 9 - Evolução do Mercado de Câmbio Primário Financeiro no período de jan/2001 a jul/2002.

Fonte: BACEN (2002c)

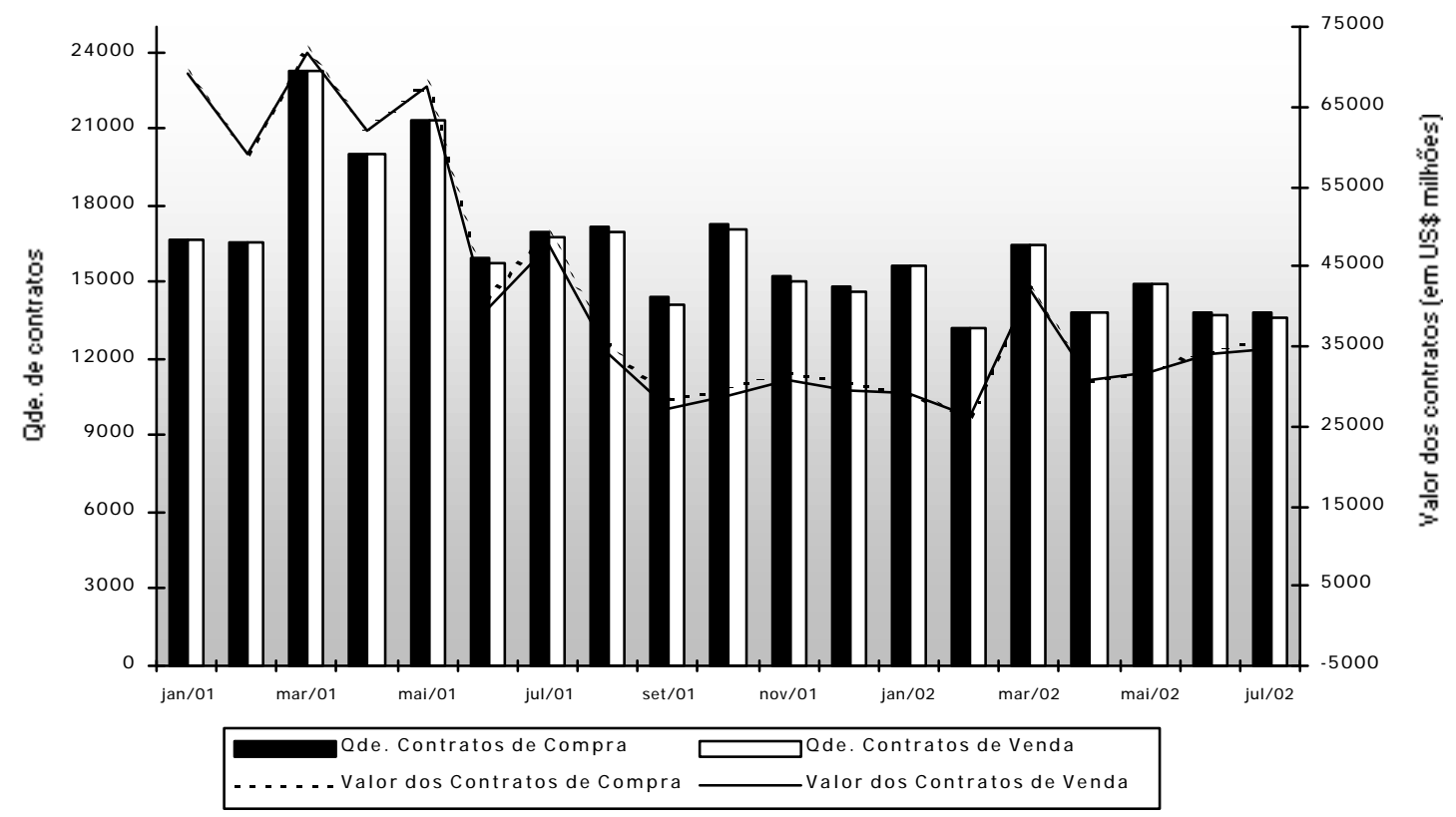

Figura 10 - Evolução do Mercado Interbancário de Câmbio no período de jan/2001 a jul/2002.

Fonte: BACEN (2002c) 
A evolução do STR nos primeiros meses está apresentada na figura 11. O giro total (quantidade de mensagens cursadas no STR, independente da existência ou não de pagamentos vinculados àmensagem) nesse novo sistema de transferência no mês de maio estava em torno de 20.000 contratos por dia. Já a quantidade de pagamentos (eventos que geram, efetivamente, débitos ou créditos financeiros para os participantes emissores e destinatários da mensagem) estava em torno de 8.000 contratos por dia e a quantidade de TED era pouco mais de 2.000 transferências diárias. À medida que o BACEN reduzia o valor para se efetuar as transferências via STR, a quantidade de contratos aumentava.

Durante o mês de agosto, a quantidade de contratos que girava no STR atingiu o montante de 40.000, o total de pagamentos chegou aos 30.000 e as TED apresentaram um crescimento surpreendente, saltando de pouco mais de 2.000 para mais de 20.000 transferências diárias. Essa popularização dos mecanismos de transferência, estimulada pelo BACEN, aumentou não somente a quantidade de contratos, mas também o volume transacionado nesse novo sistema.

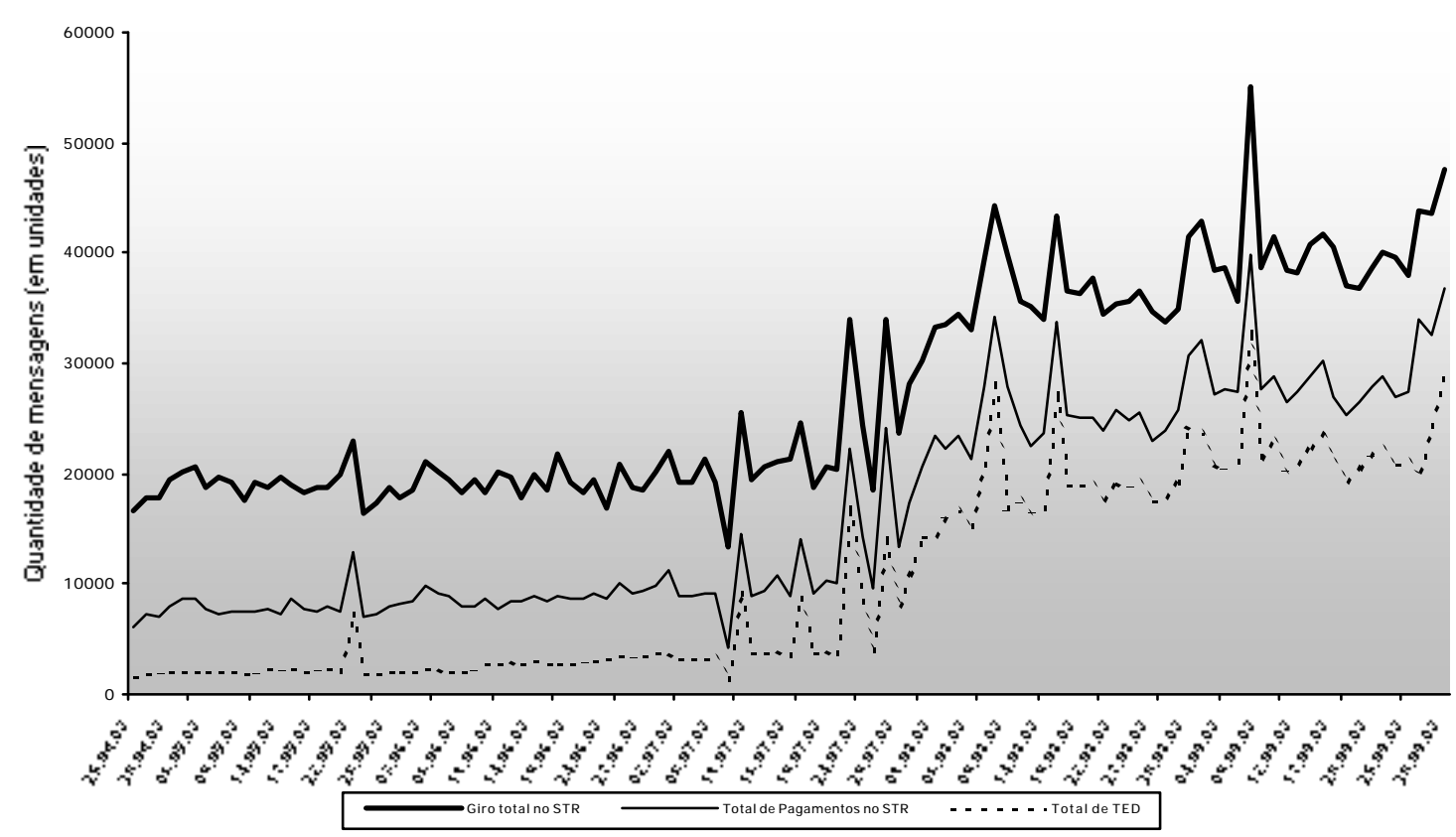

Figura 11 - Total de giro, pagamentos e transferências via TED realizadas pelo STR entre 22/04/2002 e 30/09/2002.

Fonte: BACEN (2002c) 
A figura 12 mostra que o volume transacionado em giro e pagamentos, apesar de algumas oscilações bruscas, tem apresentado uma tendência de crescimento contínuo desde o início do novo sistema.

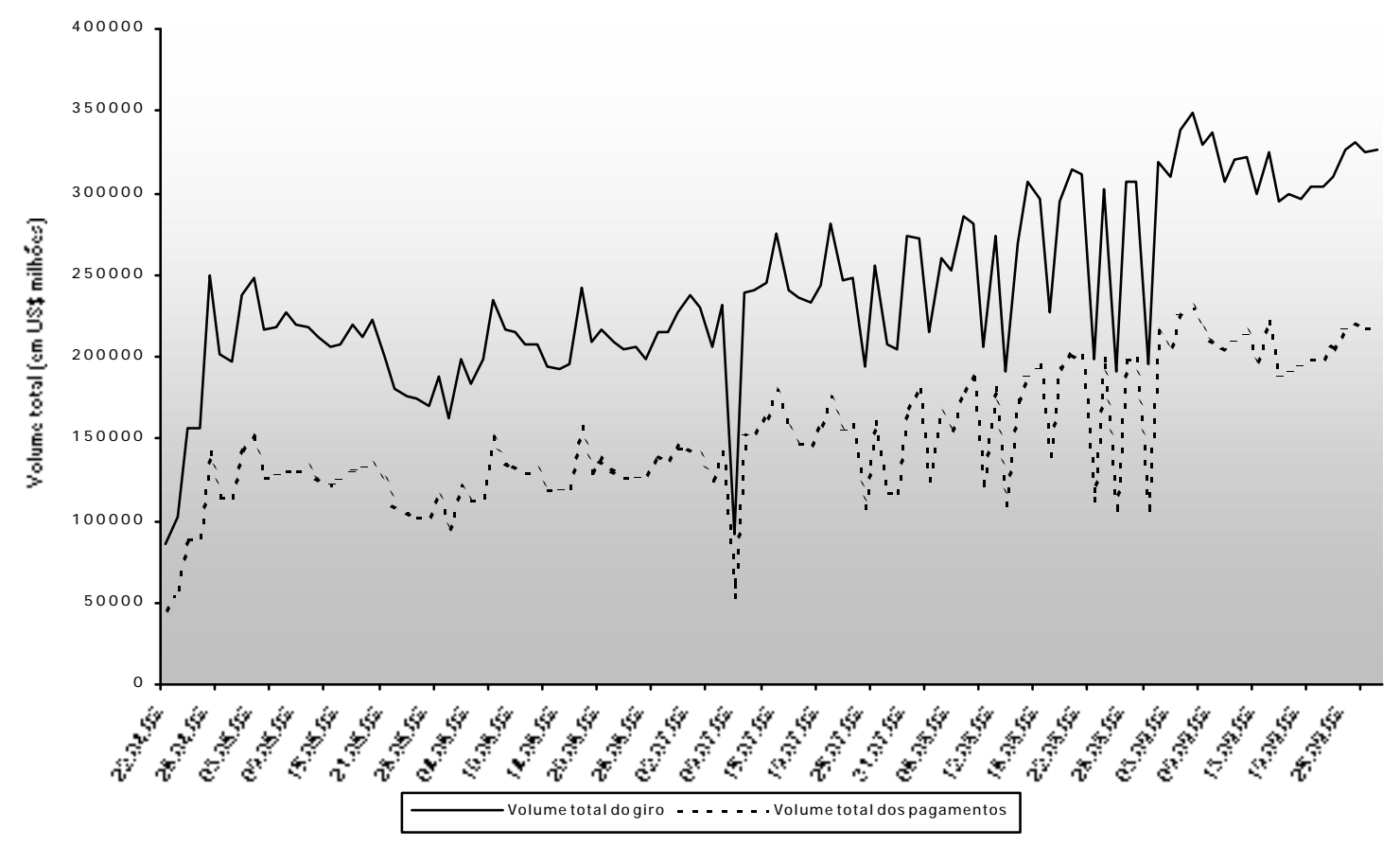

Figura 12 - Volume total do giro e dos pagamentos realizados pelo STR entre 22/04/2002 e 30/09/2002.

Fonte: BACEN (2002c)

\subsection{Clearing de Câmbio: Seu papel no novo SPB}

Desde que iniciou suas atividades, a Clearing de câmbio tem se mostrado cada vez mais sólida no mercado interbancário de câmbio. A análise a seguir procura mostrar sua importância e eficiência para as instituições que transacionam nesse mercado.

Negociando em D+1 e D+2 a Clearing tem conseguido girar um volume considerável de recursos. A figura 13 mostra a contratação para D+1. O maior volume que foi transacionado em um único dia foi mais de US $\$ 300$ milhões, mantendo-se uma média diária nos primeiros 5 meses em aproximadamente US\$ 61 milhões. No início da implantação desse novo sistema o mercado agia com cautela, mas começou a 
aumentar o número de negociações com o passar do tempo. Para $D+1$ essa quantidade chegou a atingir cerca de 29 operações em um único dia.

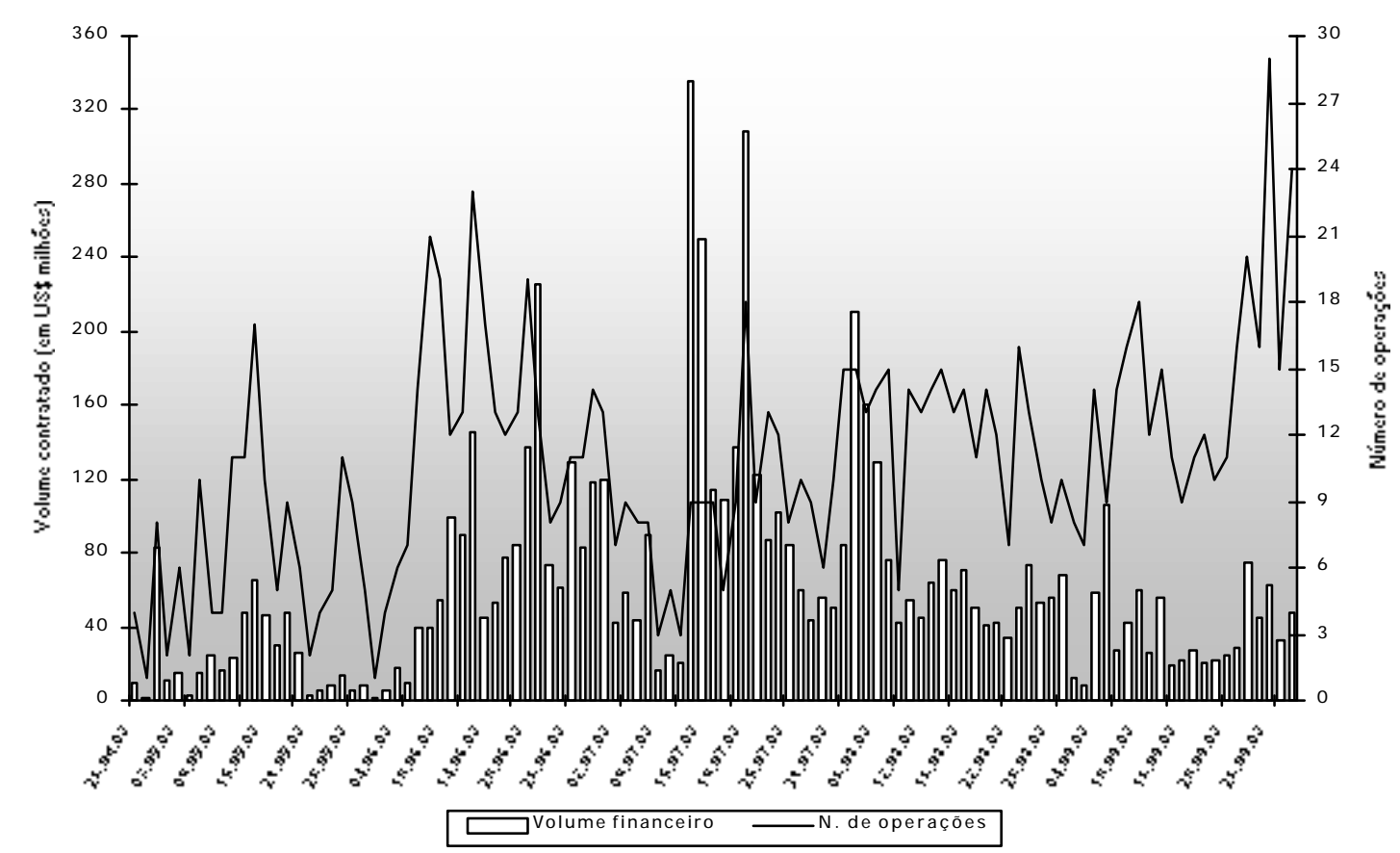

Figura 13 - Volume contratado pela BM\&F para liquidação em $D+1$ no período de 22/04/2002 e 30/09/2002.

Fonte: BM\&F (2002b)

No entanto, o grande movimento de operações na Clearing é para liquidação em D+2. Durante os cinco primeiros meses de funcionamento, a média diária de volume negociado foi de US\$ 460 milhões para uma quantidade média de 311 operações por dia. A figura 14 mostra como foi a evolução diária do volume contratado e da quantidade de operações na clearing para liquidação em D+2.

Trabalhando com o princípio de liquidação líquida, verifica-se na figura 14 que a Clearing de câmbio conseguiu cumprir seu principal objetivo: reduzir o volume efetivamente transacionado entre as instituições.

A figura 15 mostra o volume total (bruto) de moeda transacionado entre as instituições. Esse volume representa a quantidade de moeda que foi comprada e vendida nas operações entre os bancos. No entanto a maior parte desse montante não 
necessitou ser transferido entre os bancos, pois o modelo adotado pela Clearing é de Liquidação Líquida, transferindo-se somente o montante líquido dessas transações.

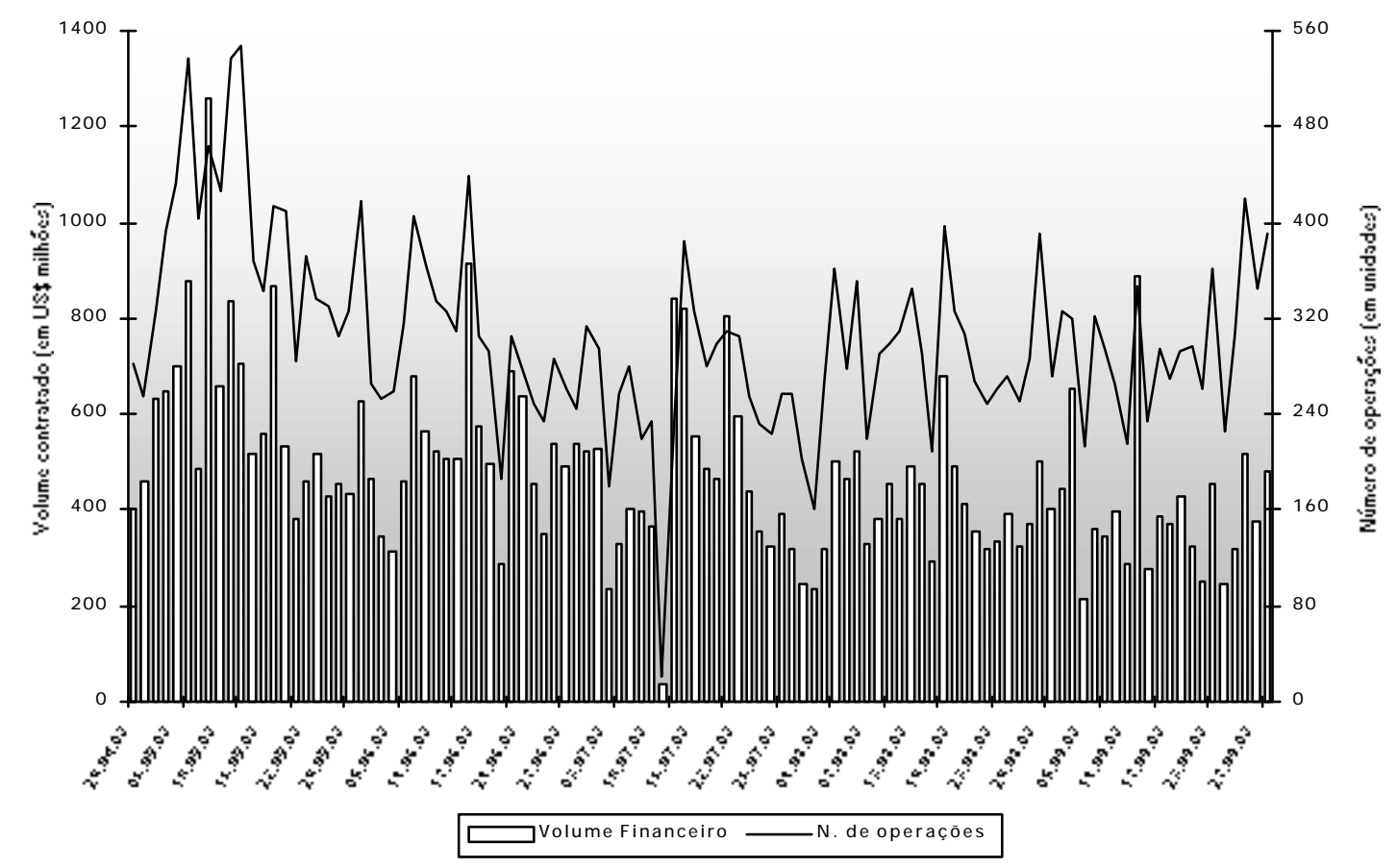

Figura 14 - Volume contratado pela BM\&F para liquidação em D+2 no período de 22/04/2002 e 30/09/2002.

Fonte: BM\&F (2002b)

O volume total (bruto) negociado pela clearing nos seus primeiros cinco meses foi de US\$120.919.433.720,38. No entanto o montante liquidado simplesmente por compensação foi de US\$103.665.111.376,64, ou seja, mais de $85 \%$ do volume total foi liquidado através da adoção do princípio de liquidação líquida. Apenas US $\$ 17.254 .322 .343,74$ foi efetivamente liquidado via movimentação financeira.

Fazendo uma comparação dessa situação com uma outra, hipotética, como se essas operações tivessem sido realizadas fora da clearing consegue-se entender 0 que ela representa em termos de redução do risco sistêmico.

O modelo de contratação adotado fora dos sistemas da clearing é aquele no qual as operações contratadas devem ser liquidadas individualmente e sem compensação. Ou seja, toda compra e toda venda realizada pelos bancos devem ser liquidadas isoladamente, através da entrega de reais $(R \$)$ e do recebimento de dólares 
(US\$) correspondentes à sua operação de compra, e da entrega de dólares (US\$) e recebimento de reais $(R \$)$ correspondente àsua operação de venda.

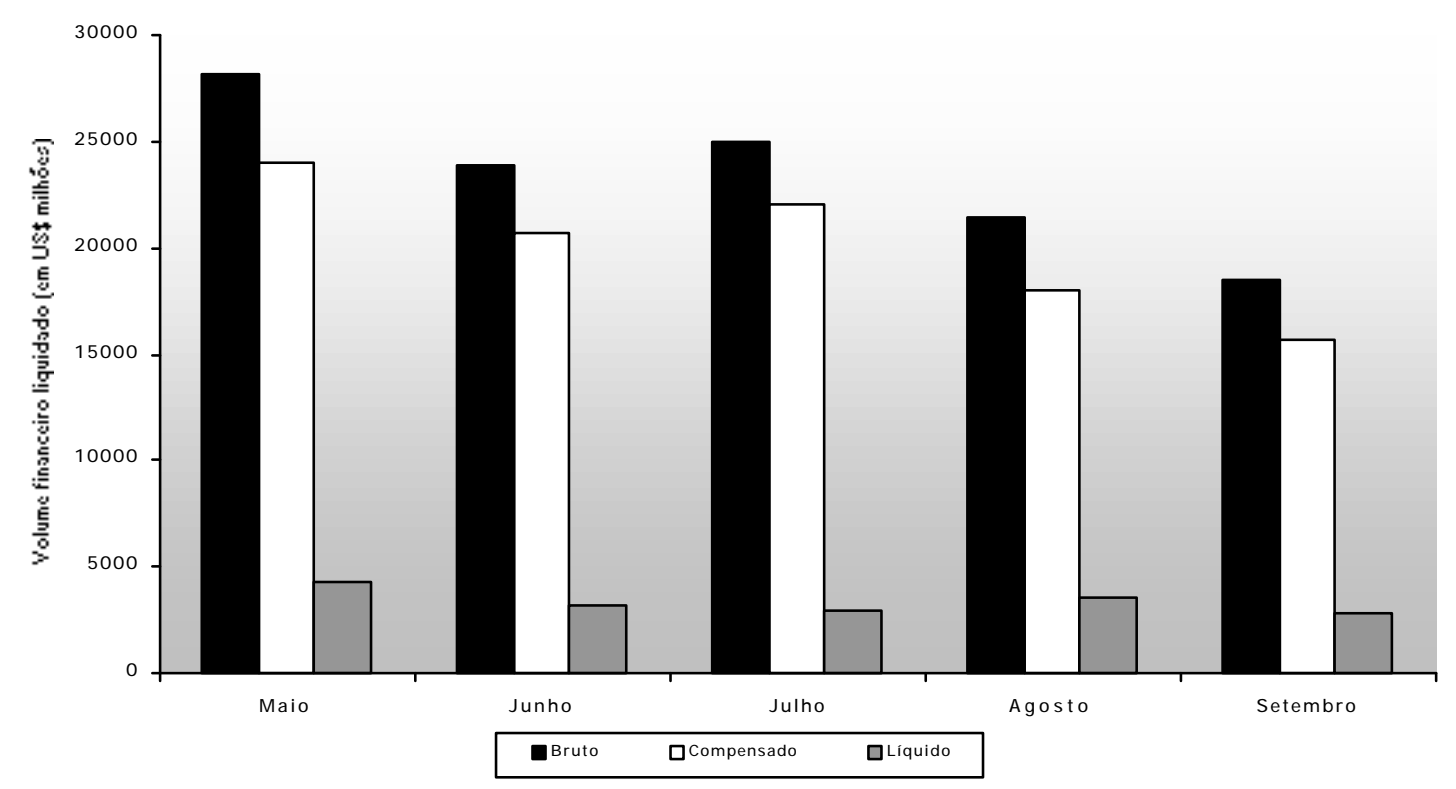

Figura 15 - Volume financeiro mensal liquidado pela Clearing de câmbio entre maio e setembro de 2002.

Fonte: BM\&F (2002b)

Um dos grandes problemas desse mecanismo é a necessidade de recursos para a liquidação do volume contratado. Na hipótese de se realizar a contratação fora do sistema da clearing, o montante de recursos disponíveis pelos bancos deveria ter sido 7 vezes o valor que efetivamente foi liquidado.

A realização das operações fora da clearing obriga os bancos a dispor de reais $(R \$)$ e dólares (US\$) nos montantes brutos contratados para dar curso àliquidação das suas operações de câmbio. No entanto, um banco pode não dispor de recursos em caixa. A solução seria buscar auxílio nas diversas linhas de crédito intradia disponíveis. O problema são os custos inerentes a essas linhas de crédito.

Muitas vezes esses custos não são representados apenas pelos custos objetivos (juros), mas também pelos subjetivos (necessidade de uma garantia). Em situações de crise, um sistema que adota esse princípio de liquidação bruta enfrentaria 
um sério problema de liquidez, refletido diretamente sobre o processo de liquidação das operações de câmbio, vindo a aumentar o risco sistêmico.

A presença da Clearing de câmbio reduziu a necessidade de recursos para liquidar as operações, reduzindo, consequentemente a possibilidade da ocorrência do risco sistêmico do SPB.

\subsection{Banco Central e Clearing de Câmbio}

Apesar de ser responsável por uma parcela significativa das operações no mercado interbancário de câmbio, grande parte das operações realizadas nesse mercado ainda são contratadas e liquidadas fora da clearing de câmbio.

A figura 16 mostra o volume total negociado no mercado interbancário de câmbio negociado pelo BACEN para liquidação em $D+1$. Na mesma figura observa-se a parcela negociada pela Clearing.

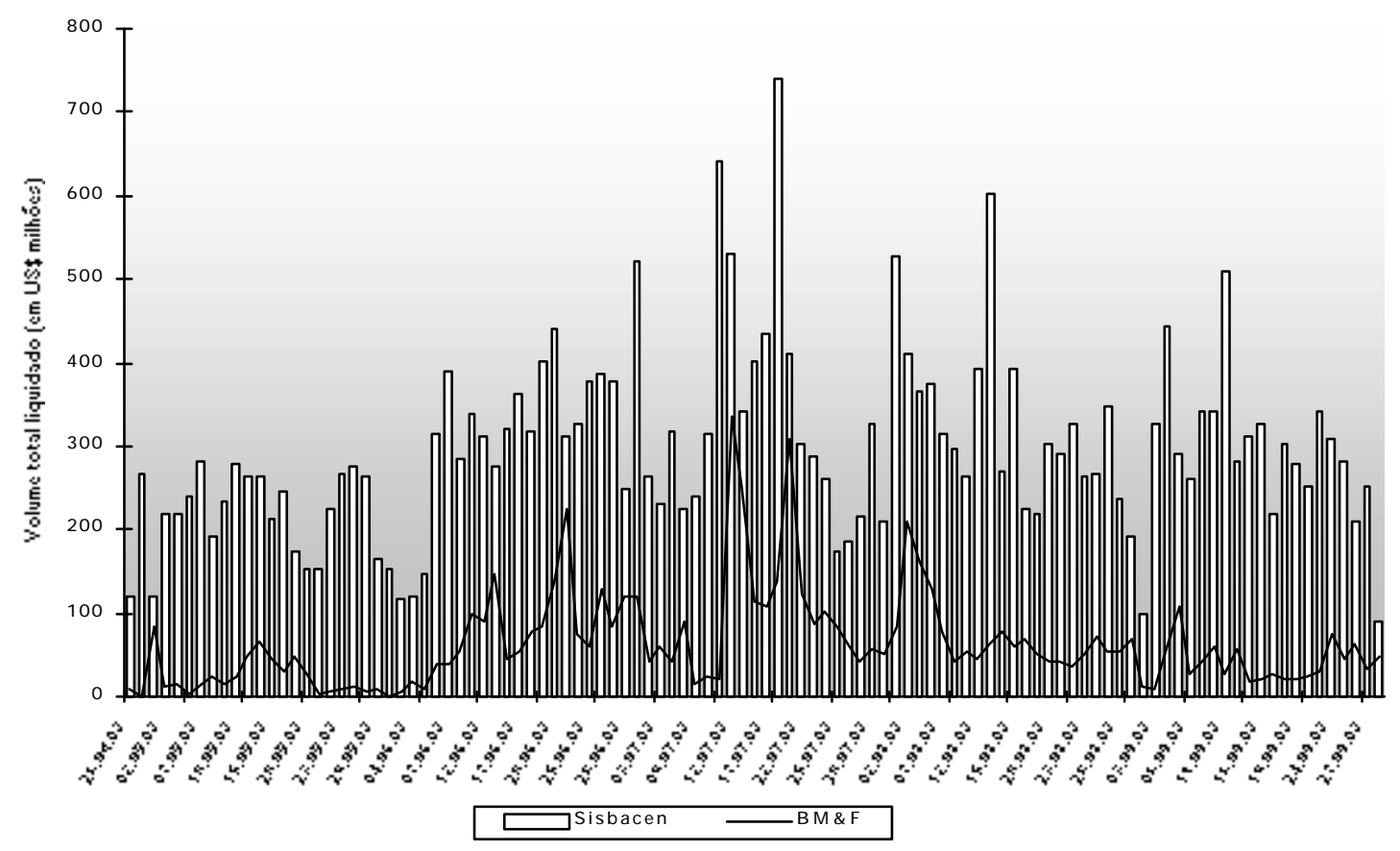

Figura 16 - Volume total do mercado interbancário de câmbio negociado no Sisbacen e na BM\&F para liquidação em D+1 no período de 22/04/2002 a 30/09/2002.

Fonte: BM\&F (2002b) 
Já a figura 17 reflete a participação da clearing de câmbio nas negociações em $D+2$. Essa participação é bem mais significativa e representa um percentual bem maior de todo o volume negociado.

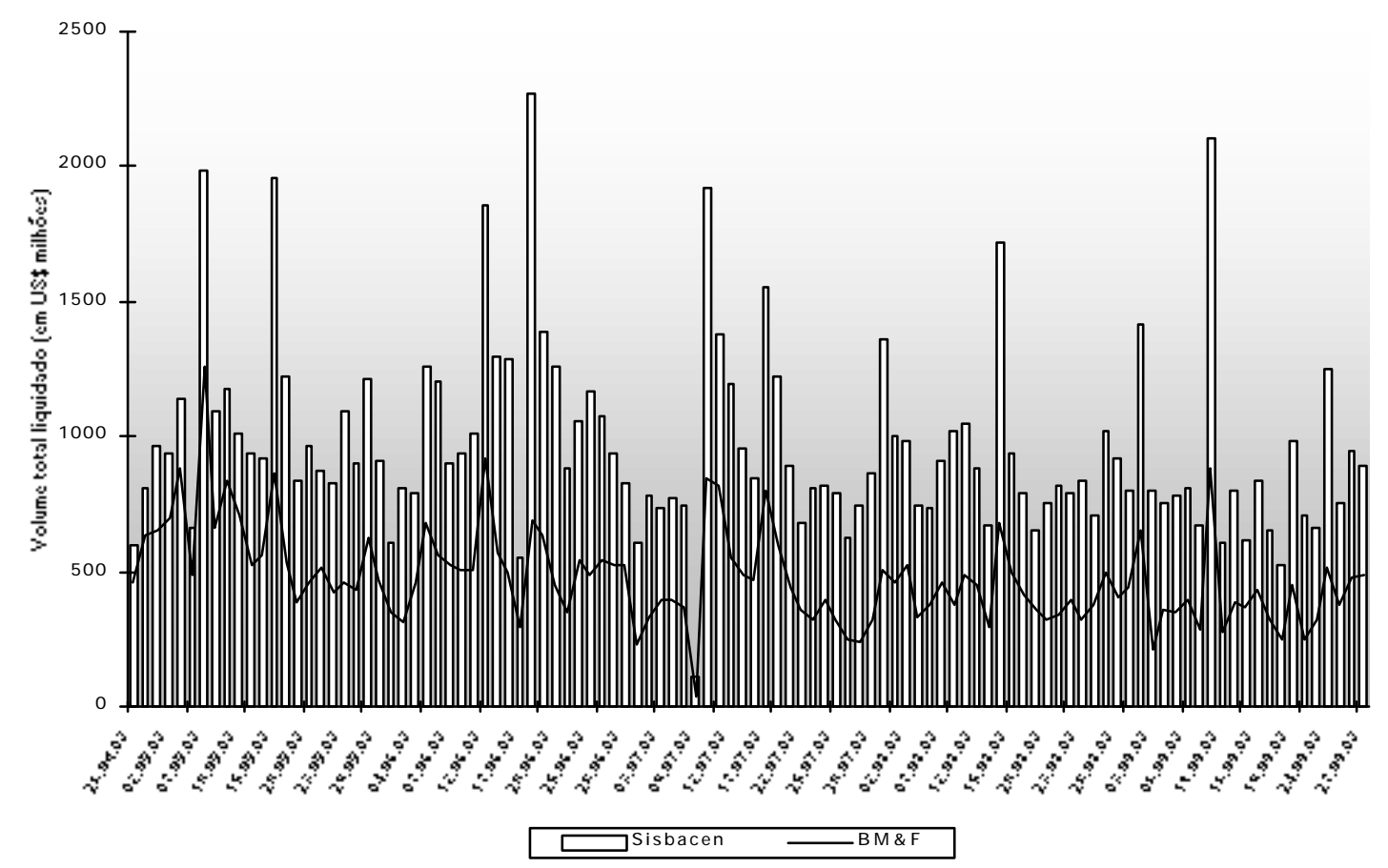

Figura 17 - Volume total do mercado interbancário de câmbio negociado no Sisbacen e na BM\&F para liquidação em D+2 no período de 22/04/2002 a 30/09/2002.

Fonte: BM\&F (2002b)

A figura 18 mostra a participação percentual da Clearing de Câmbio nas negociações do mercado interbancário de câmbio em D+1 e D+2. Verifica-se nesta figura, que a participação da Clearing nas negociações para $D+1$ é bem oscilante. Algumas vezes chegando a atingir quase $80 \%$ e outras vezes caindo a menos de $2 \%$.

Nas negociações para D+2 a volatilidade do número de contratos é menor. Assim que entrou em funcionamento, a Clearing de câmbio passou a ser responsável por cerca de $81 \%$ das negociações do mercado interbancário de câmbio. Esse grande percentual deve-se ao fato da clearing não cobrar dos bancos emolumentos (custo de transações) para as operações vindo a estimular as negociações. 
No entanto, a partir de 10 de maio, a Clearing passou a fazer a cobrança pelas transações realizadas pelo seu sistema. Com isso, o volume de transações reduziu-se a um patamar de aproximadamente $50 \%$.

Para os agentes que diariamente realizam operações no mercado de câmbio, as transações feitas via clearing possuem um custo significativo. Para cada US $\$ 1$ milhão transacionado os bancos devem pagar US $\$ 9,00$ e as instituições financeiras (corretoras) devem pagar US $\$ 6,00$.

Verificando na prática o efeito desse custo, se um banco negociar um montante de US\$ 30 milhões terá um custo operacional de US\$420,00; esse valor corresponde a US $\$ 270,00$ das operações na clearing $(0,0009 \%$ de US $\$ 30$ milhões) e US $\$ 150,00$ das operações de corretagem (600 contratos * $R \$ 0,25 /$ contrato). Se essa transação for realizada no mercado de balcão (por telefone entre os bancos), a despesa fica em US $\$ 150,00$ (pois tem-se apenas o custo da corretagem). O grande problema de uma negociação fora da clearing é a presença do risco de inadimplência na operação, que pode ser alto para os bancos (dependendo do volume negociado e do porte do banco).

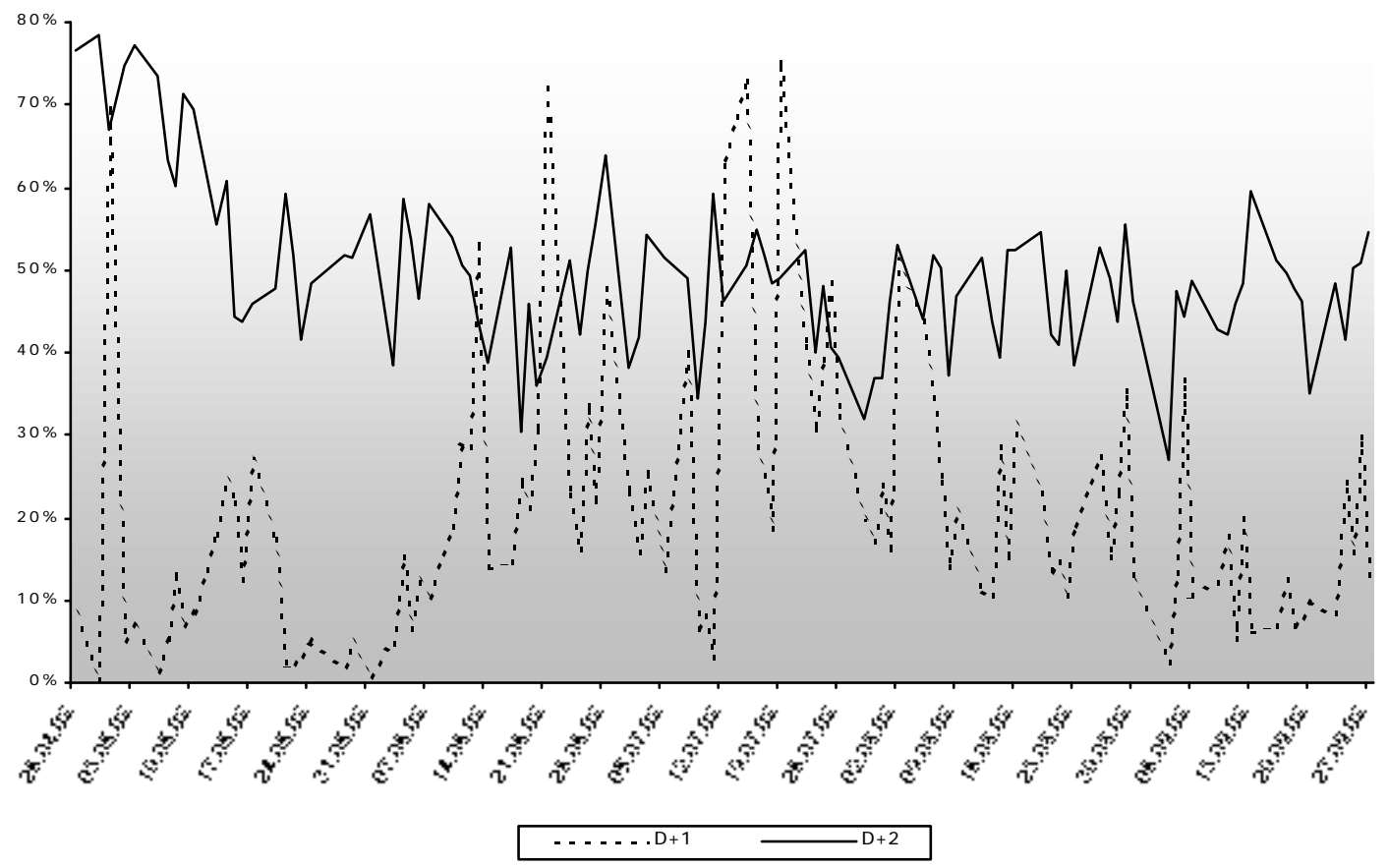

Figura 18 - Participação da Clearing no mercado interbancário de câmbio no período de 26/04/2002 a 30/09/2002.

Fonte: BM\&F (2002b) 
No entanto, a segurança e a garantia da liquidação nas operações realizadas via clearing, faz com que o volume transacionado se situe em torno de $50 \%$ do total negociado pelo mercado interbancário. Mesmo com um custo relativamente elevado, a garantia de liquidação das operações é um estímulo para os bancos realizarem operações através da clearing. 


\section{CONCLUSÕES}

O presente trabalho, inicialmente, destacou o ambiente macroeconômico brasileiro no qual o antigo sistema de pagamentos estava inserido. Algumas das turbulências pelas quais a economia brasileira atravessou durante os anos 90 (entre elas a elevada inflação) foram controladas com a implantação do plano Real. No entanto as instituições financeiras começaram a apresentar dificuldades, crescendo o número de insolvências, motivo pelo qual o governo se viu obrigado a reformular todo o sistema financeiro através dos programas PROER e PROES.

A estrutura do antigo sistema de pagamento brasileiro também foi mostrada, com seus pontos positivos e negativos. Os riscos assumidos pelo BACEN e a forma com que as reservas bancárias eram afetadas pela liquidação foram destacadas, principalmente o risco sistêmico, assumido pelo BACEN e motivo de reformulação de todo o sistema.

No desenvolvimento do trabalho discutiu-se a nova proposta para o sistema de pagamentos, o qual se preocupou principalmente com as mudanças na movimentação de recursos. O processo de criação do Sistema de Transferência de Reservas (que veio auxiliar o BACEN na redução do risco sistêmico) também teve sua importância destacada.

Procurando demonstrar a importância do mercado de câmbio para a economia, o estudo segue discutindo o funcionamento desse mercado e os riscos envolvidos nas suas operações.

Entre os instrumentos de destaque do novo SPB estão as clearings. Estas atuam baseadas na liquidação líquida diferida (DNS) contribuindo para evitar os travamentos decorrentes da interdependência das operações. Primeiramente foram 
apresentados todos os modelos de clearing existentes, expondo-se em seguida 0 projeto da clearing de câmbio da BM\&F.

Foram mostradas as mudanças que o novo sistema trouxe para as pessoas físicas e jurídicas, como a criação da Transferências eletrônica Disponível (TED) para um valor de transação acima de $\mathrm{R} \$ 5$ mil. De todas as clearings existentes no novo SPB, este trabalho centrou-se na clearing de câmbio, expondo inicialmente o seu projeto e em seguida expondo os motivos para o estabelecimento da Transferências Eletrônicas Disponíveis (TED) e o patamar de $\mathrm{R} \$ 5$ mil adotado para essas transações.

No desenvolvimento do trabalho, foi apresentado todo o mecanismo de funcionamento do mercado de câmbio, expondo as formas como estes criam e destroem os meios de pagamentos. Os aspectos operacionais do funcionamento dos contratos de câmbio foram evidenciados, mostrando-se como eram realizadas a contratação, o registro e a liquidação das operações desses mercados.

Vários são os riscos apresentados pelo mercado de câmbio. $O$ trabalho expôs os mais importantes(risco de crédito, de liquidez, operacional, legal e de mercado) e algumas situações em que os mesmos aconteceram. Em seguida foi mostrado como 0 novo SPB seria afetado se não existisse a clearing de câmbio.

Expôs-se o projeto de clearing de câmbio que a BM\&F adotou, com suas características e formas de atuação no mercado. A forma como a Clearing de Câmbio contribuiu para a redução do risco sistêmico também foi discutida.

Quanto às mudanças que aconteceram no mercado de câmbio, verificou-se que as mais fortes ocorreram no mercado interbancário, tanto em quantidade quanto em valor dos contratos. Verifica-se, claramente, uma queda brusca durante o primeiro semestre de 2001 e, desde então, uma estagnação.

Com a implantação no novo SPB, verifica-se uma tendência crescente nas quantidades de mensagens cursadas no STR (giro). Essa quantidade, estagnada até 0 mês de junho, passou a apresentar um comportamento de ascensão a partir desse mês. Destaca-se também a ascensão do volume total de giro e de pagamentos realizadas.

Quanto à Clearing de câmbio, esta tem apresentado um papel importante na redução do risco sistêmico, pois conseguiu reduzir em até $85 \%$ o volume de moeda que efetivamente se transfere de um banco para o outro. Isso foi possível através da adoção do mecanismo de liquidação líquida. 
Um problema que a clearing ainda apresenta é em relação aos seus custos, motivo este que levou à redução do número e do volume de operações. Algumas propostas para a redução da cobrança destes custos já estão sendo estudadas pelo Conselho Deliberativo da BM\&F, formado por vários bancos indicados pela Federação Brasileira de Bancos.

Apesar de alguns bancos ainda fazerem poucos negócios via clearing, tomando por base aqueles que constantemente a utilizam, verifica-se uma grande satisfação com a condução das operações. A redução do tempo necessário para as transferências e a certeza de liquidação são dois pontos favoráveis e estimulantes à realização das negociações na clearing.

Verifica-se que essa nova Câmara de Compensação idealizada na reformulação do SPB, com a finalidade de reduzir o seu risco sistêmico, está cumprindo o seu objetivo, eliminando o risco de principal e amenizando o risco de mercado das operações do setor interbancário de câmbio. Uma estatística ainda mais relevante, quando se fala em risco sistêmico, é a redução da necessidade de recursos para a liquidação das operações, proporcionada pela clearing. Evitando-se, com isso, a manutenção de encaixes ociosos pelos bancos.

Uma questão que está sendo estudada e que irá consolidar ainda mais a clearing como instituição é o lançamento de novos produtos que venham a atender à demanda do mercado financeiro. Entre eles tem-se a possibilidade da realização de operações de compra e venda de dólares com liquidação financeira no mesmo dia, além de D+1 e D+2. Também destaca-se a possibilidade da clearing de câmbio passar a operar outras moedas, como Euro e Yen.

Enfim, a Clearing de Câmbio constitui-se numa peça fundamental do novo SPB, controlado a liquidação do mercado de câmbio e impedindo que o sistema de pagamentos entre em desajuste. 


\section{REFERÊNCIAS BIBLIOGRÁFICAS}

ANDREZO, A.F.; LIMA, I.S. Mercado financeiro: aspectos históricos e conceituais. São Paulo: Pioneira, 1999. 338p.

BANCO CENTRAL DO BRASIL. Projeto de reestruturação do Sistema de Pagamentos Brasileiro. Brasília, 2000a. 47p. Nota Técnica.

BANCO CENTRAL DO BRASIL. Sistemas de pagamentos e riscos: definições básicas. http://www.bcb.gov.br (25 nov. 2000b)

BANCO CENTRAL DO BRASIL. Reestruturação do Sistema de Pagamentos Brasileiro. http://www.bcb.gov.br/htms/infsisp.htm (05 mar. 2001a)

BANCO CENTRAL DO BRASIL. Total de cheques e DOCs no Brasil. http://www.bcb.gob.br (08 out. 2001b)

BANCO CENTRAL DO BRASIL. Documentos do Sistema Financeiro Brasileiro. http://www.bacen.gov.br (26 fev. 2002a)

BANCO CENTRAL DO BRASIL. Tarifas bancárias. http://www.bacen.gov.br (13 ago. 2002b)

BANCO CENTRAL DO BRASIL. Sistema de Pagamentos Brasileiro (SPB) http://www.bcb.gov.br/mPag.htm (29 set. 2002c) 
BANK FOR INTERNATIONAL SETTLEMENTS. Real-time Gross Settlement Systems. http://www.bis.org/publ/index.htm (12 Apr. 2001)

BANK FOR INTERNATIONAL SETTLEMENTS. Core principles for effective banking supervision. http://www.bis.org/publ/bcbs30a.pdf (21 Oct. 2002a)

BANK FOR INTERNATIONAL SETTLEMENTS. Banking crisis in emerging economies: origins and policy options. http://www.bis.org/publ/econ46.pdf (06 Oct. 2002b)

BANK FOR INTERNATIONAL SETTLEMENTS. Report of the Commitee on Netting Schemes of the Central Banks of Group of Ten Countries. http://www.bis.org/publ/cpss04.pdf (15 Apr. 2002c)

BANK FOR INTERNATIONAL SETTLEMENTS. Delivery versus Payment in Securities Settlement Systems. http://www.bis.org/publ/cpss06.pdf (19 May 2002d)

BOLSA DE MERCADORIAS E FUTUROS. Clearing BM\&F: diretrizes básicas dos sistemas de liquidação, garantias, custódia e cadastro. São Paulo, 1996. 18p. Comunicado Externo.

BOLSA DE MERCADORIAS E FUTUROS. Manual de operações: clearing de câmbio. São Paulo, 2002a. 38p.

BOLSA DE MERCADORIAS E FUTUROS. Cotações e mercados http://www.bmf.com.br/pages/Mapasite1/FramelndexClearingCotacoes.htm (02 out. 2002b)

BOLSA DE MERCADORIAS E FUTUROS. Regulamento: clearing de câmbio. São Paulo, 2002c. 16p. 
BOLSA DE MERCADORIAS E FUTUROS. Manual de gerenciamento de risco: clearing de câmbio. São Paulo, 2002d. 47p.

CARVALHO, F.J.C. de; SOUZA, F.E.P. de; SICSÚ, J.; PAULA, L.F.R. de; STUDART, R. Economia monetária e financeira: teoria e prática. Rio de Janeiro: Campus, 2000. 454p.

CHAKRAVORTI, S. Analysis of systemic risk in the Payments System. Basiléia: Suíça, 1996. 28p.

DUARTE JÚNIOR, A.M. Risco: definições, tipos, medição e recomendações para seu gerenciamento. http://www.risktech.com.br/PDFs/RISCO.pdf (04 jul. 2002)

FEDERAÇÃO BRASILEIRA DOS BANCOS. Manual para clientes e bancários. http://www.febraban.org.br/Novo_SPB/index.htm (24 set. 2002)

FORTUNA, E. Mercado financeiro: produtos e serviços. 13.ed. Rio de Janeiro: Qualitymark Editora, 1999. 519p.

FUJIKI, H.; GREEN, E.J.; YAMAZAKI, A. Sharing the risk of settlement failure. Minneapolis: Federal Reserve Bank of Minneapolis, 1999. 27p.

GARÓFALO FILHO, E. Câmbios no Brasil. São Paulo: BM\&F/Cultura, 2000. 253p.

INSTITUTO BRASILEIRO DE GEOGRAFIA E ESTATÍSTICA. Contas Nacionais do Brasil. http://www.ibge.gov.br/ibge/estatistica/economia/contasnacionai/default.shm (23 mar. 2001)

KOTLER, P.; FOX, K.F.A. Marketing estratégico para instituições educacionais. São Paulo: Atlas, 1994. 444p. 
LEE, A.S. A scientific methodology for MIS case studies. MIS Quarterly, v.13, n.1, p.33-50, Mar. 1989.

MAXIMIANO, A.C.A. Introdução àadministração . São Paulo: Atlas, 2000. 546p.

MYERS, M.D. Pesquisa qualitativa em sistemas de informação. MIS Quarterly, v.21, n.2, p.241-242, 1997.

NUNES, F. Indústria e comércio têm estratégias diferentes para receber o SPB. Gazeta Mercantil. São Paulo, 26 abr. 2002.

PROPOSTA da BM\&F para a criação de uma Clearing de câmbio. Resenha BM\&F, n.141, p.15-30, set./out. 2000b.

SANDRONI, P. (Org.). Novo dicionário de economia. 7.ed. São Paulo: Best Seller, 1994. 375p.

SILVA NETO, L.A. Derivativos: definições, emprego e risco. 3.ed. São Paulo: Atlas, 1999. 298p.

SILVERMAN, D. Interpreting qualitative data: methods for analyzing talk, text and interaction. Newbury Park: Sage Publications, 2001. 344p.

SIMONSEN, M.H.; CYSNE, R.P. Macroeconomia. 2.ed. São Paulo: Atlas, 1995. 696p.

SPINOLA, N. O futuro do futuro. São Paulo: Futura, 1998. 315p.

THE MANY facades of BCCl. The Economist, v.320, n.7715, p.81, July 1991.

VAN MAANEN, J. (Ed.). Qualitative methodology. Newbury Park: Sage Publications, 1983. 272p. 
YIN, R.K. Case study research: design and methods. Newbury Park: Sage Publications, 1988. 165p. 
APÊNDICES 


\section{A1 - Glossário}

Chamadas de garantias - É o uso dos ativos entregues à Clearing para cobrir eventuais inadimplências.

D+N - Data negociada no ato da contratação para a liquidação. ( $D+0$ = Liquidação no mesmo dia contratação, D+1 = Liquidação após uma dia útil, D+2 = Liquidação após dois dias úteis)

Day trade - Expressão que significa a realização de uma operação financeira e sua liquidação no mesmo dia, isto é, a compra e a venda de um título por um mesmo operador num mesmo dia. Dessa forma, um ganho ou uma perda são imediatamente obtidos.

DI-Reserva - É a operação de troca de reservas entre os bancos, lançada àconta Reservas Bancárias no próprio dia, por intermédio do Selic, sem lastro em títulos públicos.

Floating - Com inflação elevada, grande parte dos lucros bancários advém do floating nos pagamentos, imposto inflacionário em depósitos não remunerados e transações cambiais, este lucro tende a cair drasticamente com a queda das taxas inflacionárias

Free rider - Também conhecido como "carona". É o incentivo que cada participante tem para elevar a sua própria alavancagem através do aumento do número de contratos.

Gridlock - Situação na qual, numa rede de transferência de valores via cabo, a incapacidade de um banco de saldar suas obrigações em relação a outros bancos pode causar situações semelhantes nestes últimos, provocando um efeito dominó e causando sérios transtornos no mercado financeiro internacional.

Intradia - Operações destinadas a atender necessidades de liquidez de instituição financeira ao longo do dia. 
LFT - Sigla para Letras Financeiras do Tesouro. Trata-se de uma modalidade de empréstimo do Governo brasileiro, na qual ele lança LFTs no mercado para captar recursos. As instituições financeiras interessadas compram essas LFTs (portanto cedendo dinheiro ao Governo) e as resgatam no período e valores previamente combinados. Estes papéis são pós-fixados, rendendo a taxa acumulada no mercado SELIC.

LTN - Sigla para Letras do Tesouro Nacional. Título de dívida pré-fixado usado pelo Tesouro como instrumento de captação de recursos.

Market maker - Agente que, em qualquer mercado, oferece cotação para comprar ou para vender determinado ativo real ou instrumento financeiro. A cotação pela qual ele está disposto a comprar o ativo é denominado de preço de compra e a de venda, preço de venda. Em princípio, o market maker tem como principal fonte de renda o chamado bid-ask spread, isto é, a diferença entre o preço de venda e o preço de compra.

Moral hazard - Expressão que significa excesso de confiança no Banco Central de um país por parte do setor financeiro. Essa credulidade excessiva pode resultar em perdas na medida em que as estimativas de evolução do mercado podem ser superestimadas. Em outras palavras, o aumento do grau de segurança no qual um agente acredita operar pode levá-lo a agir de forma mais ousada e temerária, colocando em risco a estabilidade de uma atividade.

NBCE - Nota do Banco Central Série Especial (NBCE). É o mais famoso dos papéis utilizados pelo BACEN para captar recursos no mercado financeiro. Sua correção está atrelada à variação do dólar comercial e o valor dos juros (a serem pagos a cada seis meses), é definido pelo BACEN quando da emissão, em porcentagem ao ano, aplicado sobre o valor nominativo do título atualizado (com valor trazido para os dias atuais).

Netting - Ou liquidez. É o processo de cálculo do fluxo de caixa entre dois agentes econômicos pelo qual se calcula o pagamento líquido que uma parte deverá fazer àoutra. Esse conceito se aplica ao mercado futuro, em que muitas vezes a margem que um membro de compensação mantém junto àrespectiva câmara de compensação é calculada nessa base líquida: se esse membro de 
compensação tem clientes com uma posição comprada em 1000 contratos de determinado contrato futuro e outros clientes com posição vendida em 900 dos mesmos contratos, a margem seria calculada com base na posição comprada de $100=1000-900$ contratos.

NTND - Notas do Tesouro Nacional com prazo mínimo de 3 meses e juros de $6 \%$ ao ano calculados sobre o valor nominal atualizado.

$\mathbf{R} \$$ - Moeda nacional (Real)

Redesconto - Instrumentos de dívida negociados a curto prazo com desconto, tais como aceites bancários e papéis de curto prazo descontados em um banco em outras palavras, trocados por uma quantia em dinheiro ajustada de acordo com a taxa de juro corrente. O banco então desconta o papel pela Segunda vez, para seu benefício, junto a um outro banco ou a um banco pertencente ao Sistema de Reserva Federal.

Redesconto intradia - Quando a operação de redesconto ocorre no mesmo dia em que foi descontado.

Regulamentação prudencial - São todas as normas e regulamentos estabelecidos pelo Banco Central com o objetivo de estabelecer uma normalidade no sistema financeiro.

Replacement loss - É uma perda financeira que surge devido àsubstituição de uma posição. Ocorre quando um participante necessitar substituir, a preços de mercado, um contrato não honrado por uma contraparte inadimplente.

Reservas Bancárias - Depósitos em espécie que os bancos mantêm no Banco Central tanto para fins de cumprimento de recolhimento compulsório, quanto para efetuar pagamentos interbancários.

Resultado Líquido Multilateral - Corresponde à soma dos resultados financeiros, positivos e negativos, de todas as transações realizadas por determinada instituição com todas as demais instituições com as quais tenha operado.

Second round effect - Ou efeito dominó. Ocorre quando a inadimplência de um participante resulta na inadimplência de suas contrapartes. 
Turnover - Também chamado de giro, é o valor total negociado pelas instituições financeiras em um determinado período. Somando o valor total comprado e o valor total vendido é obtido o turnover.

US\$ - Moeda estrangeira (dólar americano). 


\section{A2 - Lei n. 10214, de 27 de março de 2001}

Dispõe sobre a atuação das câmaras e dos prestadores de serviços de compensação e de liquidação, no âmbito do sistema de pagamentos brasileiro, e dá outras providências

Faço saber que o Presidente da República adotou a Medida Provisória n ․ㅜ 2.115-16, de 2001, que o Congresso Nacional aprovou, e eu Jader Barbalho, Presidente do Senado Federal, para os efeitos do disposto no parágrafo único do art. 62 da Constituição Federal, promulgo a seguinte Lei:

Art. 1ำ Esta Lei regula a atuação das câmaras e dos prestadores de serviços de compensação e de liquidação, no âmbito do sistema de pagamentos brasileiro.

Art. 20 sistema de pagamentos brasileiro de que trata esta Lei compreende as entidades, os sistemas e os procedimentos relacionados com a transferência de fundos e de outros ativos financeiros, ou com o processamento, a compensação e a liquidação de pagamentos em qualquer de suas formas.

Parágrafo único. Integram o sistema de pagamentos brasileiro, além do serviço de compensação de cheques e outros papéis, os seguintes sistemas, na forma de autorização concedida às respectivas câmaras ou prestadores de serviços de compensação e de liquidação, pelo Banco Central do Brasil ou pela Comissão de Valores Mobiliários, em suas áreas de competência:

I - de compensação e liquidação de ordens eletrônicas de débito e de crédito;

II - de transferência de fundos e de outros ativos financeiros;

III - de compensação e de liquidação de operações com títulos e valores mobiliários;

e de futuros; e

IV - de compensação e de liquidação de operações realizadas em bolsas de mercadorias

V - outros, inclusive envolvendo operações com derivativos financeiros, cujas câmaras ou prestadores de serviços tenham sido autorizados na forma deste artigo.

Art. 3ํㅡ É admitida a compensação multilateral de obrigações no âmbito de uma mesma câmara ou prestador de serviços de compensação e de liquidação.

Parágrafo único. Para os efeitos desta Lei, define-se compensação multilateral de obrigações o procedimento destinado àapuração da soma dos resultados bilaterais devedores e credores de cada participante em relação aos demais.

Art. 4ํㅗ Nos sistemas em que o volume e a natureza dos negócios, a critério do Banco Central do Brasil, forem capazes de oferecer risco à solidez e ao normal funcionamento do sistema financeiro, as câmaras e os prestadores de serviços de compensação e de liquidação assumirão, sem prejuízo de obrigações decorrentes de lei, regulamento ou contrato, em relação a cada participante, a posição de parte contratante, para fins de liquidação das obrigações, realizada por intermédio da câmara ou prestador de serviços.

$\S 1^{\circ}$ As câmaras e os prestadores de serviços de compensação e de liquidação não respondem pelo adimplemento das obrigações originárias do emissor, de resgatar o principal e os acessórios de seus títulos e valores mobiliários objeto de compensação e de liquidação.

$\S 2^{\circ}$ Os sistemas de que trata o caput deverão contar com mecanismos e salvaguardas que permitam às câmaras e aos prestadores de serviços de compensação e de liquidação assegurar a certeza da liquidação das operações neles compensadas e liquidadas. 
$\S 3^{\circ}$ Os mecanismos e as salvaguardas de que trata o parágrafo anterior compreendem, dentre outros, dispositivos de segurança adequados e regras de controle de riscos, de contingências, de compartilhamento de perdas entre os participantes e de execução direta de posições em custódia, de contratos e de garantias aportadas pelos participantes.

Art. $5^{\circ}$ Sem prejuízo do disposto no $\S 3^{\circ}$ do artigo anterior, as câmaras e os prestadores de serviços de compensação e de liquidação responsáveis por um ou mais ambientes sistemicamente importantes deverão, obedecida a regulamentação baixada pelo Banco Central do Brasil, separar patrimônio especial, formado por bens e direitos necessários a garantir exclusivamente o cumprimento das obrigações existentes em cada um dos sistemas que estiverem operando

$\S 1^{\circ}$ Os bens e direitos integrantes do patrimônio especial de que trata o caput, bem como seus frutos e rendimentos, não se comunicarão com o patrimônio geral ou outros patrimônios especiais da mesma câmara ou prestador de serviços de compensação e de liquidação, e não poderão ser utilizados para realizar ou garantir o cumprimento de qualquer obrigação assumida pela câmara ou prestador de serviços de compensação e de liquidação em sistema estranho àquele ao qual se vinculam.

$\S 2^{\circ}$ Os atos de constituição do patrimônio separado, com a respectiva destinação, serão objeto de averbação ou registro, na forma da lei ou do regulamento.

Art. $\sigma^{0}$ Os bens e direitos integrantes do patrimônio especial, bem como aqueles oferecidos em garantia pelos participantes, são impenhoráveis, e não poderão ser objeto de arresto, seqüestro, busca e apreensão ou qualquer outro ato de constrição judicial, exceto para o cumprimento das obrigações assumidas pela própria câmara ou prestador de serviços de compensação e de liquidação na qualidade de parte contratante, nos termos do disposto no caput do art. $4^{\circ} \stackrel{\text { desta Lei. }}{ }$

Art. $7^{\circ}$ Os regimes de insolvência civil, concordata, intervenção, falência ou liquidação extrajudicial, a que seja submetido qualquer participante, não afetarão o adimplemento de suas obrigações, assumidas no âmbito das câmaras ou prestadores de serviços de compensação e de liquidação, que serão ultimadas e liquidadas pela câmara ou prestador de serviços, na forma de seus regulamentos.

Parágrafo único. O produto da realização das garantias prestadas pelo participante submetido aos regimes de que trata o caput, assim como os títulos, valores mobiliários e quaisquer outros seus ativos, objeto de compensação ou liquidação, serão destinados à liquidação das obrigações assumidas no âmbito das câmaras ou prestadores de serviços.

Art. $8^{\circ}$ Nas hipóteses de que trata o artigo anterior, ou quando verificada a inadimplência de qualquer participante de um sistema, a liquidação das obrigações, observado o disposto nos regulamentos e procedimentos das câmaras ou prestadores de serviços de compensação e de liquidação, dar-se-á: movimentação financeira; $e$

I - com a tradição dos ativos negociados ou a transferência dos recursos, no caso de

II - com a entrega do produto da realização das garantias e com a utilização dos mecanismos e salvaguardas de que tratam os $\S \S 2^{\circ}$ e $3^{\circ}$ do art. $4^{\circ}$, quando inexistentes ou insuficientes os ativos negociados ou os recursos a transferir.

Parágrafo único. Se, após adotadas as providências de que tratam os incisos I e II, houver saldo positivo, será ele transferido ao participante, integrando a respectiva massa, se for o caso, e se houver saldo negativo, constituirá ele crédito da câmara ou do prestador de serviços de compensação e de liquidação contra o participante.

Art. $9 \mathrm{~A}$ infração às normas legais e regulamentares que regem o sistema de pagamentos sujeita as câmaras e os prestadores de serviços de compensação e de liquidação, seus administradores e membros de conselhos fiscais, consultivos e assemelhados às penalidades previstas:

do Brasil;

I - no art. 44 da Lei n 4.595, de 31 de dezembro de 1964, aplicáveis pelo Banco Central 
Mobiliários.

II - n 6.385, de 7 de dezembro de 1976, aplicáveis pela Comissão de Valores

Parágrafo único. Das decisões proferidas pelo Banco Central do Brasil e pela Comissão de Valores Mobiliários, com fundamento neste artigo, caberá recurso, sem efeito suspensivo, para 0 Conselho de Recursos do Sistema Financeiro Nacional, no prazo de quinze dias.

Art. 10. O Conselho Monetário Nacional, o Banco Central do Brasil e a Comissão de Valores Mobiliários, nas suas respectivas esferas de competência, baixarão as normas e instruções necessárias ao cumprimento desta Lei.

Art. 11. Ficam convalidados os atos praticados com base na Medida Provisória n².11515 , de 26 de janeiro de 2001.

Art. 12. Esta Lei entra em vigor na data de sua publicação.

Congresso Nacional, 27 de março de 2001;

$180^{\circ}$ da Independência e $113^{\circ}$ da República.

Senador JADER BARBALHO Presidente do Congresso Nacional

Esta versão não se reveste da legalidade jurídica conferida ao texto original publicado no D.O.U. de 28.3.2001 (edição extra) 